\title{
AGEING E ALTERAÇÃO DA REGIÃO OVERLAP:GAP DO COLÁGENO TIPO I - REPERCUSSÃO SOBRE A MINERALIZAÇÃO E SEU PAPEL NA OSTEOPOROSE
}

\section{MARINA GARCIA BRAGA ALVES}

Dissertação de mestrado apresentada ao Programa de Pós-Graduação Interunidades Bioengenharia - Escola de Engenharia de São Carlos/ Faculdade de Medicina de Ribeirão Preto/ Instituto de Química de São Carlos da Universidade de São Paulo, como parte dos requisitos para obtenção do título de Mestre em Bioengenharia.

Área de concentração: Bioengenharia

ORIENTADOR: Prof. Dr. Gilberto Goissis 


\section{AGRADECIMENTOS}

Primeiramente, gostaria de agradecer a DEUS, essa força maior que todos nós e a quem entrego verdadeiramente a minha vida, pois tenho certeza que Ele nunca me deixou só, conduzindo meus conhecimentos, me dando forças para continuar.

Agradeço também aos meus pais que sempre me apoiaram e acreditaram em mim, ao meu marido pela paciência e companheirismo nos momentos difíceis e a minha filha Yasmin, que embora tão pequena, já me ensina muitas coisas como ser persistente e continuar caminhando...

Finalmente agradeço ao Prof. Dr. Gilberto Goissis e sua equipe pela atenção e apoio durante esse processo de orientação. Muito obrigada pela paciência, e pelo tempo dispensado na contribuição do meu crescimento científico e intelectual. 


\section{RESUMO}

ALVES, M. G. B. (2006) Ageing e alteração da região Overlap:Gap do colágeno Tipo I repercussão sobre a mineralização e seu papel na osteoporose Dissertação (Mestrado) Escola de Engenharia de São Carlos /Faculdade de Medicina de Ribeirão Preto /Instituto de Química de São Carlos, Universidade de São Paulo, São Carlos, 2006.

Osteoporose é a doença osteometabólica mais comum na população idosa. É definida como redução difusa da qualidade óssea que surge por um desbalanço entre a reabsorção e a formação óssea. Vários fatores etiológicos acontecem juntos levando à redução das proteínas ósseas, entre eles: deficiência hormonal, senilidade, subnutrição e imobilização. Um fator etiológico que, além dos processos de mutação, leva a alteração da estrutura do colágeno no processo de envelhecimento é o "ageing", que se caracterizado por mudanças estruturais na Matriz Extracelular e virtualmente atinge todos os tecidos e sistemas orgânicos. Mudanças nas ligações cruzadas têm sido considerada como o papel principal do "ageing" e essas ocorrem através de 2 principais maneiras: a primeira é um processo enzimático pela ação da lisil oxidase e a segunda é um processo não-enzimático e recebe o nome de Glicação. Essa ultima envolve reação da glicose com Arginina (Arg) e Lisina (Lys) sendo a principal causa de disfunção dos tecidos colágeno na idade avançada. No "ageing" há hidroxilação da Lisina (Lys) levando modificação nas ligações cruzadas, o que gera uma estrutura de colágeno alterada. Além disso, a alteração em especial da Arginina (Arg) afeta a crucial interação célula-matriz envolvendo "motifs" como o RGD (Arg-Gly-Asp), o que altera a mineralização e remodelagem óssea. Essas modificações envolvendo o intervalo 70-110 do período D do colágeno Tipo I, que corresponde a interface Overlap:Gap tem uma séria repercussão, pois segundo o modelo de mineralização, qualquer variação de carga nesse local afeta a interação com a fosfoforina, uma proteína ácida que parece ser o gatilho para o processo de mineralização da dentina, e que também, de alguma forma, deve ocorrer no tecido ósseo. Assim, em um colágeno bioquimicamente modificado pelas reações do "ageing" leva, entre outras coisas, a uma alteração na mineralização, e essa alteração seria mais um fator a ser considerado no estudo da osteoporose.

Palavras-chave: Ageing, colágeno Tipo I, mineralização, osteoporose 


\section{ASTRACT}

ALVES, M. G. B. Ageing and the change of Type I collagen juncion Overlap:Gap - its mineralization influence and its action in the osteoporosis São Carlos, 2006. 80p. Essay (Master's Degree) - São Carlos Engeneering School/ Ribeirão Preto Medicine College/ São Carlos Chemical Institute, São Paulo University, São Carlos, 2006.

Osteoporosis is the most commom osteometabolic disease in the elderly. It's definied like difuse reduction of bone density that arouses from a delicate debalance between bone reabsorption and formation. Several etiologic factors happens together and they result in the reduction of bone proteins, like hormonal deficiency, senility, bad nutrition and imobilization. Another etiologic factor that causes the collagen struture modification in old age it's "ageing", characterized for structure modification on extracelular matrix and virtually affect all tissue and organic system. Modification on cross-link have been considered like main reason of 'ageing" and these modifications occur through two main ways: the first one is an enzimatic process for the lysil oxidase action and the second is a non-enzimatic process denominated glycation. The last process involve the glucose reaction with arginine (Arg) and lysine (Lys) being the main cause of the collagen tissue disfunction in advanced age. In "ageing" process there is a lysine (Lys) hidroxilation modification the cross-link what results a fragilized collagen structure. Besides, the special modification of arginine (Arg) affects the crucial interaction of the cell matrix involving motifs like RGD (Arg-Gly-Asp) and it alters the bone mineralization and remodeling. This modification around the interval 70-110 of period collagen type I, that corresponds to the interface Overlap:Gap has a serious repercussion, because according to the mineralization standard, which charge alteration in this place affects the interaction with phosphoforin an acid protein that seems to be the responsible to start the mineralization process in dentin and in the same way it may occur in the bone tissue. In this manners, in a biochemically modified collagen causes, among other things, to a mineralization alteration, and this alteration was been one more factor to be considered in the osteoporosis study.

Key-words: Ageing, collagen Type I, mineralization, osteoporosis 


\section{LISTA DE FIGURAS}

Figura 1. Perspectiva da população idosa no Brasil em ambos os sexos

Figura 2. Esquema representando a perda óssea na osteoporose Tipo I e Tipo II

Figura 3. Gráfico relacionando perda óssea, idade e sexo no osso trabecular e cortical

Figura 4. Esquema de fatores do determinismo para osteoporose

Figura 5. Esquema representativo do fêmur humano - osso cortical e trabecular

Figura 6. Esquema representativo da localização das células ósseas

Figura 7. Microestrutura do colágeno Tipo I

Figura 8. Micrografia de Microscopia Eletrônica de Transmissão de fibras de colágeno do Tipo I obtida após impregnação de acetato de uranila e fosfotungstato de amônio:

(a) Impregnação negativa e (b) Impregnação positiva

Figura 9. Comparação de Microscopia Eletrônica de Transmissão com Modelo Pentafibrilar de Smith: (a) Formação de periodicidade e subperiodicidade do colágeno Tipo I ; (b) figura representando Modelo Pentafibrilar de Smith

Figura 10. Processo de fibrilogênese do colágeno

Figura 11. Esquema da ação do osteoblasto e osteoclasto na remodelagem óssea

Figura 12. Representação esquemática do efeito elétrico na remodelagem

Figura 13. Micrografia de Microscopia Eletrônica de Transmissão de osteoblasto ativo produzindo fibras de colágeno mineralizada após 14 dias de implantação de matriz tridimensional de colágeno

Figura 14. Esquema da transdução de sinais provenientes da Matriz Extracelular para o interior da célula

Figura 15. Modelo para alterações da atividade celular do fibroblasto em função de tensões aplicadas sobre a Matriz Extracelular

Figura 16. Estruturas químicas dos aminoácidos: Acido Aspártico, Acido Glutâmico, Asparagina, Glutamina, Lisina e Arginina

Figura 17. Esquema dos locais de formação de ligações cruzadas em matrizes colagênicas no "ageing"

Figura 18. Esquema químico da Isomerização 
Figura 19. Esquema químico do processo enzimático de formação de ligação cruzada

Figura 20. Esquema químico da Glicação

Figura 21. Resultante da distribuição de carga do período D do colágeno levando-se em consideração a distribuição dos aminoácidos ácidos e básicos. Seta: indicação da diminuição da basicidade da interface Overlap:Gap

Figura 22. Distribuição de aminoácidos hidrofóbicos e a somatória de Ácidos Aspártico e Glutâmico no período D

Figura 23. Modelo para mineralização in vitro de matrizes de colágeno polianiônico com $46 \pm 12$ cargas adicionais negativas, preparadas por hidrólises de cadeias laterais de resíduos de Asparagina e Glutamina presentes na estrutura colagênica

Figura 24. Modelo Pentafibrilar de Smith para a reorganização fibrilar do colágeno baseado no deslocamento da molécula de colágeno de $1 / 4$ de seu comprimento

Figura 25. Esquema representativo da distribuição dos aminoácidos no período D quando cinco moléculas de colágeno são dispostas alternadamente de 1/4 de seu comprimento

Figura 26. Distribuição da soma dos resíduos ácidos e básicos no período D da microfibrila do colágeno do Tipo I

Figura 27. Distribuição no período D da microfibrila do colágeno do Tipo I da soma de resíduos de Ácido Aspártico e Ácido Glutâmico

Figura 28. Distribuição do Ácido Glutâmico (A) e Ácido Aspártico (B) no período D

Figura 29. Distribuição de aminoácidos: Ácido Glutâmico (A) e Ácido Aspártico (B) nas cadeias $\alpha$ que formam o período $\mathrm{D}$ das microfibrilas de colágeno

Figura 30. Distribuição da soma dos resíduos básicos no período D da microfibrila do colágeno Tipo I

Figura 31. Distribuição de Lisina (A) e Arginina (B) no período D

Figura 32. Distribuição de aminoácidos básicos nas cadeias $\alpha$ que formam o período D das microfibrilas de colágeno

Figura 33. Distribuição no período D do colágeno do Tipo I, dos aminoácidos polares carregados e da somatória dos aminoácidos hidrofóbicos (Valina, Leucina, Isoleucina, Metionina e Fenilalanina)

Figura 34. Distribuição da somatória dos valores numéricos relativos ao Overlap e Gap para os resíduos Valina, Leucina, Isoleucina, Metionina e Fenilalanina

Figura 35. Comparação da distribuição da soma dos resíduos hidrofóbicos (A) e Ácido Aspártico (B) nas cadeias $\alpha$ que formam o período D das microfibrilas do colágeno 


\section{LISTA DE TABELAS}

Tabela 1. Condições clínicas associadas com defeitos moleculares de proteínas estruturais

Tabela 2. Estrutura primária das cadeias $\alpha_{1}$ e $\alpha_{2}$ do colágeno Tipo I

Tabela 3. Distribuição dos aminoácidos ácidos, básicos, hidrofóbicos e aminas na região 70-110 do período D do colágeno Tipo I, avaliados separadamente no Overlap, no Gap e também na somatória total 


\section{LISTA DE ABREVIATURAS E SÍMBOLOS}

$\begin{array}{ll}\text { Arg } & \text { Arginina } \\ \text { Asn } & \text { Asparagina } \\ \text { Asp } & \text { Ácido Aspártico } \\ \text { BMPs } & \text { Proteinas morfogeneticas ósseas } \\ \text { BSP } & \text { Sialoproteina Bovina } \\ \text { DMP } 1 & \text { Matriz proteica dentinada } \\ \text { DMP } & \text { Matriz proteica dentinada } \\ \text { DPP } & \text { Fosfoproteína dentinária } \\ \text { DSP } & \text { Sialoproteína dentinária } \\ \text { DSPP } & \text { Fosfoproteína siálica dentinária } \\ \text { Gln } & \text { Glutamina } \\ \text { Glu } & \text { Ácido Glutâmico } \\ \text { Gly } & \text { Glicina } \\ \text { HA } & \text { Hidroxiapatita } \\ \text { His } & \text { Histidina } \\ \text { Hyl } & \text { Hidroxilisina } \\ \text { Hyp } & \text { Hidroxiprolina } \\ \text { IBGE } & \text { Instituto Brasileiro de Geografia e Estatística } \\ \text { IGF } & \text { Fator de crescimento tipo insulínico } \\ \text { Leu } & \text { Leucina } \\ \text { Lys } & \text { Lisina } \\ \text { MEC } & \text { Matriz Extracelular } \\ \text { MET } & \text { Microscopia Eletrônica de transmissão } \\ \text { OMS } & \text { Organização Mundial da Saúde } \\ \text { P } & \text { Fósforo } \\ \text { pH } & \text { Potencial de Hidrogênio } \\ \text { pI } & \text { pH do ponto isoelétrico } \\ \text { Pro } & \text { Prolina } \\ \text { PTA } & \text { Fosfotungstato de amônio } \\ \text { PTH } & \text { Hormônio da Paratireóide } \\ \text { RGD } & \text { Arginina-Lisina- Acido Aspártico } \\ \text { RNAm } & \text { Acido ribonucleico mensageiro } \\ \text { Ser } & \text { Serina } \\ \text { TGF- } 3 & \text { Fator de crescimento transformante } \beta \\ \text { Thr } & \text { Treonina } \\ \text { Tyr } & \text { Tirosina } \\ \text { UA } & \text { Acetato de uranila } \\ \text { WHO } & \text { World Health Organization } \\ & \end{array}$


RESUMO

\section{ABSTRACT}

LISTA DE FIGURAS

LISTA DE TABELAS

LISTA DE ABREVIATURAS E SÍMBOLOS

1 INTRODUÇÃO

$\begin{array}{ll}\text { 1.1 Osteoporose } & 15\end{array}$

1.2 Tecido ósseo 23

1.2.1 Forma e função 23

1.2.2 Composição do tecido ósseo 25

1.2.2.1 Células ósseas 26

$\begin{array}{ll}1.2 .2 .2 \text { Colágeno } & 29\end{array}$

1.2.2.2.1 Estrutura do colágeno Tipo I 30

1.2.2.2.2 Função do colágeno Tipo I 34

$\begin{array}{ll}\text { 1.2.2.3 Proteinas não-colagênicas } & 35\end{array}$

1.2.3 Dinamica do tecido ósseo - Remodelagem 39

1.3 Biomineralização 43

1.4 Adesão celular e a transducção de sinal 45

1.5 Ageing $\quad 49$

1.5.1 Processo enzimático de formação de ligações cruzadas 52

1.5.2 Processo não-enzimático de formação de ligações cruzadas 53

1.5.3 Alterações do "ageing" no tecido ósseo e sua repercussão na osteoporose 55

2 OBJETIVOS

3 MATERIAL E MÉTODO $\quad 60$

3.1 Descrição do mapa de distribuição da estrutura primária das cadeias alfa que formam a microfibrila de acordo com o modelo de Smith 60

4 RESULTADOS E DISCUSSÃO

4.1 Modelo para a mineralização do colágeno 67 
4.3 Distribuição de aminoácidos básicos, ácidos e hidrofóbicos no período D e nas cadeias alfa

4.3.1 Aminoácidos ácidos

4.3.2 Aminoácidos básicos

4.3.3 Aminoácidos hidrofóbicos

4.4 Características estruturais do intervalo 70-110 no período $\mathrm{D}$ do colágeno Tipo I

5 CONCLUSÃO

REFERÊNCIAS BIBLIOGRÁFICAS

GLOSSÁRIO 


\section{INTRODUÇÃO}

No corpo humano, $20 \%$ da massa total é composta por proteína; dentre as proteínas existentes, a mais abundante é o colágeno, perfazendo 30\% do total ou mais. Dentre os vários tipos existentes, o colágeno Tipo I representa $90 \%$ do total de colágeno no corpo humano (DI LULLO et al., 2001). É por essa importância que ele passa a ser o assunto de várias pesquisas na atualidade, na tentativa de desvendar muitas patologias e desordens teciduais, investigando sua estrutura e composição de aminoácidos, moléculas com as quais interage e suas mutações.

Segundo Vieira et al. (1995, p.346), a expressão doença do colágeno deve ser aplicada apenas às condições clínicas, nas quais defeitos bioquímicos específicos (estruturais e metabólicos) possam ser demonstrados em colágeno, elastina e substância intercelular amorfa. Algumas dessas doenças podem ser descritas na Tabela 1.

Tabela 1. Condições clínicas associadas com defeitos moleculares de proteínas estruturais.

Fonte: VIEIRA et al. (1995)

\begin{tabular}{ll}
\hline Condição clínica & Anormalidade Molecular \\
\hline Earfan & $\begin{array}{l}\text { Defeito na ligação cruzada de colágeno e/ou elastina } \\
\text { Produção defeituosa de colágeno IV } \\
\text { Acúmulo de procolágeno nos tecidos } \\
\text { Deficiência de lisil-oxidade } \\
\text { Possível deficiência de fibronectina } \\
\text { Baixa atividade de lisil-oxidase; baixos níveis de cobre sérico }\end{array}$ \\
$\begin{array}{l}\text { Osteogênese } \\
\text { Imperfeita }\end{array}$ & $\begin{array}{l}\text { Decréscimo na síntese e secreção de colágeno I } \\
\text { Cutis laxa }\end{array}$ \\
$\begin{array}{l}\text { Alterações microscópicas de fibras elásticas e colágenas ainda sem } \\
\text { compressão de patologia molecular } \\
\text { elástico }\end{array}$ & $\begin{array}{l}\text { Alterações de fibras elásticas sem compreensão da patologia } \\
\text { molecular }\end{array}$ \\
\hline
\end{tabular}


Atualmente, segundo o Instituto Brasileiro de Geografia e Estatística. (IBGE), no Brasil, a população idosa é o segmento que está em crescimento contínuo (Figura 1); dessa forma, a patologias que levam a alteração do tecido conjuntivo, em especial do colágeno, comparativamente também tornam-se mais freqüentemente. Dessas desordens encontradas, a mais comum e que representa a maior causa de morbidade e mortalidade na velhice é a osteoporose.

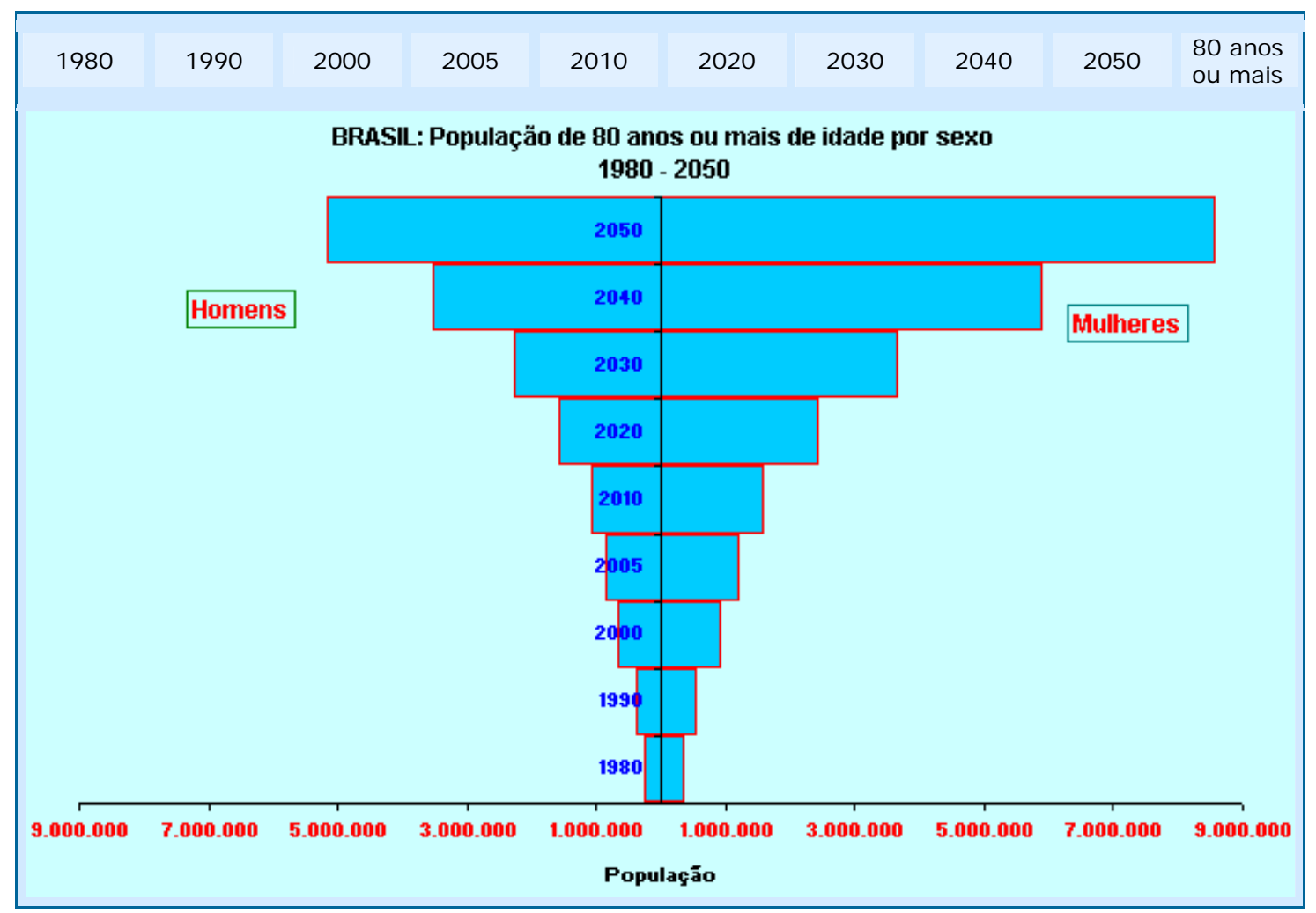

Figura 1. Perspectiva da população idosa no Brasil em ambos os sexos Fonte: INSTITUTO BRASILEIRO DE GEOGRAFIA E ESTATÍSTICA (2006)

Segundo projeções e levantamentos isolados da Consensus Proposal ${ }^{1}$ (1995 apud PAIVA, 2003), no Brasil, estima-se que a osteoporose acometa cerca de $20 \%$ das mulheres brasileiras com mais de 50 anos. Contudo, esses dados mostram-se melhor representados pelo

\footnotetext{
1 NATIONAL CONSENSUS PROPOSAL. OSTEOPOROSIS (1995) - Basic diagnosis and therapeutic elements. Suppl: 7-18 apud In: PAIVA L.C. et al. (2003) Prevalência de Osteoporose em mulheres na Pósmenopausa e Associação com Fatores Clínicos e Reprodutivos. Revista Brasileira de Ginecologia e Obstetrícia, v.25, n.7, p.507-512, Agosto.
} 
elevado número de fraturas conseqüentes da osteoporose, em que cerca de $20 \%$ a $25 \%$ destas localizam-se no fêmur. Segundo Cooper et al. (1992), a fratura de fêmur representa a terceira causa de internação hospitalar e a segunda causa de óbito entre a população feminina americana e européia com mais de 50 anos. Considera-se atualmente no Brasil que as fraturas de fêmur conseqüentes da osteoporose atinjam mais de 8 milhões de pessoas (DATASUS, 2005).

\subsection{Osteoporose}

Sendo a osteoporose a doença osteometabólica mais comum no Brasil, essas fraturas têm importância na sociedade, considerando o envelhecimento progressivo de sua população. Com isso, espera-se o aumento nos transtornos da densidade e da estrutura óssea que atualmente alcança mais de 1,3 milhões de pessoas (DATASUS, 2005).

De acordo com a definição da Organização Mundial da Saúde (OMS), a osteoporose é caracterizada pela diminuição e deterioração da microarquitetura do tecido ósseo, conduzindo a um aumento da sua fragilidade e a um conseqüente aumento do risco de fraturas (WORLD HELTH ORGANIZATION STUDY GROUP,1994). A osteoporose resulta da progressiva perda de massa óssea e deterioração da microarquitetura do tecido ósseo, com estreitamento trabecular e diminuição da resistência óssea, levando a maior suscetibilidade às fraturas, mesmo com traumas de pequena intensidade (NOTELOVITZ, 2001). A doença afeta tanto o esqueleto axial como o apendicular, ocorrendo em ossos corticais e trabeculares, sendo mais freqüente nesses últimos. Acomete principalmente a população feminina, de forma que a incidência de fratura vertebral é 4-8 vezes maior na mulher quando comparada ao homem (CUMMINGS et al., 1985). 
Essa redução difusa da densidade mineral óssea é decorrente de um desbalanço entre as fases de reabsorção e formação óssea, que pode ser resultante de osteoclastos hiperativos e/ou de atividade osteoblástica reduzida.

Quando não há outra condição médica presente, as mulheres são ditas portadoras de osteoporose primária, a qual pode ser dividida em (Figura 2):

- Tipo I: em que a perda óssea ocorre principalmente no compartimento trabecular e é relacionada intimamente à perda da função ovariana que ocorre após a menopausa; observa-se alta reabsorção óssea decorrente de atividade osteoclástica acelerada.

- Tipo II: em que a perda óssea envolve o osso cortical e corresponde à osteoporose senil ou de involução, pois decorre do processo fisiológico de envelhecimento. É de reabsorção óssea normal ou ligeiramente aumentada, associada à atividade osteoblástica diminuída (NOTELOVITZ, 2001).

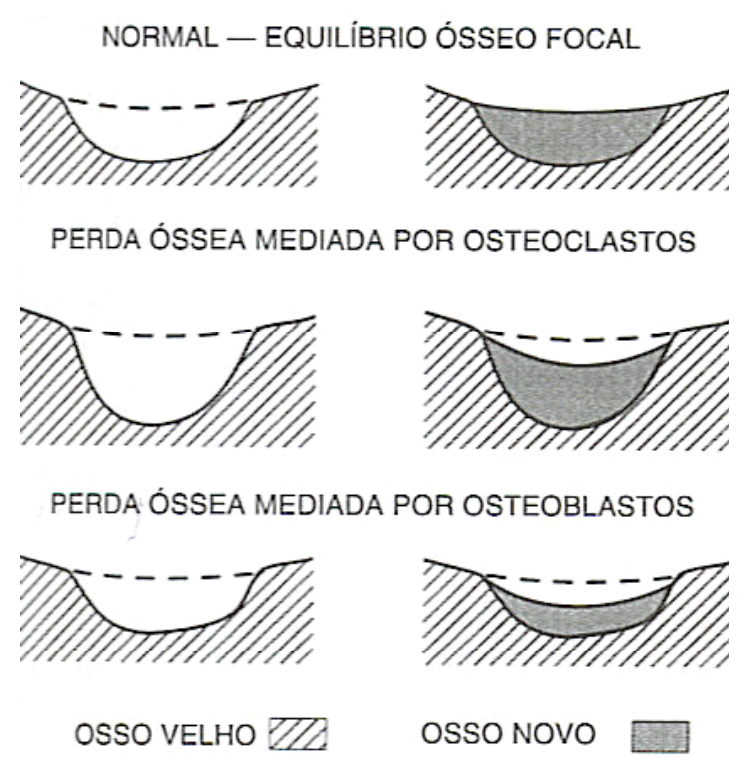

Figura 2. Esquema representando a perda óssea na osteoporose Tipo I e Tipo II Fonte: NOTELOVITZ, M. (2001)

Casos de osteoporose secundária a outras patologias podem resultar em distúrbio da absorção intestinal de cálcio ou em hipoestrogenismo precoce. Essas patologias incluem, entre outras, tireoideopatias, hipogonadismo, Síndrome de Cushing, diabetes, hiperparatireoidismo, câncer metastásico, mieloma múltiplo, doenças inflamatórias crônicas 
intestinais, gastrectomia, doenças renais crônicas e doença difusa do tecido conjuntivo (WEINSTEIN; BUCKWALTER, 2000). Além disso, a ingestão de fármacos como heparina, corticosteróides, retinóides, o sedentarismo e a baixa ingestão de cálcio podem predispor o aparecimento da doença (NOTELOVITZ, 2001).

A perda de massa óssea resulta da perda de cálcio e de outros minerais da matriz, que normalmente se inicia após os 30 anos na mulher e é acelerada por volta dos 45 anos, com a diminuição de níveis de estrógeno. Quando a mulher começa a ter perda óssea, aproximadamente $8 \%$ dessa massa se perde a cada 10 anos. A fragilidade resulta da diminuição da síntese protéica, reduzindo, portanto, fibras colágenas que dão ao osso a condição de tensionado, resultando em um osso quebradiço e sujeito a fratura. A perda da massa óssea também pode causar deformidades, dor, rigidez, perda de altura e perda dos dentes (TORTORA; GRABOWSKI, 2002).

Segundo Gasperino (2002 apud BAGNOLI, 2001)² a redução progressiva do conteúdo mineral ósseo caracteriza osteopenia e, em fases mais avançadas, a osteoporose. $\mathrm{Na}$ osteopenia, as atividades normais não causam fraturas espontâneas ou dores ósseas, só ocorrendo após quedas e ou impactos maiores (FROST, 1997). Já na osteoporose, tais evidências clínicas do excesso de fragilidade óssea estão associadas à redução acentuada do conteúdo mineral no tecido ósseo (FROST; JEE, 1992).

Segundo Rena (2003), o que diferencia osteoporose de osteopenia é a quantidade de cálcio que a mulher perde dos seus ossos, ou seja, é considerada normal a perda de até 10\% do cálcio dos ossos quando comparada com a mulher de 30 anos. O valor entre $10 \%$ e $25 \%$ classifica osteopenia e, acima disso, osteoporose.

\footnotetext{
${ }^{2}$ GASPERINO, J. (1995) Androgenic regulation of bone mass in women. Clinical Orthoaedics. p.311-278.apud In: BAGNOLI, V. R. et al. (1998). Síndrome do climatério, osteoporose: como diagnosticar e tratar. Revista Brasileira de Medicina, São Paulo, v.55, n.12, Dez. Disponível em: $<$ http: // www.cibersaude.com.br./ revistas.asp?fase $=$ r003\&id-materia $=1529>$. Acesso em 24 jun.2002.
} 
Embora a osteoporose possa ser definida como uma condição clínica, na qual existe uma perda óssea significativa, com uma redução da massa óssea além da considerada normal para pacientes da mesma idade e sexo (NORDIN,1987), essa pequena redução da massa óssea no osso osteoporótico não é uma explicação satisfatória para as grandes mudanças aparentes na fragilidade óssea (HEANEY, 1987), pois nem todos os indivíduos com densidade mineral óssea diminuída chegam a apresentar uma fratura.

Dessa forma, acredita-se que há outros aspectos estruturais e de qualidade do osso que levam ao aumento de fraturas. Estudos mostraram que há uma diferença no colágeno nativo na osteoporose. Dessa forma, a diminuição na densidade óssea em osteoporose está claramente relacionada à perda total de osso, mas a diferença entre baixa densidade óssea e suscetibilidade a fraturas está relacionada à modificação da estrutura do colágeno (BAILEY; KNOTT, 1999).

Outros estudos propõem que danos microscópicos no osso podem contribuir de forma significativa para o aumento da fragilidade óssea; micro-danos acumulativos causados por atividades diárias normais podem afetar a propriedade mecânica do osso (JOHNSTON; SLEMENDA, 1985).

Assim, muitos fatores podem interferir ou predispor à osteoporose e alguns parâmetros estruturais conferem fragilidade óssea (GILSANZ, 1998), entre eles: 1-variação entre mulheres: relaciona-se à área de secção transversal do osso, ou seja, a densidade óssea declina com a idade e a tensão em um osso com secção transversal pequena sofre uma desvantagem mecânica, ficando mais susceptível à fratura; 2-gêneros diferentes: a incidência de fraturas é maior em mulheres do que em homens, mas é resultante da diferença da secção transversa; 3diferenças raciais: a densidade óssea é maior em negros do que em brancos devido à grande espessura trabecular dos negros. Além disso, fatores genéticos contribuem para seu 
aparecimento, causando suscetibilidade ou resistência à fratura em osteoporose entre os idosos (Figura 3).

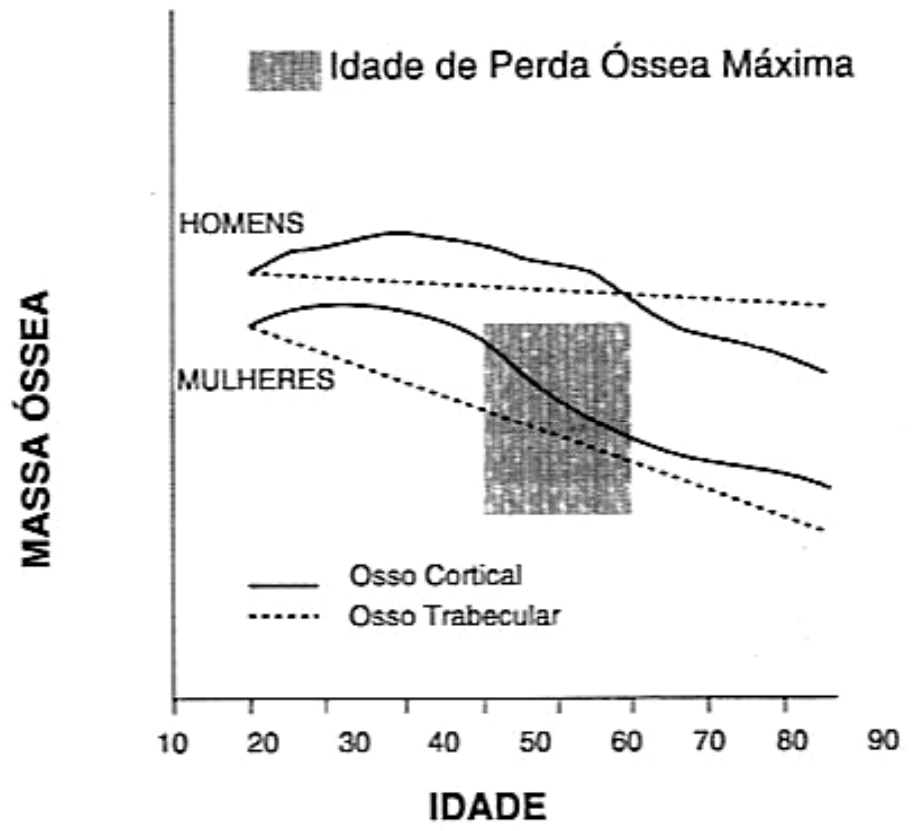

Figura 3. Gráfico relacionando perda óssea, idade e sexo no osso trabecular e cortical Fonte: NOTELOVITZ, M. (2000).

Embora a osteoporose seja uma patologia ainda não totalmente conhecida, vários fatores etiológicos acontecem juntos (Figura 4) na sua patogênese. Entre eles estão: subnutrição (proteína disponível de modo insuficiente a ponto de impedir a formação de matriz protéica), desuso ou imobilização (falta de pressão ou tensão sobre o osso diminui a produção óssea), falta de vitamina D (necessária para a secreção de substâncias intercelulares por todas as células, incluindo a formação de osteóide pelos osteoblastos), senilidade (com o avanço da idade, devido à redução do hormônio de crescimento e de outros fatores de crescimento, não ocorre deposição satisfatória de matriz), entre outros (NOTELOVITZ, 2001). 


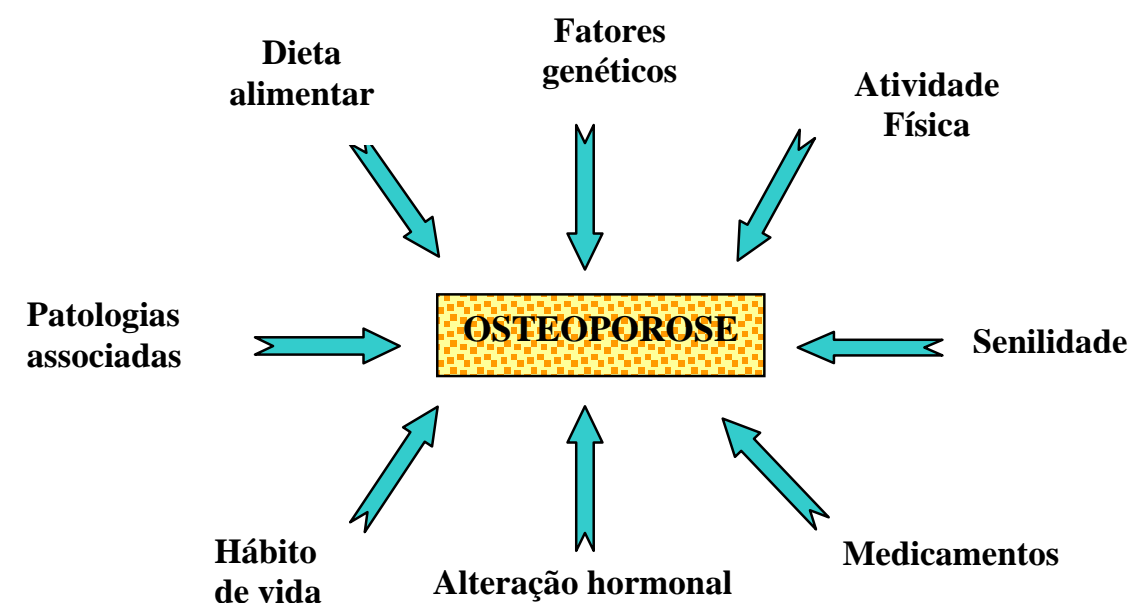

Figura 4. Esquema de fatores do determinismo para osteoporose

A deficiência hormonal é um dos principais fatores etiológicos (WEINSTEIN; BUCKWALTER, 2000), pois a falta de secreção de vários hormônios, além de exercer atividade estimulante sobre os osteoblastos, também regula a secreção renal e a absorção dietética de cálcio e fósforo, a reabsorção e a deposição mineral óssea, controlando a homeostase mineral e a concentração de cálcio sérico (KAPLAN et al., 1996).

Entre esses hormônios podemos citar:

* Hormônio da paratireóide (PTH): é um hormônio sintetizado pela glândula paratireóide e os alvos são o fígado e o tecido ósseo (KAPLAN et al., 1996). O PTH tende a aumentar a calcemia por diferentes mecanismos: aumento da absorção óssea, diminuição da excreção renal de cálcio e estímulo da síntese renal de vitamina D (calcitriol), o que secundariamente favorece a absorção intestinal de cálcio (RIANCHO; GUTIÉRREZ, 2003). O aumento da reabsorção se deve a um estímulo da atividade osteoclástica, pois se acredita que ele favorece a fusão dos precursores osteoclásticos e a atividade dos osteoclastos maduros, mas também exerce efeito sobre os osteoblastos e, em doses adequadas, aumenta a massa óssea. 
*Vitamina D: A vitamina D, procedente da dieta e, sobretudo, da síntese endógena da pele, é hidroxilada no fígado e depois no rim. Age sobretudo no intestino, levando à absorção de cálcio, o que estimula a calcemia; no osso, ela age aumentando o recrutamento de osteoclastos, estimulando a síntese de proteínas pelos osteoblastos e participando na mineralização da matriz. A deficiência de vitamina D causa mineralização deficiente, enquanto que o excesso de vitamina D leva à perda óssea (KAPLAN et al., 1996). Sua ação sobre os osteoclastos é indireta, uma vez que são mediados pelos osteoblastos, mas esse efeito é pouco perceptível, pois o aumento da absorção de cálcio freia a secreção do PTH; conseqüentemente, diminui a reabsorção óssea. Porém, ele exerce ação direta sobre a estirpe osteoblástica, traduzindo-se em incrementos da síntese de proteínas como a osteocalcina e a fosfatase alcalina (RIANCHO; GUTIÉRREZ , 2003).

* Calcitonina: é produzida pelas células C da glândula tireóide e sua principal função fisiológica é inibir os osteoclastos (WEINSTEIN; BUCKWALTER, 2000). Trata-se de um efeito direto mediado pela interação com receptores presentes no osteoclastos (RIANCHO; GUTIÉRREZ, 2003).

* Hormônios da tireóide $\left(\mathrm{T}_{4}\right.$ e $\left.\mathrm{T}_{3}\right)$ : têm efeitos diretos e indiretos sobre o osso, de forma que sofre ação dos fatores de crescimento locais e age sobre as células ósseas (WEINSTEIN; BUCKWALTER, 2000). Esses hormônios aumentam a freqüência de ativação das unidades de remodelamento e, portanto, aceleram a velocidade de trocas. $\mathrm{O}$ hipertireoidismo aumenta as taxas de reabsorção e de produção óssea com predomínio da reabsorção, resultando em perda mineral óssea e redução de massa óssea (RIANCHO; GUTIÉRREZ, 2003).

*Glicocorticóide: este hormônio tem receptores em células ósseas e sua atividade excessiva resulta em inibição dos osteoblastos com inibição da formação de matriz, diminuição da síntese de colágeno e osteocalcina, diminuição da absorção de cálcio com 
hiperparatireoidismo secundário (KAPLAN et al., 1996). Além de inibir a expressão de integrinas, dificultando sua adesão à matriz e, presumivelmente, o depósito de osteóide, considera-se sua ação indireta sobre o tecido ósseo, colaborando a favor da reabsorção, pois aumenta a secreção de PTH ou a expressão dos seus receptores sobre o tecido ósseo (RIANCHO; GUTIÉRREZ, 2003). O uso prolongado de corticosteróides leva ao decréscimo da massa óssea (WEINSTEIN; BUCKWALTER, 2000).

* Hormônio de crescimento: este hormônio apresenta-se importante não só no período de crescimento, mas também na idade adulta, pois estimula a proliferação e diferenciação do osteoblasto; também estimula a osteoclastogênese (RIANCHO; GUTIÉRREZ, 2003).

* Hormônios sexuais: O estrógeno tem efeito sobre o osteoblasto e osteoclasto; contudo, seu efeito sobre o tecido ósseo se traduz na diminuição da reabsorção (RIANCHO; GUTIÉRREZ, 2003). No osteoclasto, há inibição da reabsorção direta e indiretamente, por um efeito modulador dos osteoblastos sobre os osteoclastos, mediado por uma troca de vitamina D e PTH (RIANCHO; GUTIÉRREZ, 2003). No osteoblasto, ação desses hormônios leva ao aumento do seu número e da síntese de colágeno, aumentando o RNAm osteoblástico para TGF- $\beta$, o que resulta no aumento dos receptores de progesterona osteoblásticos (WEINSTEIN; BUCKWALTER, 2000). Teoricamente, esse hormônio favorece a formação óssea, posto que estimula a síntese de fatores de crescimento como o IGF e o TGF- $\beta$ (RIANCHO; GUTIÉRREZ , 2003).

Outros hormônios sexuais como a progesterona estimulam a neoformação óssea e bloqueiam a atividade do glicocorticóide no osso; já o andrógeno reduz o turnover ósseo e leva ao aumento da atividade osteoclástica (WEINSTEIN; BUCKWALTER, 2000). 


\subsection{Tecido ósseo}

\subsubsection{Forma e função}

O osso é um tecido conectivo que, juntamente com a cartilagem, forma o sistema esquelético. Esse tecido tem três funções, quais sejam: mecânica, proteção e metabólica. Segundo Weinstein e Buckwalter (2000), sua função é mecânica ao servir de local para inserção dos músculos, permitindo a locomoção e a movimentação dos segmentos do corpo. A função de proteção é vital ao envolver órgãos nobres e medula espinhal, ao passo que a função metabólica ocorre com a reserva de íons para todo o organismo, especialmente o cálcio e o fósforo, cuja homeostase é fundamental ao organismo.

O osso é um tecido conectivo vital e dinâmico, refletindo o equilíbrio entre prover a integridade mecânica para a locomoção, proteção e envolvimento no caminho metabólico associado à homeostase mineral. Associado a isso, o osso é o local primário da hematopoese. Estudo recente mostra sua importância como componente do sistema imune (NOTELOVITZ, 2001).

Anatomicamente (Figura 5), o tecido ósseo é organizado em osso trabecular ou esponjoso e cortical ou compacto (WEINSTEIN; BUCKWALTER, 2000). 


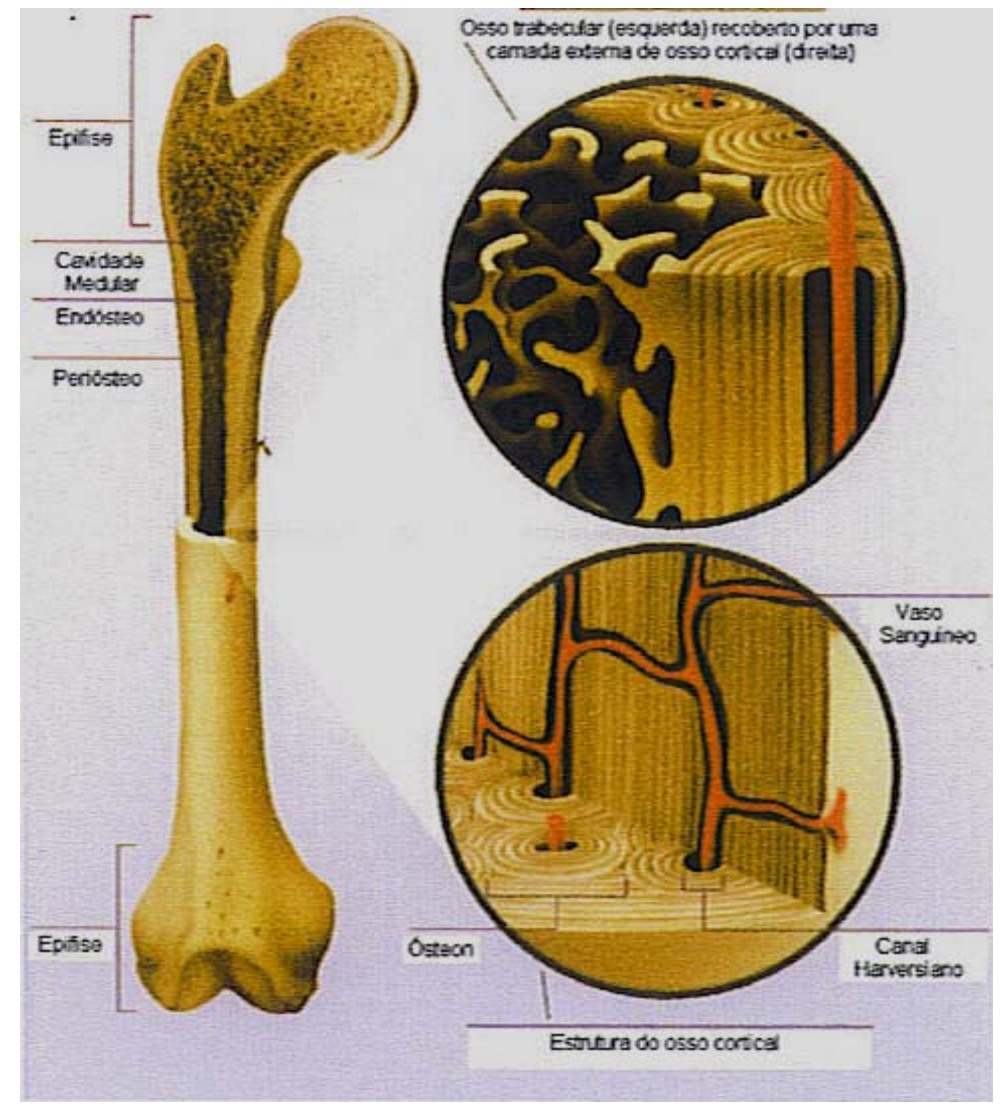

Figura 5. Esquema representativo do fêmur humano - osso cortical e trabecular Fonte: http//: www.medes.fr/Eristo/osteoporosis/ BonePhysiologyImage.htm.

O osso cortical tem quatro vezes a massa do osso trabecular, embora a porcentagem de remodelamento do osso trabecular seja muito maior que do osso cortical (KAPLAN et al., 1996; WEINSTEIN; BUCKWALTER, 2000). Segundo Neto e Fernandes (2001), espera-se que o osso trabecular seja remodelado em $25 \%$ do seu total anualmente, em comparação com apenas $2 \%$ a $3 \%$ do osso cortical. Essa característica explica a maior incidência de fraturas em locais de predominância de osso trabecular, que apresenta maior atividade metabólica devido a maior vascularização.

A arquitetura do osso parece ser determinada principalmente pela orientação de tensão, resultando de simultâneas configurações de cargas (MARCUS; FELDMAN; KERSEY, 1996). De uma forma simplista, o osso respeita a lei de Wolff, a qual sugere que "forma segue função"; assim, quando se aplicam tensões sobre um osso, as trabéculas desse 
osso se desenvolvem e se alinham para adaptar-se a essas linhas de tensão (KAPLAN et al., 1996).

\subsubsection{Composição do tecido ósseo}

A composição do tecido ósseo abrange uma fase mineral e uma orgânica. Aproximadamente $70 \%$ da fase mineral ou matéria inorgânica, 5 a $8 \%$ de água, e o restante, a fase orgânica ou matriz extracelular [MEC, doravante]. Dessa fase mineral, cerca de 95\% é composta de hidroxiapatita [HA, doravante] e outros componentes minerais completam o 5\% restante, ao passo que, na fase orgânica, 98\% dela é composta de colágeno Tipo I e uma variedade de proteínas não-colagênicas que, junto com as células ósseas, completam o restante $\%$ dessa fase (WEINSTEIN; BUCKWALTER; 2000).

Os componentes inorgânicos e orgânicos do tecido ósseo apresentam propriedades estruturais e regulatórias, pois tanto células ósseas, que são as principais reguladoras do metabolismo ósseo, quanto a matriz óssea e mineral participam no controle de processos mediadores celulares (MARCUS; FELDMAN e KELSEY, 1996). Fatores de crescimento e citocinas, proteínas indutivas do osso como a osteonectina, osteopontina, sialoproteina óssea, osteocalcina, proteoglicanas ósseas e outras fosfoproteínas e proteolipídeos têm uma pequena contribuição no volume total ósseo e maior contribuição em sua função biológica (KAPLAN et al., 1996).

Segundo Chiquet (1999), a MEC é o substrato para adesão celular, crescimento e diferenciação, promovendo informação para o desenvolvimento celular e tecidual que ocorre, por um lado, através de células ligadas à "motifs" em suas proteínas próprias, como, por exemplo, a seqüência peptídica do RGD em fibronectina, e, por outro lado, através de fatores de crescimento presentes e morfogênese para as células. 
Essa MEC é altamente especializada em estrutura e composição para suportar diferentes tipos de stress mecânico, como tensão e cisalhamento. Sua função mecânica é de grande importância, pois, sem a MEC, o organismo não teria suporte e não poderia manter a sua forma (HAY, 1992). Acredita-se que o tipo e a magnitude desse stress mecânico, aplicado ao tecido ósseo, controlam a proporção e a composição da MEC (CHIQUET, 1999).

$\mathrm{Na}$ vida embrionária, o processo de ossificação se inicia com as células mesenquimatosas, diferenciando-se em condrócitos, os quais proliferam e secretam uma substância intercelular. Esses condrócitos amadurecem e secretam fosfatase alcalina e a matriz cartilaginosa se calcifica, dificultando a difusão de nutrientes; assim, os condrócitos morrem e a matriz calcificada sofre desintegração e dissolução. Há proliferação de tecido altamente vascular e celular e osteoblastos envolvem os remanescentes da cartilagem calcificada e depositam osso (WEINSTEIN; BUCKWALTER, 2000). Até o crescimento ósseo completo, essa seqüência de acontecimentos é contínua.

Segundo Francis, Sutcliffe e Scane (1998), as atividades celulares do tecido ósseo são de 3 tipos:

- Atividade de modelagem: associada ao crescimento, transformando o osso do recémnascido em osso adulto;

- Atividade de reparo: relacionada à reparação contínua de micro e macroestrutura do esqueleto quando danificadas por fadiga ou trauma devido a tensões físicas recebidas;

- Atividade de remodelagem: relacionada à manutenção da homeostasia da atividade mineral do sangue por meio da absorção de material e neoformação óssea.

\subsubsection{Células ósseas}


Entre as células que compõem o tecido ósseo e são responsáveis pela manutenção do mesmo, podemos citar: osteoblasto, osteoclasto e osteócito (Figura 6).

\section{* Osteoblasto}

Os osteoblastos são células de revestimento responsáveis por sintetizar os constituintes da matriz, como o colágeno Tipo I, suporte para a mineralização orientada de HA e a camada básica de proteoglicanos e glicoproteínas (MARCUS; FELDMAN; KERSEY, 1996). Outras funções incluem a regulação da remodelagem óssea e o metabolismo mineral (WEINSTEIN; BUCKWALTER, 2000).

Osteoblastos são de origem mesenquimal, precursores de fibroblastos (RODAN; RODAN, 1983). Em geral, encontram-se revestindo uma camada de matriz óssea ainda não calcificada (tecido osteóide) e, quando a formação óssea termina em um local particular, o osteoblasto horizontaliza-se e torna-se célula óssea de revestimento, que cobre toda superfície óssea do endósteo e se torna osteócito, uma vez que ele se incrusta dentro de sua matriz (NOTELOVITZ, 2001).

Segundo Steln, Lian e Owent (1990), os osteoblastos, além de produzirem matriz osteóide, base para o início da mineralização óssea, também têm ligação com moléculas que comandam várias funções celulares, como por exemplo, a membrana plasmática do osteoblasto, que é caracteristicamente rica em fosfatase alcalina, enzima importante na mineralização da MEC, pois catalisa a hidrólise de ésteres de fosfato com Hidroxilisina [Hyl, doravante] em um $\mathrm{pH}$ alcalino e também apresenta receptores para o $\mathrm{PTH}$, estrógeno e vitamina $\mathrm{D}$ em seu núcleo.

Outras proteínas não-colagênicas são produzidas pelo osteoblasto, como: osteonectina, osteopontina, Sialoproteina óssea, Gla-glicoproteina, glicoproteina ácida e a osteocalcina (POLLACK, 1984). 


\section{* Osteoclasto:}

Os osteoclastos são células de revestimento cuja função principal é a desmineralização óssea com conseqüente solubilização da matriz do osso (NOTELOVITZ, 2001). Eles pertencem à linhagem de macrófago-monócito da medula óssea e estão disponíveis na circulação até se tornarem funcionalmente ativos, enfileirando-se na superfície formadora do tecido ósseo (KAPLAN et al., 1996). Através da sua borda ondulada, cria uma estreita ligação com a superfície mineralizada, formando uma área de $\mathrm{pH}$ baixo, necessária para a dissolução do mineral iniciando a absorção de osso (LERNER, 2000).

$\mathrm{Na}$ remodelagem, são solicitados osteoclastos no local de reabsorção, que é subseqüentemente preenchido pelos osteoblastos, os quais expressam receptores para agentes que são estimulantes da absorção como o PTH e vitamina D, entre outros (RODAN; RODAN, 1983). Dessa forma, a reabsorção é geralmente ligada à formação óssea.

\section{*Osteócitos:}

Segundo Pollack (1984), o osteoblasto, após 10 dias, assume uma estrutura tridimensional, formando o osteóide que, após a sua mineralização, é aprisionado na matriz. Esse osteoblasto incrustado na matriz recebe o nome de osteócito, sendo considerado uma célula óssea senil (KAPLAN et al., 1996), ou seja, um osteoblasto maduro que, embora incapaz de sintetizar colágeno ou matriz osteóide por muito tempo, tem a importante função de proteger a superfície óssea da reabsorção (RODAN; RODAN, 1983; NOTELOVITZ, 2001). 


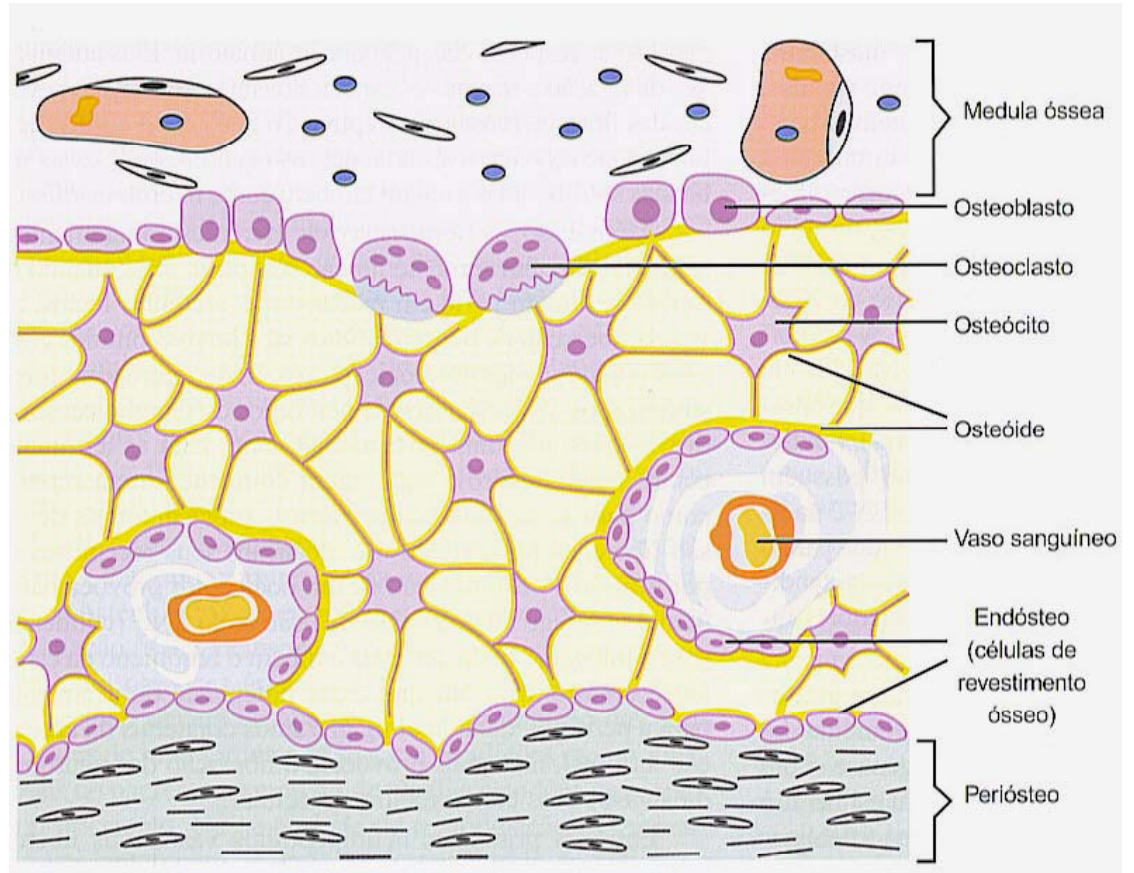

Figura 6. Esquema representativo da localização das células ósseas.

Fonte: http//: www.medes.fr/Eristo/osteoporosis/ BonePhysiologyImage.htm

Alguns autores como Steln, Lian e Owent (1990), Marcus, Feldman e Kersey (1996) acreditam que osteócitos sejam os mecanossensores que detectam os sinais mecânicos, induzindo a matriz a começar a se formar ou se desintegrar de acordo com a carga mecânica transmitida para as células efetoras - osteoblastos e osteoclastos.

\subsubsection{Colágeno}

O colágeno é uma proteína estrutural muito importante nos vertebrados e corresponde a aproximadamente $25 \%$ de toda proteína no corpo humano, por conseguinte, a $6 \%$ do peso corporal (ALBERTS et al., 1994). Está presente na maioria dos tecidos (ossos, cartilagens, pele, veias, órgãos, entre outros), conferindo funcional integridade e estrutura a esses. Como resultante do processo biossintético, são formados 19 tipos diferentes de cadeias alfa que, por 
associação na forma de trímeros, dão origem a pelo menos 27 tipos de colágenos (MYLLYHARJU; KIVIRIKKO, 2004); entre esses, o colágeno Tipo I é o mais abundante no corpo humano (ALBERTS et al., 1994). Do total da matéria orgânica, mais de $90 \%$ é formado por colágeno do Tipo I e 3\% do Tipo V, cuja função não é conhecida (GOLDBERG; SMITH, 2004).

\subsection{Estrutura do colágeno Tipo I}

O colágeno Tipo I é formado por 3 cadeias $\alpha$, sendo 2 cadeias $\alpha^{1}$ e 1 cadeia $\alpha^{2}$, que se enrolam entre si para formar uma estrutura chamada tripla hélice (CHAPMAN; TZAPHLIDOU; MEEK, 1990). Nas duas extremidades dessa região helicoidal há uma região não helicoidal, designadas telopeptídeo C-terminal e N-terminal. Cada cadeia $\alpha$ (Figura 7) é formada por uma seqüência de aminoácidos que apresentam uma glicina [Gly, doravante] a cada terceiro resíduo da cadeia, caracterizando no colágeno uma estrutura de triplete repetitivo na forma: Gly - X - Y, onde X e Y podem ser Prolina [Pro, doravante], Hidroxiprolina [Hyp, doravante] ou outro aminoácido, os quais podem ter naturezas ácidas, básicas e hidrofóbicas (BAILEY, 2001).

As cadeias $\alpha^{1}$ e $\alpha^{2}$ apresentam 1056 e 1035 resíduos de aminoácidos, respectivamente, ao passo que o telopeptídeo C-terminal apresenta 26 resíduos de aminoácidos e o N-terminal, 16 resíduos de aminoácidos (CHAPMAN; TZAPHLIDOU; MEEK, 1990). 


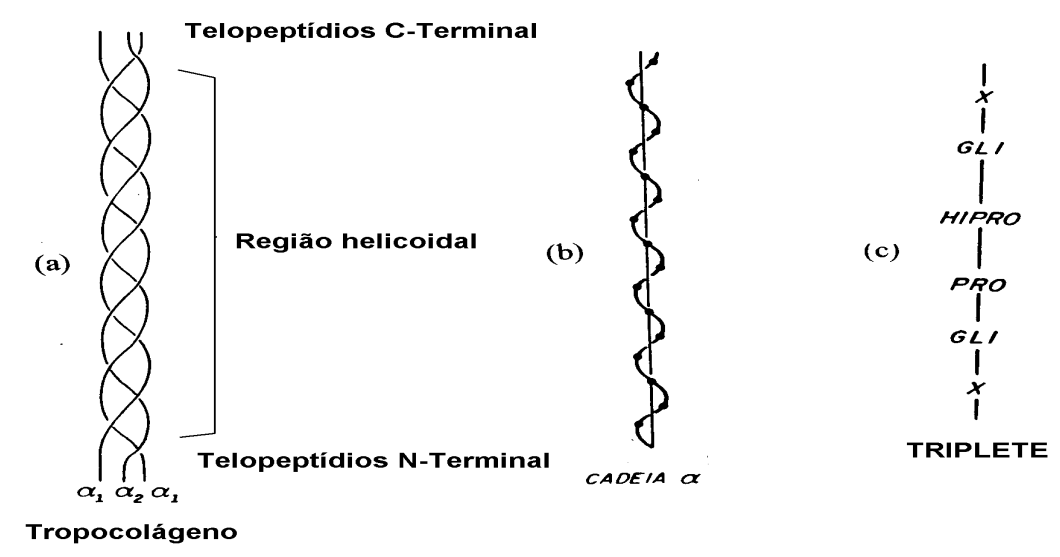

Figura 7. Microestrutura do colágeno Tipo I Fonte: SILVA, S. (2005)

É sintetizado na forma de pró-colágeno e, quando no meio extracelular, perde parte de sua estrutura protéica, dando origem a estruturas fibrilares (CHAPMAN; TZAPHLIDOU; MEEK, 1990). Essas fibrilas, após impregnação com sais de metais pesados seguidos da observação pela Microscopia Eletrônica de Transmissão [MET, doravante], são caracterizadas pela presença repetitiva de zonas claras e escuras que formam a unidade estrutural do colágeno (Figura 8), denominado de período D com 670 Å. Na coloração negativa da MET, as zonas claras, que são zonas de maior densidade de aminoácidos, são classificadas como Overlap e têm 310 A, ao passo que as zonas escuras, chamadas de Gap, têm menor densidade de aminoácidos e seu comprimento é de $360 \AA$ (TENÓRIO; SANTOS; ZORN, 2003). Com a coloração positiva da MET, observou-se que as bandas claras e escuras são caracterizadas também por uma subperiodicidade que, em função da técnica empregada, reflete a regularidade e a periodicidade da distribuição dos aminoácidos ácidos e básicos presentes na estrutura fibrilar. Dessa forma, a região do Overlap abrange os sub-períodos $\mathbf{c}_{\mathbf{1}}$, $\mathbf{b}_{2}, \mathbf{b}_{1}$ e $\mathbf{a}_{4}$, enquanto a região do Gap inclui os sub-períodos; $\mathbf{a}_{3}, \mathbf{a}_{2}, \mathbf{a}_{1}, \mathbf{e}_{2}, \mathbf{e}_{1}, \mathbf{d}, \mathbf{c}_{3}$ e $\mathbf{c}_{2}$. (CHAPMAN; TZAPHLIDOU; MEEK, 1990), levando-nos a compreender a formação de “clusters” (Fig 8b) de aminoácidos ácidos e básicos ao longo do período D. 

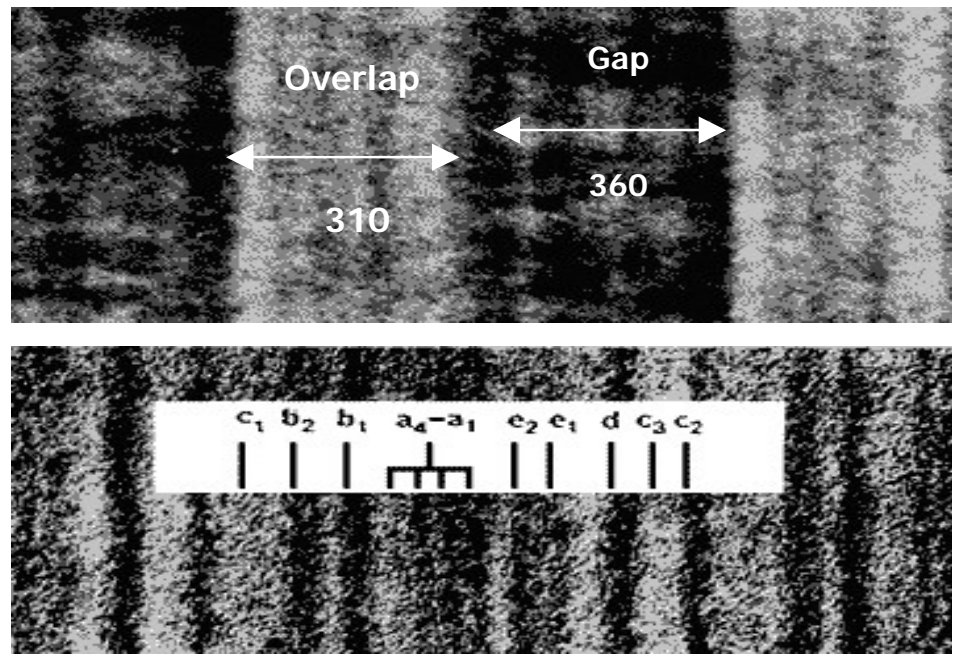

Figura 8. Micrografia de Microscopia Eletrônica de Transmissão de fibras de colágeno do Tipo I obtida após impregnação de acetato de uranila e fosfotungstato de amônio: (a) Impregnação negativa e (b) Impregnação positiva

Assim, o modelo fibrilar quarto alternado (CHAPMAN; TZAPHLIDOU; MEEK, 1990), definido por Smith em 1963, define o tropocolágeno, unidade estrutural da molécula de colágeno que se organiza em número de 5 , de forma escalonada e alternada de $1 / 4$ de seu comprimento (Figura 9b), formando a microfibrila (KAPLAN et al., 1996; WEINSTEIN; BUCKWALTER, 2000). Esse modelo, quando comparado com a MET (Figura 9a), mostra que essas moléculas de tropocolágeno não estão distribuídas aleatoriamente na estrutura fibrilar e a sua agregação espontânea na fibrila é produzida pela interação de grupos ácidos e básicos presentes na mesma molécula ou em moléculas adjacentes (WEINSTEIN; BUCKWALTER, 2000). 


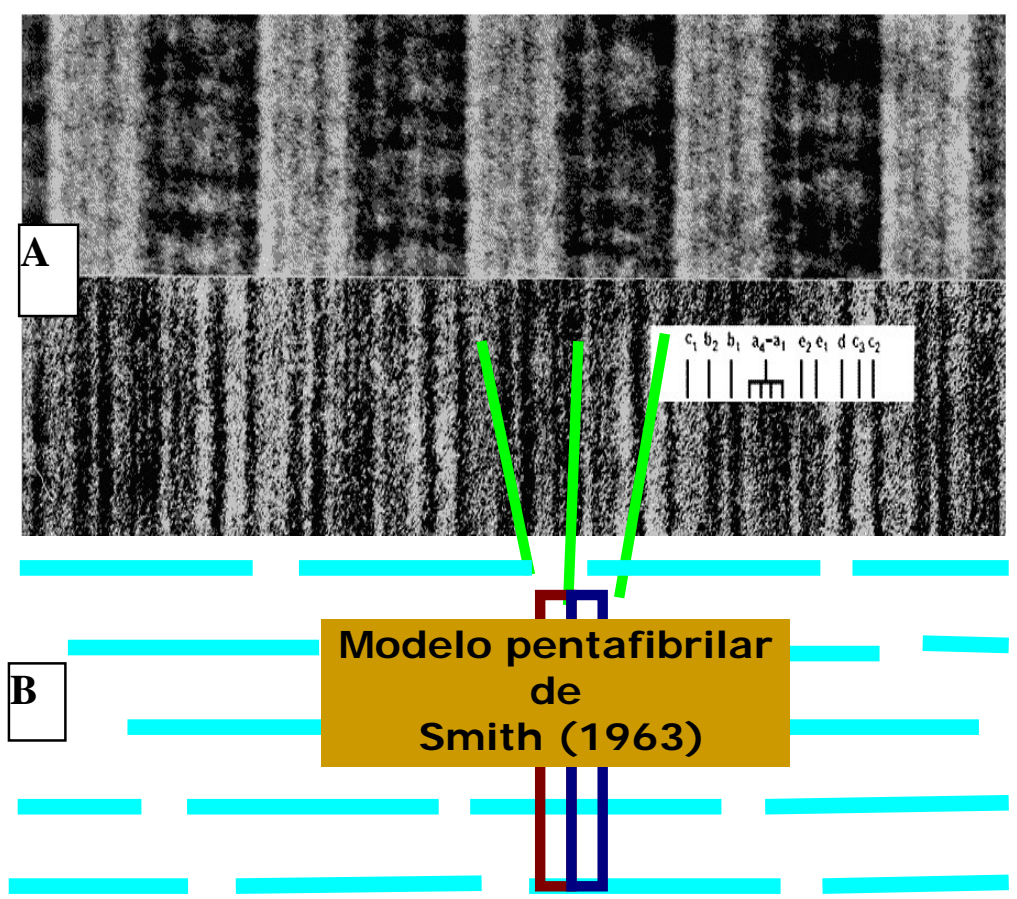

Figura 9. Comparação de Microscopia Eletrônica de Transmissão com Modelo Pentafibrilar de Smith: (a) Formação de periodicidade e subperiodicidade do colágeno Tipo I; (b) figura representando Modelo Pentafibrilar de Smith

Essas microfibrilas de colágeno agregar-se-ão lateral e longitudinalmente por um processo chamado fibrilogênese (WEINSTEIN; BUCKWALTER, 2000) e formarão as fibrilas de colágeno (Figura10), as quais são mantidas por ligações cruzadas intermoleculares (ou interfibrilares) e intramoleculares (ou intrafibrilares) e também por interações eletrostáticas que lhes conferem a estabilidade (BAYLE et al., 1998).

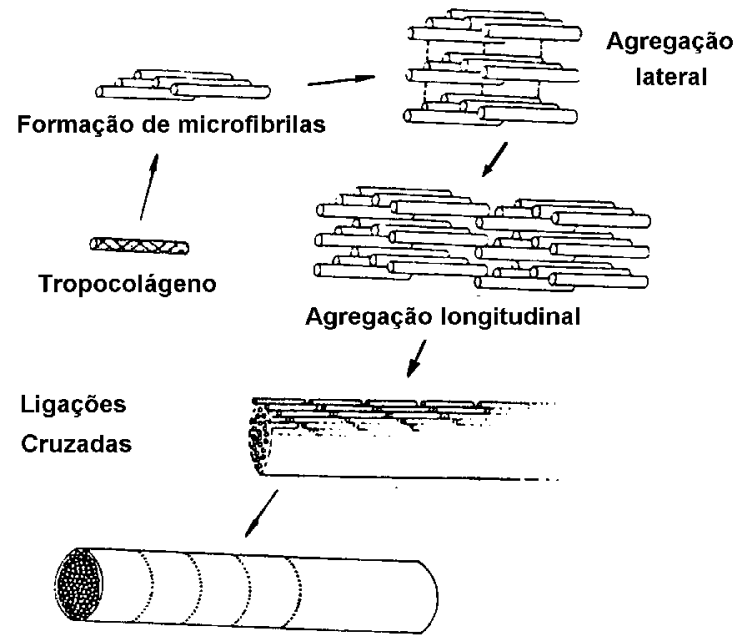

Fibrila de Colágeno

Figura 10. Processo de fibrilogênese do colágeno Fonte: SILVA, S. (2005) 


\subsection{Função do colágeno Tipo I}

Embora o colágeno seja uma proteína estruturalmente simples, tem funções bastante variadas, desde mecânica até como "reguladora" da atividade celular. Nos tecidos moles, atribui-se ao colágeno a importante função mecânica de manter a forma dentro dos limites que permitem o funcionamento normal do organismo ou tecido sob a ação de qualquer força que a tente modificá-la (KAPLAN et al., 1996). Ele fornece resistência e integridade estrutural a diversos tecidos e órgãos, sendo encontrado nas vísceras e na intimidade delas, na derme, nos tendões, na cartilagem, na córnea, no humor vítreo, nos vasos sanguíneos, na membrana basal, nos ligamentos, entre outros (NOTELOVITZ, 2001). Tendões e ligamentos são estruturas ricas em colágeno e possuem funções de força que são muito necessárias; os tendões transmitem força dos músculos para os ossos, enquanto os ligamentos conectam ossos, reposicionando-os na estabilização das articulações (WEINSTEIN; BUCKWALTER, 2000).

No tecido ósseo, o colágeno também apresenta importante função mecânica, pois o esqueleto é formado por tecido ósseo e esse, por sua vez, é formado por colágeno do Tipo I. O tecido ósseo apresenta funções que são: sustentação para o sistema musculoesquelético, proteção de órgãos internos vitais e reservatório metabólico, trabalhando para hematopoese, homeostase de cálcio, entre outras (GUYTON, 1991; JUNQUEIRA; CARNEIRO, 1990). Até recentemente, sua principal função era manter a estrutura física de uma espécie devido às suas propriedades mecânicas resultantes de sua organização fibrilar (VIIDIK; VUUST, 1990). Atualmente, sabe-se que o colágeno Tipo I no tecido ósseo apresenta uma nobre função, pois somente após ser formando a região do Gap, é que ocorre a deposição da HA. Dessa forma, o colágeno permitir a mineralização do tecido ósseo. 


\subsubsection{Proteínas não-colagênicas}

As proteínas da MEC do tecido ósseo e da dentina, que se encontram nos dentes, podem ser divididas em 2 categorias: as colagênicas e as não-colagênicas. Em ambos os tecidos, a fase orgânica em sua maior parte é composta por proteínas colagênicas, principalmente por colágeno Tipo I, e não-colagênicas (GOLDBERG; SMITH, 2004). Essas últimas, na sua maioria, são proteínas ácidas e influenciam a mineralização e remodelagem do tecido ósseo. Elas são compostas por proteoglicanas (decorina e biglicana), osteopontina, Sialoproteina bovina [BSP, doravante], osteonectina, proteínas morfogênicas ósseas [BMPs, doravante] e osteocalcina.

Algumas dessas proteínas não-colagênicas são exclusivas da dentina e, entre elas, podemos citar (BENISH et al., 2000; HE et al., 2003): fosfoproteína siálica dentinária [DSPP, doravante], fosfoproteína dentinária [DPP, doravante], sialoproteina dentinária [DSP, doravante] e a matriz protéica dentinária $\left[\mathrm{DMP}_{1}\right.$ e $\mathrm{DMP}_{2}$, doravante].

Resumidamente podemos descrever:

* Decorinas e Biglicanas: Segundo Tenório, Santos e Zorn (2003), ambas as proteínas pertencem ao grupo das proteoglicanas e estão presentes em diferentes órgãos e tecidos. No tecido ósseo, elas participam do controle dos processos inflamatórios e remodelagem, além de participarem do processo de mineralização.

No processo de mineralização, as Biglicanas aparentemente facilitam a nucleação dos cristais de HA, enquanto as Decorinas, embora presentes em todas as fases desse processo, interferem de modo mais acentuado na etapa que antecede a nucleação primária na zona do Gap (BERTHET-COLOMINAS; MILLER; WHITE, 1979), pois, somente após sua remoção da superfície do colágeno, as fibrilas se fundem e se reorganizam (HOSHI et al., 1999), 
criando o espaço necessário para a mineralização, provavelmente alterando não apenas a estrutura na zona do Gap, mas também a distribuição de cargas ao longo da microfibrila (MAITLAND; ARSENAULT, 1991).

Há evidências de que a função da Decorina é manter íntegra a estrutura do colágeno, ao mesmo tempo em que esconde os sítios potenciais que dão origem à nucleação primária (HOSHI et al., 1999). A sua interação com o colágeno ocorre na região C-terminal, coincidindo com a banda $\mathbf{c}_{1}$ do período D do colágeno (DOUGLAS et al., 2000), sítio esse no colágeno que corresponde aos locais de deformações estruturais induzidas por ações mecânicas (BARENBERG; FILISKO; GEIL, 1978).

* Osteopontina: Esta glicoproteína encontrada na MEC de todos os tecidos e no tecido ósseo, depois do colágeno, é o componente protéico mais importante. É rica em resíduos de Asp e torna-se mais ácida pela fosforilação dos resíduos de Serina [Ser, doravante] e Treonina [Thr, doravante]. Tem vários domínios para adesão celular do tipo RGD, importante para osteoblastos e osteoclastos, estando empregada na regulação da mineralização. Sua concentração aumenta significantemente na presença de doenças tais como câncer, aterosclerose, estenose de biopróteses valvulares e infarto do miocárdio, sugerindo que essa proteína tem uma função importante no sistema de defesa do organismo (SREENATH et al., 2003).

* BSP: Diferentemente de outras proteínas que são distribuídas amplamente em vários tecidos, a BSP é distribuída apenas no tecido ósseo, tendo grande afinidade pelo colágeno Tipo I. Sua interação ocorre na vizinhança da interface Overlap:Gap do período D, da mesma forma que a Decorina. Sua disposição espacial e temporal coincide com as etapas 
iniciais do processo de mineralizaçao. Assim como a osteopontina, a BSP contém a seqüência RGD e, portanto, envolvida com a interação matriz:célula (SREENATH et al., 2003).

* Osteonectina: São produzidas pelos osteoblastos e media a deposição de HA; liga-se a fatores de crescimento e influencia o ciclo celular(NOTELOVITZ, 2001).

* Osteocalcina: É a proteína não-colagênica mais abundante no tecido ósseo, totalizando $10 \%$. Encontra-se distribuída restritamente nas células de tecidos calcificados, tendo uma forte interação com a HA (BERDAL et al., 1991). É importante para o recrutamento de células osteoprogenitoras em regiões de absorção óssea (MARCUS; FELDMAN; KELSEY, 1996). Diferentemente da osteopontina e da BSP, é produzida apenas nos estágios finais da mineralização e o seu mecanismo de ação sobre o tecido ósseo ainda não é conhecido (BERDAL et al., 1991).

* BMPs: Tem essa denominação por induzir a formação de tecido ósseo quando implantadas no subcutâneo ou no tecido muscular. Sua função exata ainda não é conhecida, mas sabe-se que tem um papel importante no desenvolvimento do tecido ósseo, principalmente na embriogênese (SYKARAS; OPPERMAN, 2003).

* DSPP: Até recentemente pensava-se que essa molécula pertencesse exclusivamente à dentina, mas sabe-se que ela é produzida também no tecido ósseo (BENIASH et al., 2000; HE et al., 2003). Essa proteína, por clivagem, dá origem à Fosfoproteína dentinária (DPP) e à Sialoproteina dentinária (DSP). 
* DPP: Ricas em seqüências contendo resíduos de Asp e Fosfoserina, essa proteína tem uma grande afinidade por cálcio, sugerindo sua participação na nucleação da HA para formação da dentina, estando localizada na frente de mineralização (BENIASH et al, 2000; HE et al., 2003).

* DSP: É uma glicoproteína com alto grau de fosfarilação e rica em seqüências contendo resíduos de Asp. Também se encontra localizada na frente de mineralização; contudo, evidências recentes sugerem que seu efeito sobre a deposição e crescimento da HA é limitado (BENIASH et al., 2000; HE et al., 2003).

* $\underline{\mathrm{DMP}}_{1}$ : É uma proteína ácida rica em Ser e Asp, produzida por odontoblastos maduros e envolvida ativamente na produção da matriz mineralizada da dentina (BENIASH et al., 2000; HE et al., 2003).

Além das funções regulatórias sobre a mineralização, DSPP, DPP e DSP e DMP ${ }_{1}$, apresentam também a seqüência RGD para adesão celular.

* $\underline{\mathrm{DMP}}_{2}:$ Também chamada de fosfoforina, é uma proteína exclusiva da dentina, apresentando um alto grau de fosforilação, sendo a mais abundante depois do colágeno. Fosfoforinas de várias fontes contêm entre 35\% a 45\% de resíduos de Asp, e $40 \%$ a 55\% de Ser, dos quais 90\% encontram-se fosforilados (BENIASH et al., 2000; HE et al., 2003). Tem um pI de 1,1 e só é encontrada na fase inicial de mineralização (DAHL; SABSAY; VEIS, 1998), controlando o crescimento dos cristais de HA (BENIASH et al., 2000). O seu sítio de interação com o colágeno foi definido com sendo próximo à interface Overlap:Gap, com o centro de sua ligação a aproximadamente $210 \AA$ da região N-terminal (DAHL; SABSAY; VEIS, 1998). 


\subsubsection{Dinâmica do tecido ósseo - Remodelagem}

O osso é um tecido vivo que está continuamente em ação (FRANCIS; SUTCLIFFE; SCANE, 1998). Ao contrário de sua aparente inércia, o osso está sendo constantemente formado pelo osteoblasto e reabsorvido pelo osteoclasto, o que é essencial por assegurar um tecido ósseo renovado e manter suas funções mecânicas. Sua manutenção depende de um suprimento adequado de seus componentes, tanto de origem orgânica como inorgânica, principalmente o cálcio e o fósforo (WEINSTEIN; BUCKWALTER, 2000).

O osso é uma fonte constante de cálcio metabólico, mostrando que apresenta natureza dinâmica e está sujeito à alteração morfológica induzida pela variação de pressões exercidas sobre ele, além de outros fatores (CHIQUET, 1999). Esse mecanismo, que altera a geometria do tecido ósseo em função das demandas mecânicas externas exercidas sobre ele, recebe o nome de Remodelagem (WEINSTEIN; BUCKWALTER, 2000).

Resumidamente, a remodelagem pode ser descrita em 4 etapas (Figura 11):

\section{*Ativação}

Os osteoclastos maduros são ativados somente depois de se danificar a camada de osteóide que cobre a superfície do osso. Essa exposição da matriz mineralizadora subjacente deve ser causada pela degradação da superfície osteóide pela colagenase (WEINSTEIN; BUCKWALTER, 2000).

*Reabsorção

Os osteoclastos recém-formados secretam uma substância ácida, proveniente de sua borda ondulada. Essas substâncias são enzimas proteolíticas que solubilizam a matriz orgânica e são liberadas dos lisossomos dos osteoclastos, além de vários ácidos que ocasionam a dissolução da HA e são liberados principalmente das mitocôndrias. Em geral, os 
osteoclastos existem em massas pequenas, porém concentradas, que corroem o osso formando uma cavidade (NOTELOVITZ, 2001).

*Inversão

O processo de reabsorção cessa quando a cavidade formada alcança determinada profundidade. Nessa fase, células derivadas de monócitos formam uma superfície de cemento, que previne a erosão óssea adicional (NOTELOVITZ, 2001).

\section{*Osteogênese}

Os osteoblastos são atraídos para dentro da cavidade resultante da reabsorção e amadurecem sob a influência de vários hormônios e fatores de crescimento, para preencher a cavidade com osso neo-formado, o qual será depositado em camadas sucessivas na forma de círculos concêntricos nas superfícies interna da cavidade. Isso se dá em 2 estágios: no estágio I ocorre a síntese de matriz óssea, sendo que mais de $90 \%$ dessa matriz é formada por colágeno Tipo I e duas outras proteínas são formadas, a osteocalcina e a osteonectina, que se ligam aos cristais de HA. No estágio II, o osteóide recém-formado é mineralizado com cristais de HA, que contém também traços de magnésio, potássio, sódio e carbonato (NOTELOVITZ, 2001).

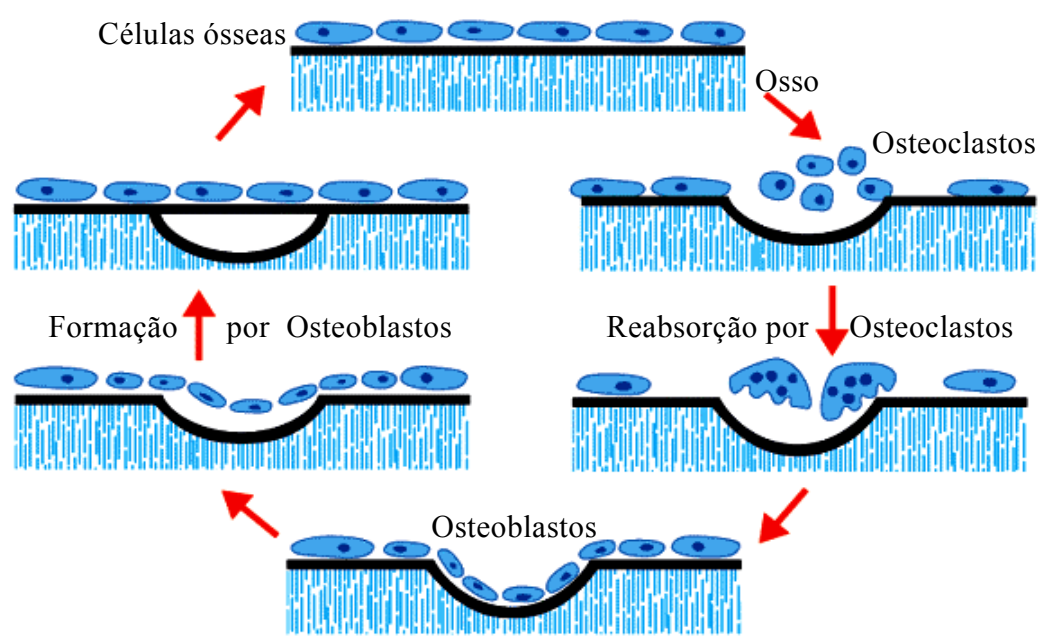

Figura 11. Esquema da ação do osteoblasto e osteoclasto na remodelagem óssea Fonte: SILVA, S. (2005) 
A velocidade de reconstrução óssea está relacionada aos níveis de fósforo e cálcio ionizados do soro, $\mathrm{pH}$ local ( $\mathrm{pH}$ baixo favorece a reabsorção mineral), PTH e níveis de calcitonina e vitamina D (WEINSTEIN; BUCKWALTER, 2000). Outros fatores podem levar à alteração na remodelagem óssea: afecções renais que elevam ou diminuem os níveis séricos; afecções endócrinas como diabetes, hipertireoidismo, hiperparatiroidismo e outras afecções relacionadas ao osso, como a osteoporose (NOTELOVITZ, 2001).

Na remodelagem, o processo biofísico para a formação de tecido ósseo apresenta como gatilho as alterações de potenciais elétricos do osso (WEINSTEIN; BUCKWALTER, 2000), assim uma corrente elétrica resultante de um esforço aplicado ao osso irá modificar o seu potencial de repouso. Dessa forma, as áreas de compressão tornam-se eletronegativas e as de descompressão, eletropositivas (Figura 12). O colágeno age como transductor, convertendo energia mecânica em elétrica, um fenômeno conhecido como piezeletricidade (WEINSTEIN; BUCKWALTER, 2000).

De forma geral, as fibrilas colágenas não-mineralizadas são carregadas positivamente, e elementos deformáveis que estão próximos a superfícies celulares são carregadas negativamente para que ocorram interações eletrostáticas. Essa relação é ideal para a regulação eletromecânica da atividade celular óssea (MARCUS; FELDMAN; KELSEY, 1996) e, como resultado final da deformação mecânica repetitiva pelas contrações musculares, há um aumento das correntes elétricas pulsáveis no osso através fenômenos piezelétricos e de fluxo (WEINSTEIN; BUCKWALTER, 2000). 


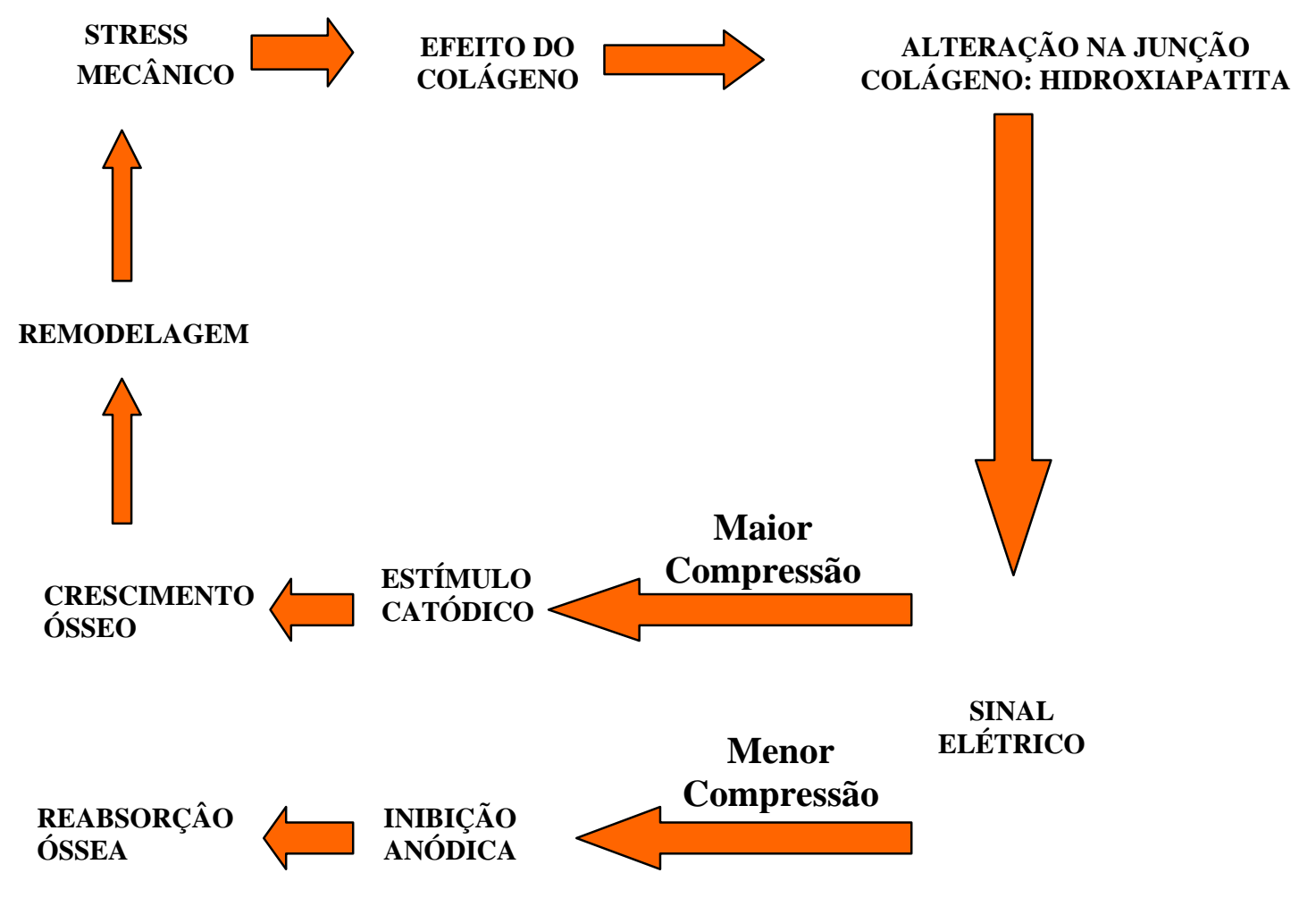

Figura 12. Representação esquemática do efeito elétrico na remodelagem.

Os fenômenos que fazem a conversão de energia mecânica em energia elétrica usando o osso como meio são de dois tipos:

* "Potencial de Fluxo": é o potencial resultante do fluxo de fluido eletrolítico produzido pela deformação do osso. Células ósseas estão em íntima comunicação entre si, através da organização estrutural do osso (canais de Volkmam), fazendo com que o osteoblasto esteja na maioria dos locais sensoriando sinais sistêmicos e transmitindo, posteriormente, para outras células no osso. Esses sinais gerados podem ser percebidos por osteócitos e sua informação reguladora é passada para o osteoblasto e osteoclasto (MARCUS; FELDMAN; KELSEY, 1996). 
* Piezeletricidade - materiais piezelétricos, incluindo o colágeno e os proteoglicanos, têm a capacidade de gerar correntes elétricas e não dependem da viabilidade tecidual (WEINSTEIN; BUCKWALTER, 2000). Esse fenômeno da piezeletricidade, que é a eletricidade resultante de uma pressão sobre os cristais, é descrito para cristais inorgânicos que não possuem em centro de simetria. Quando essa estrutura é deformada de seu estado sem compressão, a separação nos centros de cargas positivas e negativas produz uma polarização real. Inversamente, quando um campo elétrico é aplicado ao cristal produz-se uma modificação na sua forma. A formação de um potencial elétrico provém da separação de carga dentro de um material cristalino deformado (MARCUS; FELDMAN; KELSEY, 1996; WEINSTEIN; BUCKWALTER 2000).

Quando um osso longo íntegro é sujeito a uma força compressiva aplicada na direção de seu eixo longitudinal, o periósteo é induzido a proliferar e formar tecido ósseo (WEINSTEIN; BUCKWALTER, 2000). Um exemplo típico de remodelagem incompleta encontra-se nos casos de imobilização pós-traumática, em que o período prolongado de repouso leva a uma consolidação óssea retardada e à neoformação óssea enfraquecida. A contração muscular estimula o ciclo da remodelagem óssea, pois a manutenção mineral óssea e/ou a hiperplasia do osso dependem do tipo e freqüência dos exercícios e dos efeitos da gravidade. Da mesma forma, os efeitos osteogênicos são rapidamente perdidos se a intensidade e a freqüência dos exercícios diminuírem (GUYTON, 1991).

\subsection{Biomineralização}

É um processo através do qual organismos vivos constroem estruturas funcionais formadas por uma fase mineral associada a uma matriz orgânica, como ocorre nos ossos e nos 
dentes (MANN, 1989; CALVERT, 1994). Em ambos os casos, a matriz para deposição da fase mineral é o colágeno do Tipo I, que controla a cristalização, o crescimento e a orientação da fase mineral que, nesse caso é a HA, sobre sítios específicos distribuídos uniformemente sobre a matriz orgânica (MANN, 1989; CALVERT, 1994). Assim, o crescimento da fase mineral é preciso, determinado pela natureza da superfície limitante das fibrilas colágenas (MANN, 1989), dando início ou inibindo por completo a deposição de HA na formação do tecido ósseo e da dentina. Esse mecanismo complexo e desconhecido envolve proteínas ácidas presentes na MEC (MANN, 1989; CALVERT, 1994).

Os processos químicos da mineralização produzem nucleação, incorporação de cálcio e fosfato nos aglomerados de HA (KAPLAN et al., 1996) que, no início, é composta de fosfato de cálcio amorfo (não cristalino), o qual evolui à forma cristalina. Esses minerais estão incrustados na matriz intersticial juntamente com o colágeno. Os locais de nucleação sobre o colágeno são expostos e esse é um sinal para abertura dos sítios de mineralização do Gap na fibrila de colágeno. O fosfato e o cálcio tornam-se ligados a esses locais e, a partir desses aglomerados iniciais de íons, segue-se o crescimento da fase mineral em áreas periódicas específicas nas fibrilas colágenas. Os cristais de HA continuarão a crescer na presença de adequada quantidade de íons cálcio e potássio. (KAPLAN et al., 1996; WEINSTEIN; BUCKWALTER, 2000).

Embora o colágeno do Tipo I esteja distribuído em todo organismo, sua mineralização (Figura 13), além do tecido ósseo e dentes, só ocorre em outros tecidos em condições patológicas, como na calcificação de válvulas cardíacas biológicas e metaplasia óssea (MANN, 1989; CALVERT, 1994). Outros desequilíbrios nos mecanismos que mantêm essas estruturas mineralizadas resultam em doenças, tais como a osteoporose, a aterosclerose, a formação do cálculo renal e a desmineralização dos dentes (MANN, 1989; CALVERT, 1994). 
Por isso que o conhecimento desses mecanismos associados à mineralização pode contribuir significativamente para o tratamento de tais doenças.
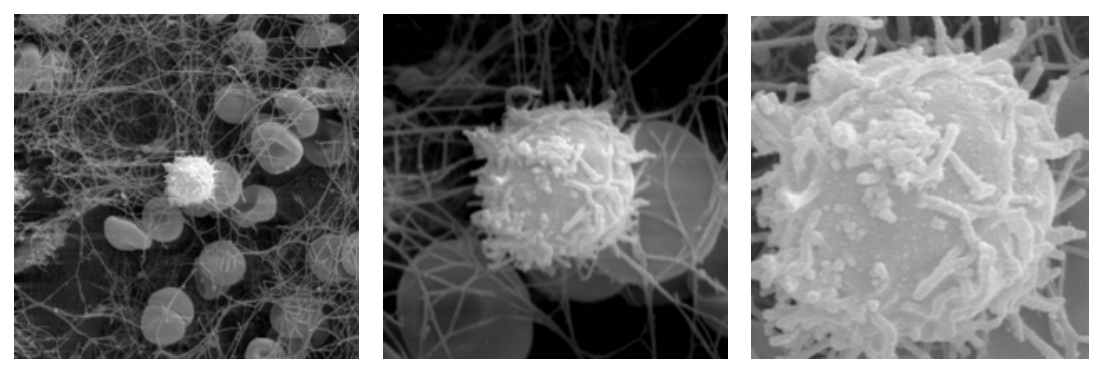

Figura 13. Micrografia de Microscopia Eletrônica de Transmissão de osteoblasto ativo produzindo fibras de colágeno mineralizada após 14 dias de implantação matriz tridimensional de colágeno. Fonte: GOISSIS, G. ; MAGINADOR, S.; MARTINS, V. (2003)

\subsection{Adesão celular e a transducção de sinal}

Nas últimas três décadas, a Biologia tem avançado significativamente no entendimento dos mecanismos que controlam o comportamento celular relacionado aos estímulos provenientes da MEC (LANGER et al., 1990; LANGER, VACANTI, 1993; DEUEL, 1997; LANZA; LANGER; CHICK, 1997), que resumidamente são (Figura 14):

a) A célula interage com o meio externo por meio de proteínas presentes na membrana celular, cuja função é intermediar a transposição de informações originadas na MEC para seu interior.

b) Muitas dessas proteínas são receptores, caracterizados por um domínio para a ligação com a MEC acoplada a um sistema de sinalização que regula ou modifica a atividade celular. 
c) Quando um receptor acopla ao seu ligante específico (normalmente uma proteína ou um peptídeo), como resposta a alterações conformacionais do receptor ou afinidade por outras macromoléculas celulares, a célula inicia uma reação em cascata intermediada por enzimas, resultando na amplificação do sinal, um processo denominado de transdução de sinal (LAUFENBURGER; LINDERMAN, 1993).

d) A transdução de sinal afeta a regulação dos genes, controlando, portanto, funções celulares que incluem a sobrevivência, a proliferação, a migração e a diferenciação.

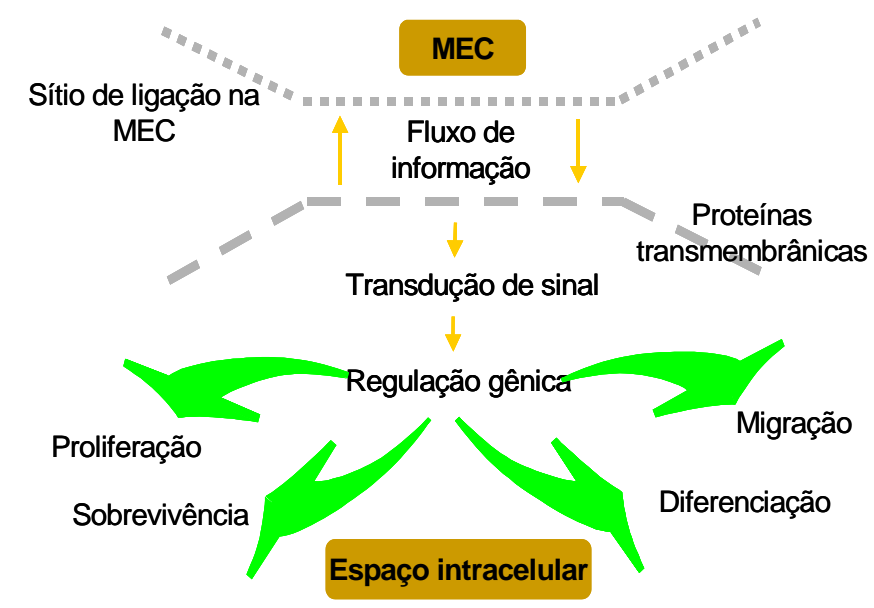

Figura 14. Esquema da transdução de sinais provenientes da Matriz Extracelular para o interior da célula

Fonte: SILVA, S. (2005)

Outro exemplo clássico do controle de fatores externos sobre a fisiologia celular e, conseqüentemente, sobre o comportamento do tecido, é a remodelagem do osso (BASSET, 1965) regulado pelas pressões externas exercidas sobre o mesmo (Figura 14), que depende essencialmente de:

a) Modulação da atividade celular por estímulos externos. Nesse caso, estímulos mecânicos que agem sobre correntes elétricas resultantes da variação de potenciais de fluxo e 
da piezeletricidade (POLLACK, 1984). Nas zonas de maior compressão (potencial negativo) ocorre a formação do tecido ósseo e a reabsorção nas zonas de menor compressão (potencial positivo).

b) Como conseqüência desses efeitos, osteoblastos e osteoclastos que interagem com uma seqüência de aminoácidos Arg-Gly-Asp (RGD) localizada na MEC (HEINO, 2000) iniciam o processo de construção e reconstrução, a Remodelagem.

O organismo humano é constantemente sujeito ao stress mecânico externo (da gravidade e movimentos), bem como forças internas (contração e hemodinâmica) geradas tanto por músculos como células não musculares. Essas forças são importantes para a homeostase do tecido ósseo; na sua recuperação, por exemplo, as trabéculas são remodeladas por seguir as alterações de tensão e linhas de compressão. O efeito da diminuição ou aumento do stress mecânico leva a uma mudança total no metabolismo celular (CHIQUET, 1999).

Outro exemplo desse efeito de estímulos externos sobre a físiologia celular é o das correntes elétricas, que aumentam significativamente a velocidade de crescimento do osteoblasto (WIESMANN et al., 2001).

São as integrinas, proteínas diméricas, que fisicamente ligam a MEC ao citoesqueleto e acredita-se que, devido à sua localização estratégica, elas possam sensoriar essas mudanças na tensão superficial da célula e transmitem, por uma ação mecânica, forças entre interior e exterior das células em ambas as direções (HEINO, 2000). Em um estado de equilíbrio, forças externas (elásticas) e internas (citoesqueleto) estão balanceadas e a sinalização via integrina no contato célula-MEC é considerada equivalente (HEINO, 2000). Um exemplo disso é o que se observa no fibroblasto (Figura 15), no caso, se o seu substrato é alongado, uma resultante de forças positivas age no contato célula-MEC e integrinas sinalizam para o núcleo 
(CHIQUET, 1999). Como efeito, há um aumento da produção protéica da MEC e uma diminuição da expressão da colagenase. A célula logo tentará reduzir o stress e procura um novo equilíbrio para a reestruturação do contato do citoesqueleto à MEC. Se o seu substrato é relaxado ou comprimido, a tensão interna do citoesqueleto é aumentada e ele contrai. Isso pode disparar vários sinais, resultando em um modelo revertido da expressão de proteína (CHIQUET, 1999; HEINO, 2000).

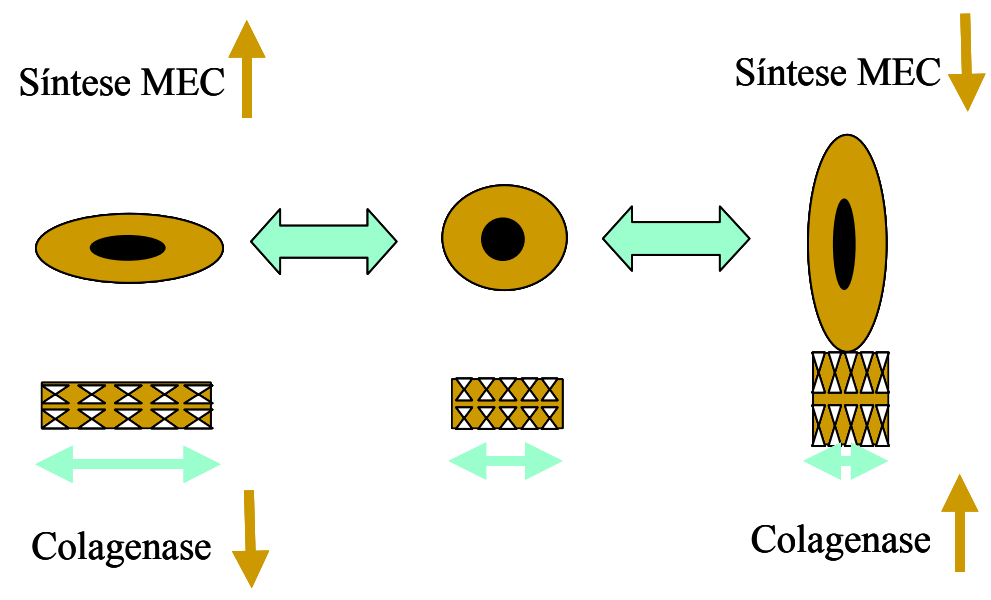

Figura 15. Modelo para alterações da atividade celular do fibroblasto em função de tensões aplicadas sobre a Matriz Extracelular Fonte: SILVA, S. (2005)

Uma das implicações clínicas desses conhecimentos de adesão celular está relacionada aos processos de mutações e "ageing". Como mencionado anteriormente, modificações no comportamento celular têm origem também nas alterações genéticas da MEC, principalmente do colágeno, e que resultam em doenças de gravidade variável (cf. Database of human type I and type III collagen mutations, 2003). A etiologia dessas doenças está relacionada às variações na estrutura do próprio colágeno ou alteração da sua interação com pelo menos 50 moléculas biológicas, que contribuem para a manutenção da integridade dos tecidos (cf. Human protein human protein reference Database, 2003). 


\subsection{Ageing}

O termo "ageing" aplica-se a todas as alterações da MEC decorrentes do aumento da idade (BAILEY, 2001), as quais resultam de reações químicas nas cadeias laterais de aminoácidos (Figura 16), como Arginina [Arg, doravante], Lisina [Lys, doravante] e Ácido Aspártico [Asp, doravante].<smiles>NC(CC(=O)O)C(=O)O</smiles>

Asp<smiles>NC(=O)CC(N)C(=O)O</smiles>

Asn<smiles>NCCCCC(N)C(=O)O</smiles>

Iys<smiles>N[C@@H](CCC(=O)O)C(=O)O</smiles>

Glu<smiles>NC(=O)CCC(N)C(=O)O</smiles>

Gln<smiles>N=C(N)NCCCC(N)C(=O)O</smiles>

Arg

Figura 16. Estruturas químicas dos aminoácidos: Acido Aspártico, Acido Glutâmico, Asparagina, Glutamina, Lisina e Arginina.

As alterações do "ageing" no tecido são lentas (leva meses, ou mesmo anos) e, dessa forma, são susceptíveis às mudanças relacionadas à idade (BAILEY; PAUL; KNOTT, 1998) e, como conseqüência, vários efeitos danosos podem ocorrer, entre eles, a redução na renovação celular e a perda das propriedades físicas dos tecidos, o que diminui a sua flexibilidade e permeabilidade devido às ligações cruzadas intermoleculares e modificações da cadeia lateral do colágeno. Essas mudanças típicas são aceleradas no indivíduo diabético 
devido à hiperglicemia e é a maior causa de morbidade e mortalidade nesses sujeitos (BAILEY, 2001).

Várias doenças relacionam-se ao "ageing”, dentre elas, o diabete (ULRICH; CERAMI, 2001), a aterosclerose (REKHTER, 1999) e a osteoporose (BAILEY; PAUL; KNOTT, 1998).

Os efeitos do "ageing" acometem todo o organismo, uma vez que as mudanças ocorrem na estrutura da proteína mais abundante do corpo humano - o colágeno. Entre os processos que se modificam com o envelhecimento do colágeno podemos citar: a variação da composição do tecido envolvendo alteração na proporção de diferentes colágenos em um tecido particular; a variação na qualidade do metabolismo do colágeno, embora a porcentagem de renovação celular total seja comparativamente baixa, pois a síntese de colágeno diminui regularmente com a maturação e, por outro lado, a degradação do colágeno aumenta (BAILEY, 2001).

Como citado anteriormente, a perda da flexibilidade dos tecidos está relacionada às ligações cruzadas do colágeno, o qual provê força estrutural e forma ao tecido. (BAILEY; KNOTT, 1999). Segundo Kaplan (1996), as moléculas de tropocolágeno se agregam espontaneamente para formar microfibrila (Figura 17), que tem pequena força tensil até que se formem ligações cruzadas entre as moléculas adjacentes do tropocolágeno (ligações cruzadas intermoleculares) e entre microfibrilas adjacentes (ligações cruzadas intramoleculares). 


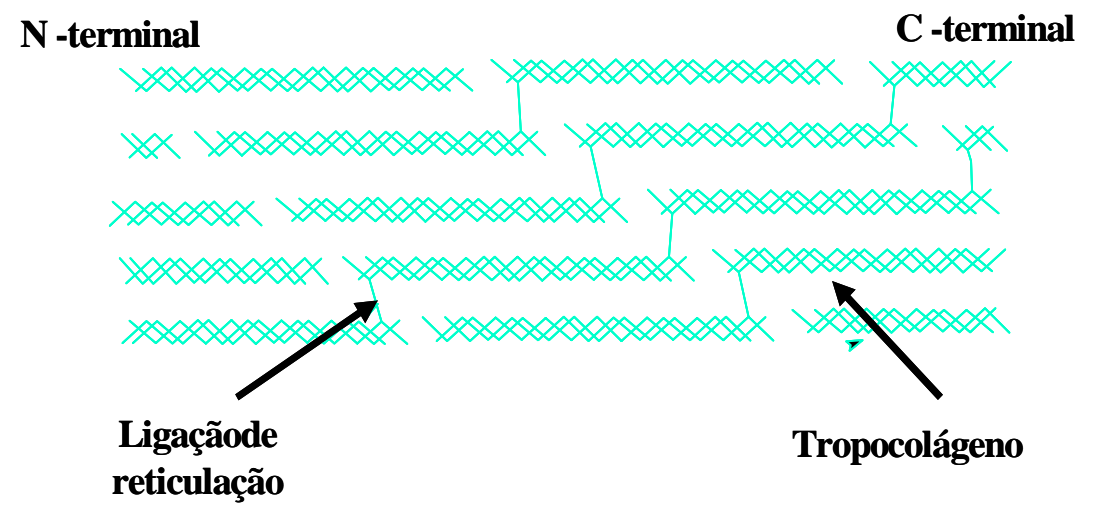

Figura 17. Esquema dos locais de formação de ligações cruzadas em matrizes colagênicas no "ageing" Fonte: SILVA, S. (2005)

A formação das ligações cruzadas envolve 2 tipos diferentes de mecanismos: um processo enzimático durante o desenvolvimento e maturação e um processo não enzimático extrínseco com glicose (BAILEY, 2001). São essas ligações cruzadas que se encontram mais diretamente relacionadas ao processo de "ageing", alterando as propriedades do colágeno e repercutindo em doenças como a osteoporose.

Uma modificação incomum do colágeno que ocorre com o aumento da idade é o aumento da isomerização (Figura 18) e racemização de resíduos de aspartil. Em tecido ósseo, a ß-isomerização de Asp-Gly foi originalmente mostrada em N-telopeptídeodo colágeno Tipo I. Essa modificação foi determinada pela análise direta de aminoácido no tecido e também na urina, concluindo-se que a extensão de isomerização aumenta com a idade (BAILEY, 2001).

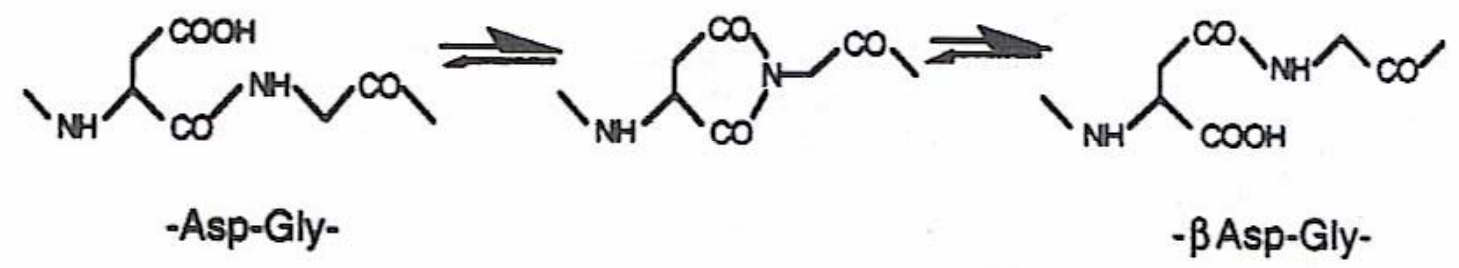

Figura 18. Esquema químico da Isomerização Fonte: BAILEY A. J.(2001) 


\subsubsection{Processo enzimático de formação de ligações cruzadas}

O mecanismo de ligações cruzadas decorrente de enzima (Figura 19), a lisil oxidase, irá transformar as Lys de N- e C-telopeptídeos em lisil aldeido (BAILEY, 2001); essa é uma reação que leva ao aumento de ligações cruzadas de natureza covalente entre triplas hélices adjacentes na forma de base de Shiff (BAILEY; PAUL; KNOTT, 1998).

No início, formam-se as ligações cruzadas divalentes tipo Keto-amina entre um lisilaldeido no telopeptídeo e um resíduo de Hyl na região helicoidal. Contudo, essas ligações cruzadas tendem a diminuir com a idade, submetendo as reações para formar a trivalente ligação cruzada do tipo Piridinolina (BAILEY; KNOTT, 1999). No tecido ósseo, esse tipo de ligação cruzada forma-se de forma escassa, ou seja, enquanto a ligação cruzada do tipo Ketoamina apresenta-se numa freqüência de 1 por molécula de colágeno, a de Piridinolina apresenta-se inferior ou igual a uma por cinco moléculas de colágeno (BAILEY, 2001). Essa dificuldade de conversão de Keto-amina em Piridinolina pode ser compensada por uma outra ligação cruzada, que seria a trivalente ligação cruzada de Pirrole (BAILEY; PAUL; KNOTT, 1998).

Comparando as 2 ligações cruzadas trivalentes derivadas da Keto-amina, podemos dizer que a do tipo Piridinolina são ligações cruzadas intramoleculares e necessitam alta hidroxilação de Lys no telopeptídeo, enquanto na reação de Pirrole formam-se ligações cruzadas intermoleculares, necessitando de baixa hidroxilação de Lys no telopeptídeo (BAILEY; KNOTT, 1999).

Essa diferença no tipo de ligação cruzada na fibrila tem repercussões sobre a propriedade mecânica da fibra. Segundo Knott (1995), no caso do tecido ósseo, estudo tem mostrado que as propriedades mecânicas do osso relacionam-se mais com a concentração de 
Pirrole do que com o conteúdo de Piridinolina, uma vez que essa última forma ligações cruzadas intramoleculares, as quais conferem menor estabilidade ao colágeno em comparação com as ligações cruzadas intermoleculares de Pirrole.

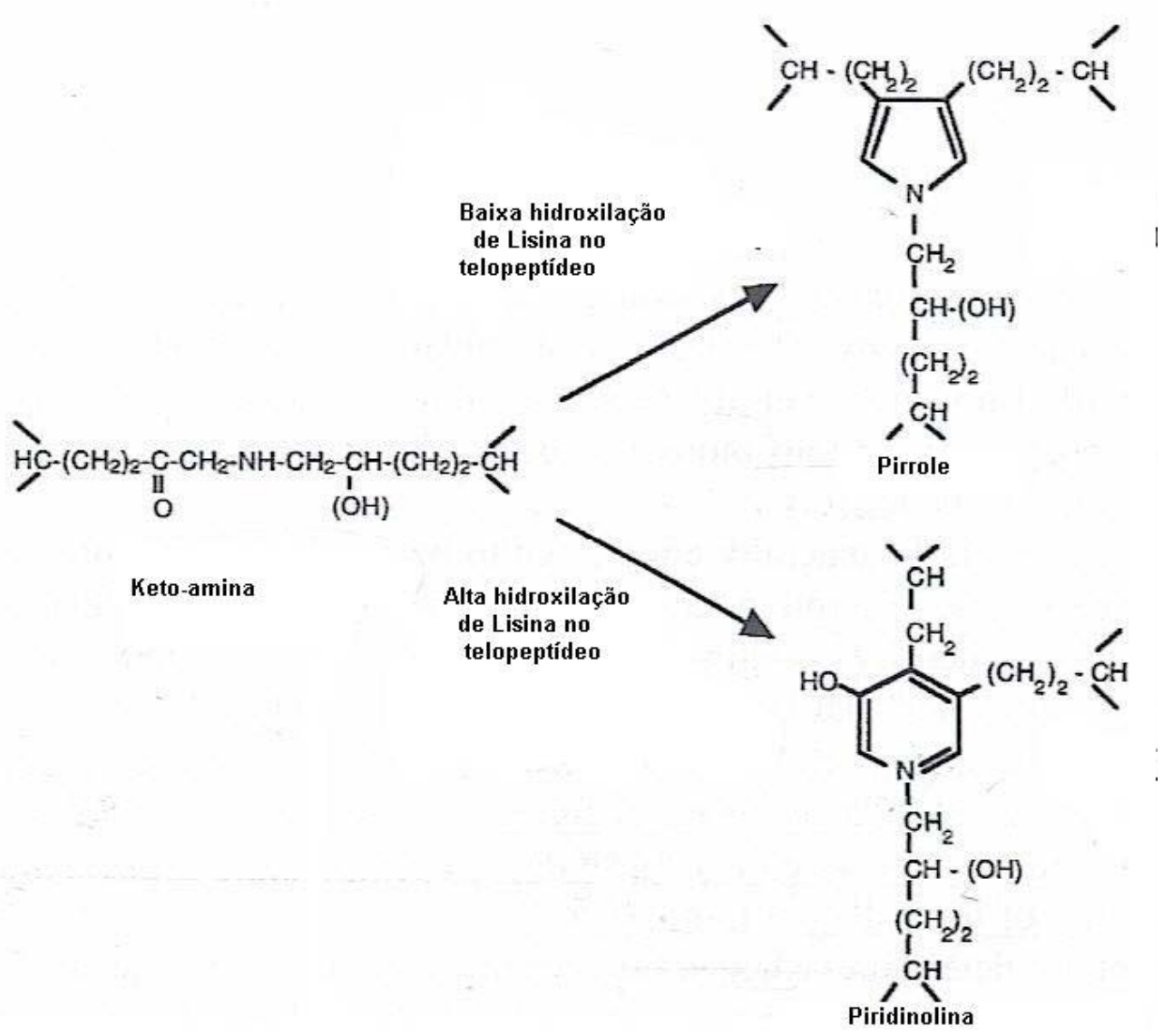

Figura 19. Esquema químico do processo enzimático de formação de ligação cruzada. Fonte: BAILEY A. J.; KNOTT L. (1999)

\subsubsection{Processo não-enzimático de formação de ligações cruzadas}

Outro processo não-enzimático de formação de ligações cruzadas e que ocorre uma vez que a porcentagem de turnover do colágeno se reduz com a maturação (Figura 20), envolve uma reação adventícia de glicose com Lys e Arg da cadeia lateral no colágeno 
(BAILEY, 2002). Esse processo é conhecido como glicação e leva a ligação cruzada intermolecular.

Nesse processo, a glicose reage com o $\varepsilon$-amino grupo de Lys para formar o GlucosilLisina, mas essa reação é muito lenta e outro açúcar reage de forma mais rápida, mas está presente geralmente em concentrações muito baixas, a ribose, ou metabólicos, como o metilglioxal. Uma vez formado, o hexosil-lisina é estabilizado pela espontânea reação de Amadori para formar as Keto-aminas, as quais reagem posteriormente, submetendo-se a modificações oxidativas, finalmente resultando na formação do AGEs (Advantaced Glycation End-Products), termo que descreve o produto final formado após a instável base de Shiff. Um AGE pode ser submetido a uma série de reações complexas para formar uma ligação cruzada intermolecular como a pentosidina ou ao processo de base de Shiff para formar carboximetillisina. Essa complexa reação pode chegar da quebra oxidativa da hexosil-lisina para produzir um açúcar mais reagente, como o 3-deoxiglicosone ou glioxal, o qual pode então se unir a outro aminoácido da cadeia lateral (BAILEY, 2001).

Resumidamente, na glicação há modificações da cadeia lateral do aminoácido por reação de glicose tanto com Lys para formar carboximetil-lisina, como dos metabólitos da glicose com Arg para formar imidazolone. Isso claramente altera o padrão de carga da molécula, levando a mudanças na interação célula: colágeno ou subseqüente remodelação do colágeno. A modificação da Arg é particularmente importante porque o local de ligação ArgGly-Asp [RGD, doravante] é envolvido no local de reconhecimento para duas integrinas $\alpha^{1} \beta^{1} \mathrm{e}$ $\alpha^{2} \beta^{1}$, as quais fazem ligação física entre a célula e a matriz (BAILEY; PAUL; KNOTTL, 1998). 


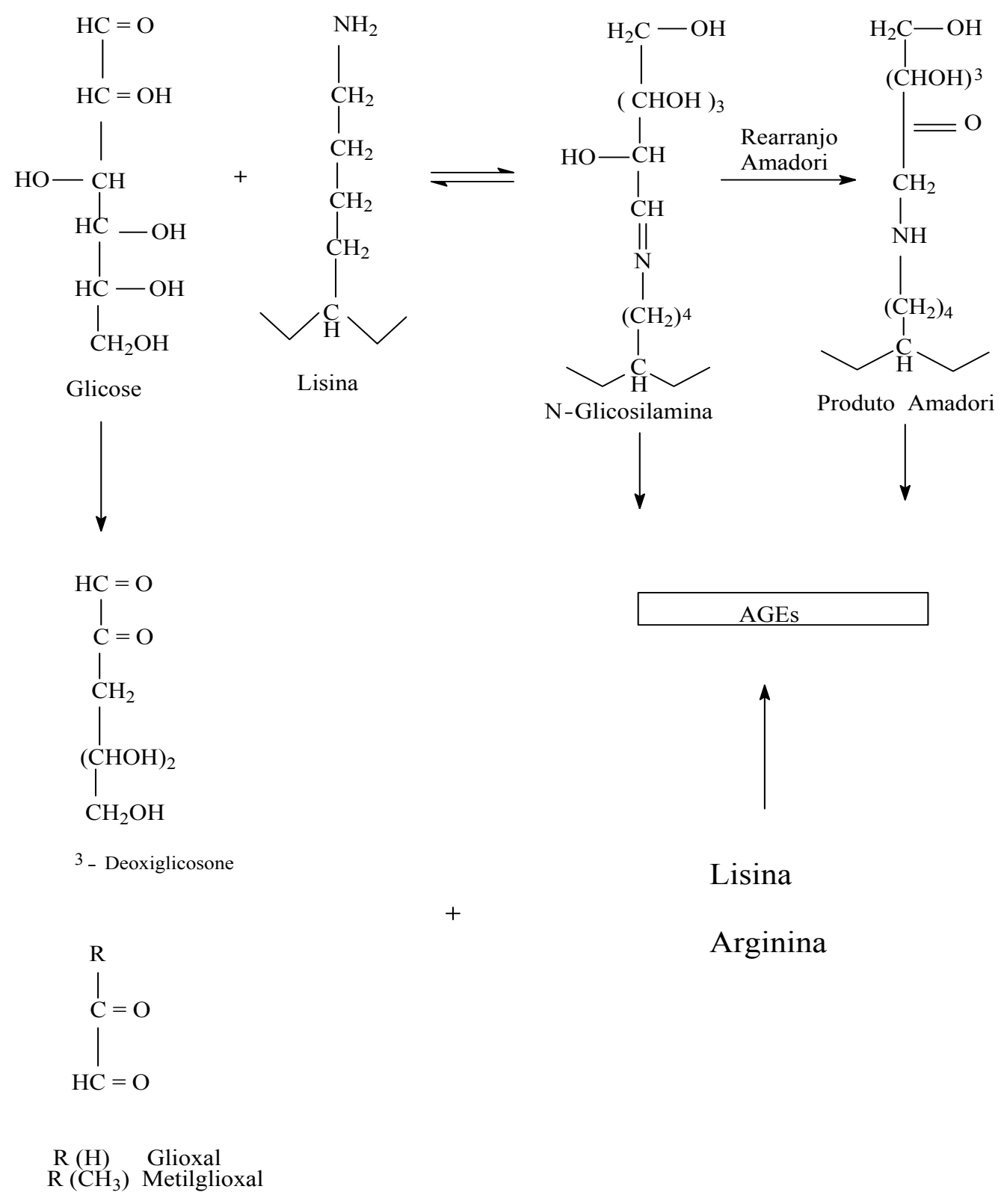

Figura 20. Esquema químico da Glicação.

Fonte: BAILEY A.J. (2001)

\subsubsection{Alterações do "ageing" no tecido ósseo e sua repercussão na osteoporose}


Com a maturação e envelhecimento do tecido ósseo, muitas mudanças podem ser observadas como a diminuição da deformação plástica e o acúmulo de microdanos, o que tem um efeito na propriedade do tecido ósseo e no risco de fratura (BURR, 2002). O colágeno é o principal opositor a esses danos e acredita-se que as ligações cruzadas intramoleculares aumentam a dureza do tecido ósseo.

Com a idade, há uma diminuição no conteúdo de colágeno, sem haver, contudo, nenhuma mudança bioquímica na sua natureza (em particular, no nível de hidroxilação de Lys e natureza das ligações cruzadas), quando comparado ao osso do adulto jovem. Esta diminuição está associada a um aumento na proporção de tecido mineralizado. Contudo, a estabilização das ligações cruzadas pode mudar com a idade e isso tem um efeito na fragilidade óssea (BAILEY; KNOTT, 1999). Essa aparente fragilidade decorrente das alterações nas ligações cruzadas inter e intramoleculares podem levar a um desarranjo dentro da fibra.

Há também uma maior porosidade desse tecido, aumentando a sua mineralização e as suas propriedades mecânicas, o que diminui a absorção de energia nesse tecido (BURR, 2002). Contudo, a resistência óssea relaciona-se a esse aumento da mineralização, pois o tecido ósseo hipermineralizado se torna quebradiço, o que acumula microdanos (SCHAFFLER ; CHOI ; MILGROM, 1995).

Além disso, segundo Burr (2002), há também mudanças na morfologia da porção mineral do tecido ósseo, uma vez que os cristais apresentam-se mais esféricos, embora o seu tamanho mude muito pouco. Acredita-se que essa mudança na morfometria dos cristais interfere no local de distribuição do stress no tecido e em sua capacidade de suportar cargas.

Considerando que o tecido ósseo é de natureza dinâmica, sendo constantemente removido e produzido no turnover normal, é crucial que a estrutura do novo colágeno recolocado antes da calcificação seja idêntica ao colágeno pré-existente, porque uma 
modificação na estrutura do colágeno poderia resultar em uma estrutura enfraquecida e de pobre mineralização (BAILEY; KNOTT, 1999).

Em resumo, dentre as modificações decorrentes no processo de "ageing", envolvendo tanto a porção orgânica quanto mineral do tecido ósseo, com diminuição do conteúdo de colágeno, aumento de sua mineralização, aumento da sua porosidade e alteração da morfologia dos cristais (BURR, 2002). Acredita-se que, dentre essas alterações, as mais importantes do ponto de vista estrutural são aquelas que envolvem alteração dos aminoácidos pela reação de Glicação, principalmente da Arg, pois afeta a interação célula/matriz, levando a mudança nos sítios de adesão celular, o que altera o colágeno nativo (BAILEY; KNOTT, 1999). De qualquer forma, o declínio na propriedade funcional do tecido ósseo é crucial para a estrutura do tecido, pois o colágeno residual não se mostra idêntico ao colágeno ósseo original (BAILEY; KNOTT, 1999). Essa alteração do colágeno repercute e influencia na fisiopatologia de várias doenças, como por exemplo, a osteoporose.

$\mathrm{Na}$ osteoporose, não há alteração na concentração de colágeno; contudo, há uma diminuição nas ligações cruzadas redutíveis (BAILEY, 2002). Dessa forma, as alterações do "ageing" não estão relacionadas somente ao processo de Glicação, mas também ao aumento de hidroxilação de Lys nas fibras colágenas (BAILEY; PAUL; KNOTT, 1998; BAILEY; KNOTT, 1999; BAILEY, 2001), o que altera o sistema de remodelagem e mineralização. Estes se tornam ineficientes devido à falta de adesão de osteoblastos e osteoclastos sobre as seqüências do tipo RGD, como também em virtude da falta de estrutura física das fibras colágenas para permitir a inclusão da HA (PAUL; BAILEY, 1999).

Segundo Bailey (2001), a hidroxilação da Lys alterou o tipo de ligação cruzada presente no colágeno. Em particular, notou-se um aumento de $40 \%$ na hidroxilação dos resíduos de Lys e uma diminuição no nível de ligações cruzadas imaturas no colágeno recentemente formado. Ao contrário do que se esperava, surpreendentemente, os níveis de 
ligação cruzada madura de Piridinolina manteve-se constante, mas a ligação de Pirrol, biomecanicamente mais importante, diminuiu significantemente.

Esse aumento da hidroxilação, que foi surpreendentemente confirmado na cadeia $\alpha^{2}$, aumenta a atividade da lisil hidroxilase, retardando a formação da tripla hélice, ou resultando na perda de proteínas específicas que devem ser envolvidas na sua formação e também na alteração ou redução das ligações cruzadas, o que, como conseqüência, leva a um aumento na fragilidade do osso (BAILEY; KNOTT, 1999).

Dessa forma, como já foi dito em relação à osteoporose, a resistência óssea não pode ser predita exatamente por uma simples avaliação da massa óssea, sustentando a controversa de que há de fato uma diferença no colágeno nativo no tecido ósseo. Essa diminuição da densidade óssea relaciona-se à perda total de osso, mas a diferença entre baixa densidade e susceptibilidade a fraturas deve ser devido à modificação da estrutura do colágeno. Muitas mudanças bioquímicas na natureza do colágeno estão relacionadas mais à própria doença do que com a idade (BAILEY; KNOTT, 1999).

Dessa forma, este estudo relaciona a osteoporose a mudanças no metabolismo do colágeno ósseo decorrente do processo de envelhecimento do organismo, resultando na formação de uma fibra colágena modificada comparada à produzida no turnover normal. Tudo isso, somado aos outros fatores etiológicos, como alterações endócrinas, desnutrição, fatores genéticos, imobilidade, entre outros, espera-se que o tecido ósseo apresente-se estruturalmente fragilizado, de pobre mineralização e que possua uma remodelagem ineficiente. 


\section{OBJETIVOS}

Relacionar o colágeno Tipo I ao processo de "ageing", através de um mecanismo baseado na mudança da topografia dos aminoácidos, principalmente no intervalo 70-110 do período D, região da junção Overlap:Gap. Essa mudança descreve o seu papel como componente de alteração da mineralização do tecido ósseo, repercutindo no seu gatilho, o que influencia na patologênese da osteoporose. 


\section{MATERIAL E MÉTODO}

2

3 Bescrição do mapa de distribuição da estrutura primária das cadeias alfa que formam a microfibrila de acordo com o modelo de Smith

Segundo Chapman, Tzaphlidou e Meek (1990), observado as fibrilas de colágeno após impregnação com sais de metais pesados na MET, essas se caracterizam pela presença repetitiva de zonas diferentes que formam a unidade estrutural do colágeno (período D). $\mathrm{Na}$ coloração negativa da MET podem-se observar as zonas claras (Overlap) e as zonas escuras (Gap). Com a coloração positiva da MET, observa-se que, independentemente da região do Overlap e Gap, as fibrilas do colágeno são caracterizadas também por uma subperiodicidade, refletindo a regularidade e a periodicidade da distribuição dos aminoácidos ácidos e básicos presentes na estrutura fibrilar.

O esquema abaixo mostra o modelo pentafibrilar de Smith, em que a microfibrila de colágeno é formada por 5 moléculas de colágeno que se sobrepõem e se encontram alternadas de $1 / 4$ de seu comprimento. 


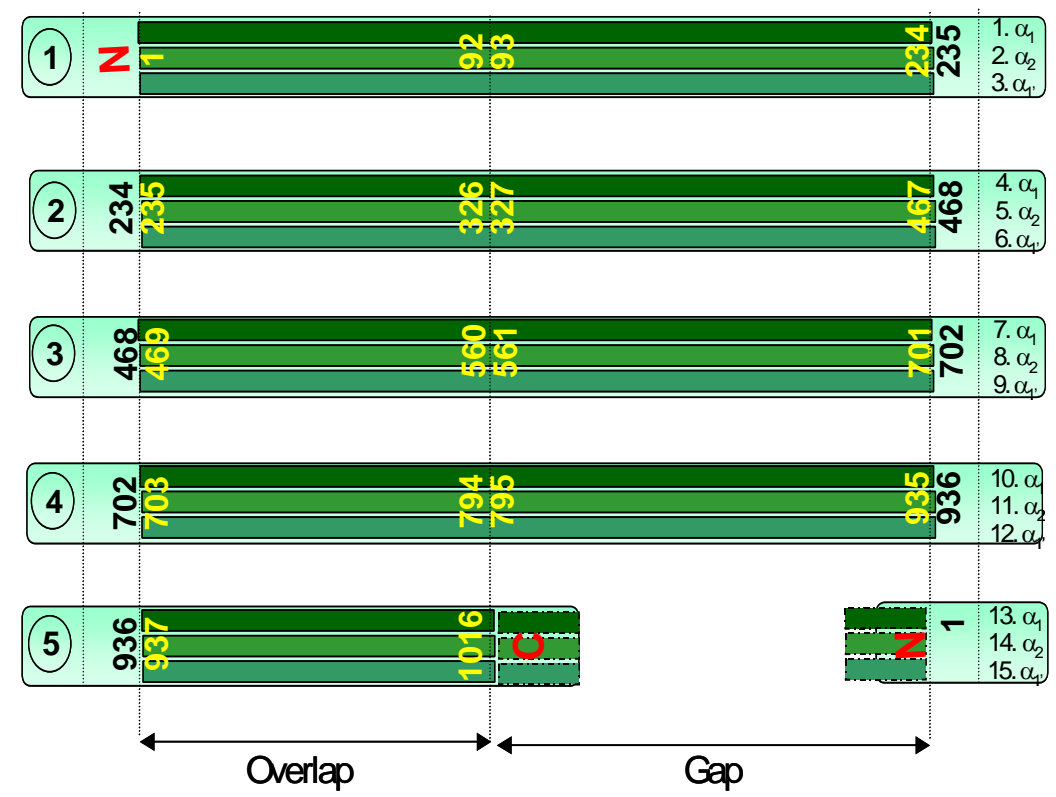

Esquema demonstrativo da estrutura primária dos resíduos de aminoácidos e a definição dos intervalos das zonas do Overlap e Gap, formando um período D com 234 aminoácidos. Os números referem-se à posição do aminoácido na molécula com a repetição Gly-X-Y. Os números nos círculos referem-se à posição da cadeia alfa na microfibrila. Os números em círculos definem a posição da molécula em relação ao plano que se alinha com o cristal.

\section{Características}

1. A estrutura primária das cadeias $\alpha^{1}$ e $\alpha^{2}$ estão alinhadas segundo o Modelo Pentafibrilar quarto alternado de Smith.

2. Na representação no plano, as cadeias que formam a tripla hélice estão deslocadas da esquerda para a direita, de resíduo ao longo do eixo maior da microfibrila. Essa representação se dá porque na molécula de colágeno os aminoácidos, na sua descendência e ao longo do eixo maior, estão deslocados um do outro de $120^{\circ}$. 
3. Da esquerda para a direita, os resíduos de aminoácidos são mostrados do Npara o C-terminal.

4. Localização das zonas Gap e Overlap e sua sub-periodicidade a, b, c, d e tem a orientação do C-para o N-terminal.

A planilha integral encontra-se no Anexo I e dela foram tirados todos os dados para as construções de gráficos individuais dos resíduos de aminoácidos ácidos, básicos e hidrofóbicos.

Todos os gráficos foram construídos com o auxílio do programa Origin 6.0 e em todos foram aplicados a mesma normalização de curva (Smooting, FFT 7). Esse valor foi escolhido porque reduz a resolução ao longo do período a $2 \mathrm{~nm}$, um valor comparável com aqueles obtidos pelas técnicas de microscopia (CHAPMAN; TZAPHLIDOU; MEEK, 1990).

Abaixo segue um modelo com parte da planilha de distribuição de aminoácidos que compõem a estrutura primária do colágeno Tipo I segundo modelo Pentafibrilar de Smith e de acordo com a convenção de Chapman (CHAPMAN; TZAPHLIDOU; MEEK, 1990). 


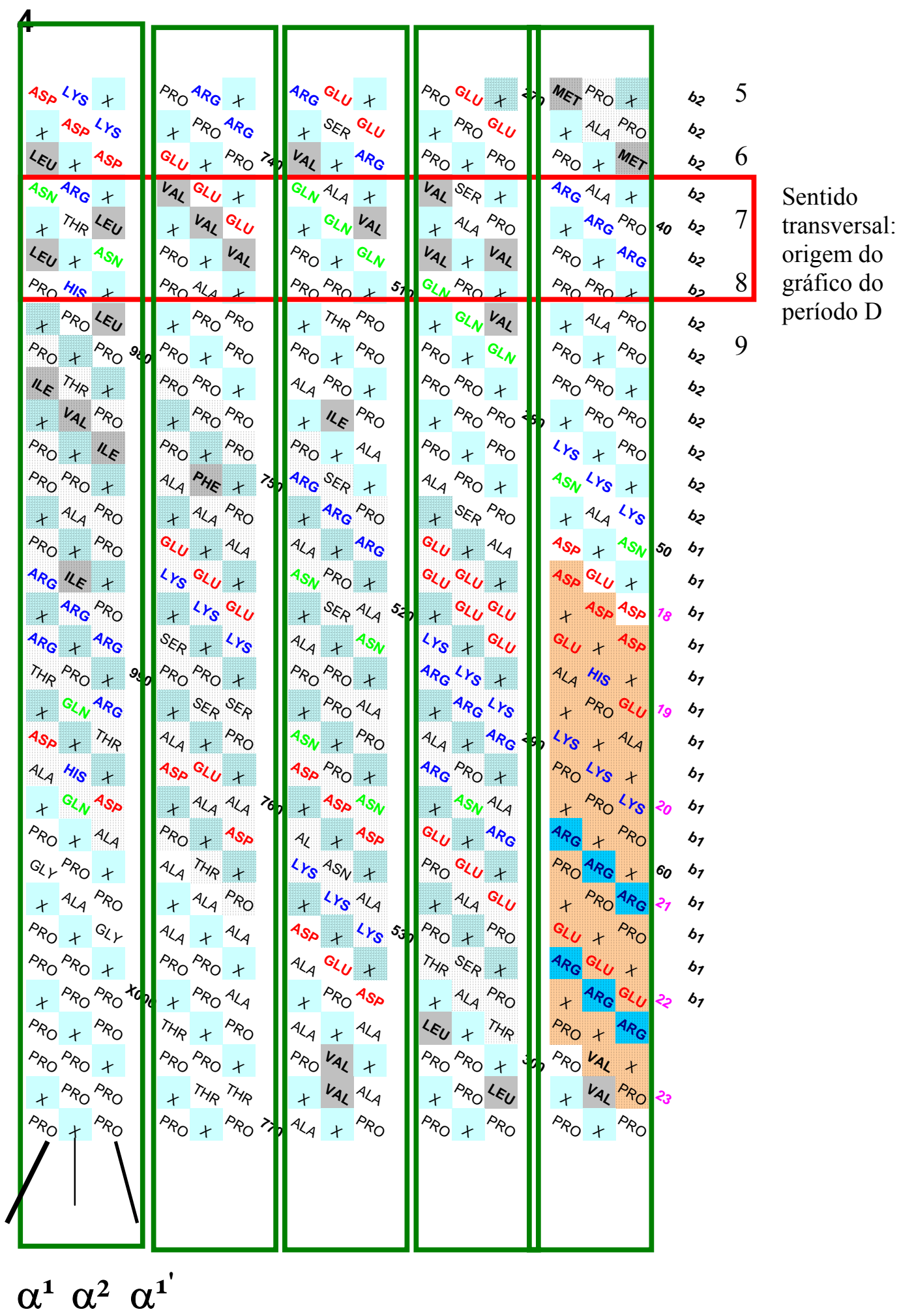
5
4
3
2
1

Triplas hélices: origem aos gráficos ao longo das cadeias $\alpha$ 


\section{RESULTADOS E DISCUSSÃO}

Osteoporose é uma doença osteometabólica comum, que leva à modificação na estrutura trabecular do tecido ósseo, deixando-o mais frágil e, como conseqüência, há aumento do risco de fraturas, mesmo na ausência de traumas significantes (WEINSTEIN; BUCKWALTER, 2000). Embora sua etiologia seja complexa, um aspecto intimamente relacionado à osteoporose é a alteração química que ocorre, principalmente, nas cadeias laterais dos aminoácidos que participam da matriz colagênica resultante do processo de "ageing", levando à mudança na característica estrutural da matriz. Em resumo, estas reações são:

1 - Aumento de hidroxilação de resíduos de Lys que ocorre primariamente na cadeia $\alpha^{2}$, tem como conseqüência o retardo na formação da tripla hélice, resultando na alteração do processo de fibrilogênese e redução da estabilização das fibras por alteração nas ligações cruzadas (KNOTT et al., 1995).

2 - As alterações da matriz colagênica são introduzidas pelas reações de glicação, com subseqüente alteração da estrutura da cadeia lateral de aminoácidos, envolvendo os resíduos de Arg e Lys, os quais estão envolvidos nos "motifs" de adesão celular (BAILEY; PAUL; KNOTT, 1998), tais como a seqüência Arg-Gly-Asp (RGD), sítio de ligação do osteoblasto (BAILEY, 2001). Sem essa adesão, vários mecanismos encontram-se prejudicados, mas o que mais influi é a remodelagem do tecido ósseo. 
3- Além disso, o aumento das reações de isomerização e racemização de resíduos de Asp, associados ao processo de glicação, levam a mudanças que promovem alterações das propriedades químicas, físicas e fisicoquímicas.

Outro aspecto que pode estar relacionado à alteração da matriz colagênica e que pode influenciar na fisiopatologia da osteoporose é o processo de biomineralização, pois, para que ocorra a deposição orientada de HA sobre as fibras de colágeno, é necessário que essas forneçam suporte físico. Contudo, com a diminuição na resistência estrutural do colágeno conseqüente do aumento de hidroxilação de Lys, as fibras encontram-se estreitadas em diâmetro e isso altera a capacidade de mineralização do tecido ósseo na osteoporose (KNOTT et al., 1995). Evidências similares dessa alteração são encontradas em outras patologias, como na Osteogênise Imperfeita, segundo Kirsche et al.(1981, apud KNOTT et al., 1995)³. Além desse fato, essa mineralização alterada encontra-se baseada diretamente na localização precisa dos aminoácidos da fibrila de colágeno. Por isso, tentativas de correlacionar o processo de biomineralização do colágeno do Tipo I com a topografia dos aminoácidos, principalmente com a distribuição dos polares carregados e hidrofóbicos, foram sempre realizadas com suas distribuições ao longo do período D (MAITLAND; ARSENAULT, 1991).

Embora essa distribuição mostre que, ao longo do eixo transversal do período D, esses aminoácidos estejam concentrados em regiões preferenciais, o crescimento dos cristais na direção do eixo maior do período D sugere a importância da existência de uma distribuição regular dos aminoácidos polares, bem como dos hidrofóbicos, pelos motivos descritos a seguir:

\footnotetext{
${ }^{3}$ KIRSHE, E. et al. (1981) Jornal Clinical Investigation v.11 , p.39-47 apud In: KNOTT, L. et al. (1995). Biochemical changes in the collagenous matrix of osteoporotic avian bone. Biochemical Journal, Great Britain, v.310, p.1045-1051.
} 
1. O crescimento dos cristais de HA na zona Gap ocorre ao longo do eixo longitudinal da fibrila de colágeno (WEINER; TRAUB, 1986; BENIASH et al., 2000), pressupondo um ordenamento de sítios de interação na mesma direção.

2. O processo de biomineralização do colágeno deve envolver a participação de Asp e Glu estrategicamente dispostos na estrutura primária das cadeias $\alpha$, principalmente na zona do Gap, onde tem início o processo de biomineralização (WEINER; TRAUB, 1986; MAITLAND; ARSENAULT, 1991; BENIASH et al, 2000). Em outros sistemas de biomineralização suportados por proteínas, a ligação de íon cálcio envolve resíduos ácidos, com uma estrutura primária ideal do tipo Asp-X-Asp (Glu), onde x é um resíduo neutro (MANN, 1989).

3. Moléculas envolvidas na interação com o cálcio em processos de mineralização apresentam como característica uma região polianiônica e uma região hidrofóbica. Enquanto a região carregada faz a ligação com o cálcio, a região hidrofóbica impede a difusão do cálcio para dar continuidade ao processo de nucleação (MANN, 1989).

Com base nessas características, recentemente foi descrito o primeiro sistema de natureza não colagênica que in vitro efetivamente mimetiza o processo de biomineralização do colágeno in vivo. Consiste de um polipeptídio contendo: a - sítios de mineralização formados por uma estrutura primária em analogia à fosfoforina, Asp-Ser $(\mathrm{P})-\mathrm{Ser}(\mathrm{P})$; b - Sítios de adesão celular RGD; c - uma região hidrofóbica para estabilização do sistema de micelas. A formação da HA é dependente da estrutura da micela, que é $\mathrm{pH}$ dependente (HARTGERINK; BENIASH; STUPP, 2001). 
O aspecto mais importante dessa estrutura é a simulação de uma cadeia polipeptídica linear contendo resíduos ácidos capazes de induzir a formação de cristais de HA orientados ao longo do eixo maior da sua estrutura. Esse sistema é o primeiro descrito na literatura capaz de induzir a formação de HA de maneira análoga à mineralização que ocorre no colágeno do Tipo I, componente orgânico majoritário do tecido ósseo (VERDE-CARVALHO; GUARINO; GONZALEZ, 2004).

Foi descrita também recentemente a mineralização de fibras de colágeno in vitro com a mesma orientação que aquela observada para o colágeno in vivo, porém, sem o auxílio de qualquer molécula de natureza biológica (GOISSIS; MAGINADOR; MARTINS, 2003; VERDE-CARVALHO; GUARINO; GONZALEZ, 2004), sugerido que a distribuição dos aminoácidos ácidos na zona do Gap é importante no processo de mineralização.

Esse modelo foi desenvolvido pelo Grupo de Biomateriais do Instituto de Química de São Carlos e está resumidamente descrito abaixo.

\subsection{Modelo para a mineralização do colágeno}

O modelo de mineralização do colágeno foi feito com base na premissa de que qualquer alteração que diminua a basicidade da interface Overlap:Gap diminui a adesão de proteínas ácidas ligadas a mineralização nesta região (Figura 21). Esse modelo de mineralização do tecido ósseo foi feito em análogia a fosfoforina, uma proteína ácida que dá inicio ao processo de biomineralização na dentina e controla o crescimento dos cristais de HA (BENIASH et al., 2000). A fosfoforina, depois do colágeno, é a proteína mais abundante na dentina e, embora haja controvérsias sobre o local exato da sua interação (DAHL; SABSAY; 
VEIS, 1998; BENIASH et al., 2000) com o colágeno, seu sítio foi definido como sendo próximo à interface Overlap:Gap.

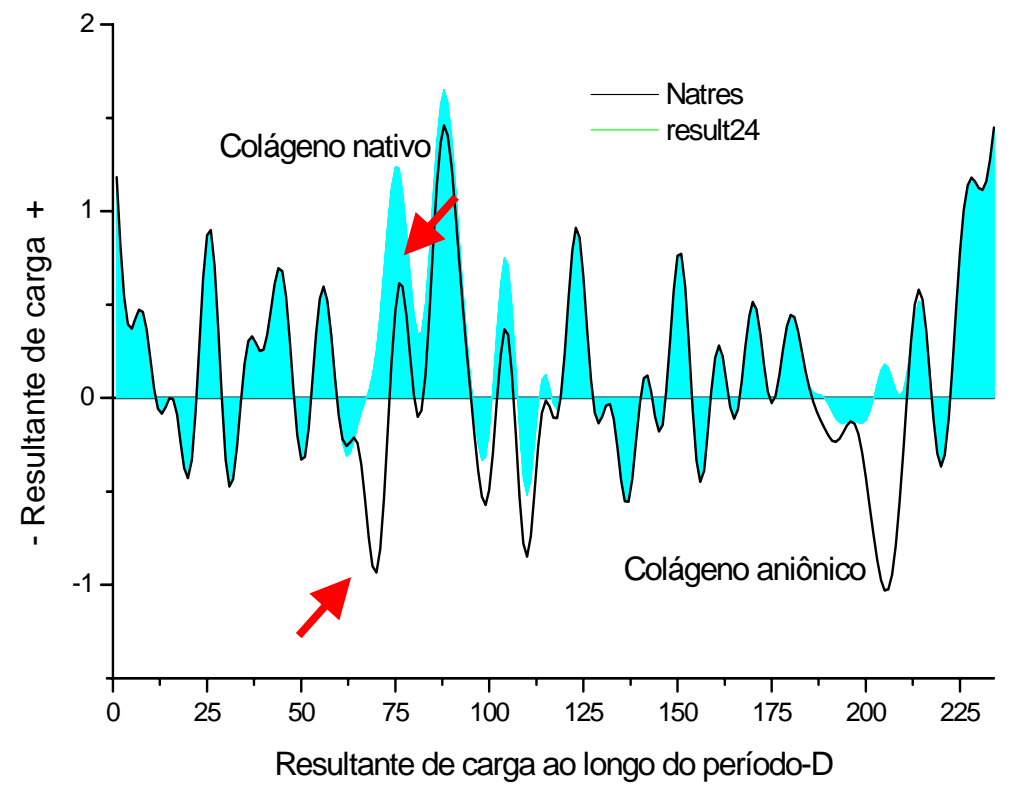

Figura 21. Resultante da distribuição de carga do período D do colágeno levando-se em consideração a distribuição dos aminoácidos ácidos e básicos. Seta: indicação da diminuição da basicidade da interface Overlap:Gap.

O progresso da mineralização é conseqüente da distribuição de Asp e Glu (Figura 22) na zona do Gap, onde estão ladeados por aminoácidos hidrofóbicos, formando uma espécie de canais para o desenvolvimento da fase mineral ao longo das cadeias alfa.

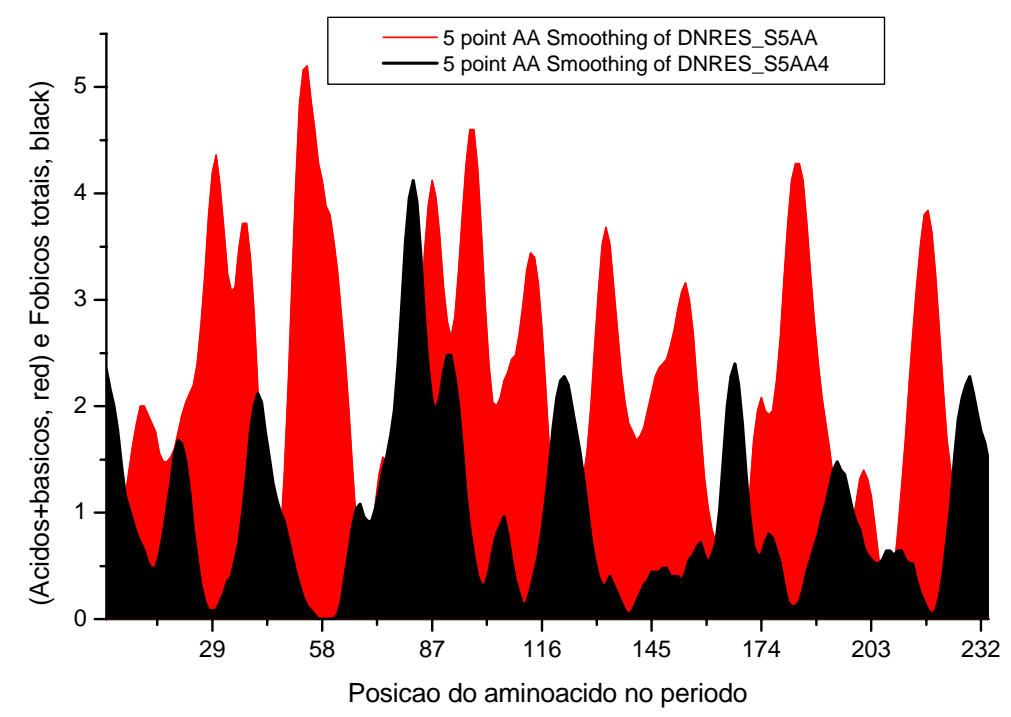

Figura 22. Distribuição de aminoácidos hidrofóbicos e a somatória de aminoácidos ácidos e básicos no período D. 
O modelo propõe as seguintes etapas (Figura 23):

- Como primeira fase da biomineralização, a ligação do cálcio nos mesmos sítios que aqueles sugeridos para o crômio (BROWN; CHEN; FEAIRHELLER, 1993; KING; BROWN; CHEN, 1996). Entretanto, tanto in vitro como in vivo, a mineralização das fibrilas do colágeno não prossegue devido à presença de uma barreira hidrofóbica presente na junção Gap:Overlap (CHAPMAN; TZAPHLIDOU; MEEK, 1990).

- Como segundo fase, essas alterações de cargas na junção Gap:Overlap (CHAPMAN; TZAPHLIDOU; MEEK, 1990) induzem a um aumento da interação eletrostática, mudança essa que seria a responsável por alteração na conformação da barreira hidrofóbica nas zonas Overlap e Gap, permitindo a migração do cálcio através da região do Gap.

In vivo, o início da mineralização ocorre na interface Gap:Overlap tanto no tecido ósseo normal quanto na dentina, nesse ultimo o sinal para mineralização é dado pela fosfoforina, uma proteína altamente aniônica que se liga ao colágeno na zona entre Gap e Overlap (WEINER; TRAUB, 1986), dando início, assim, à deposição de fosfato de cálcio. 


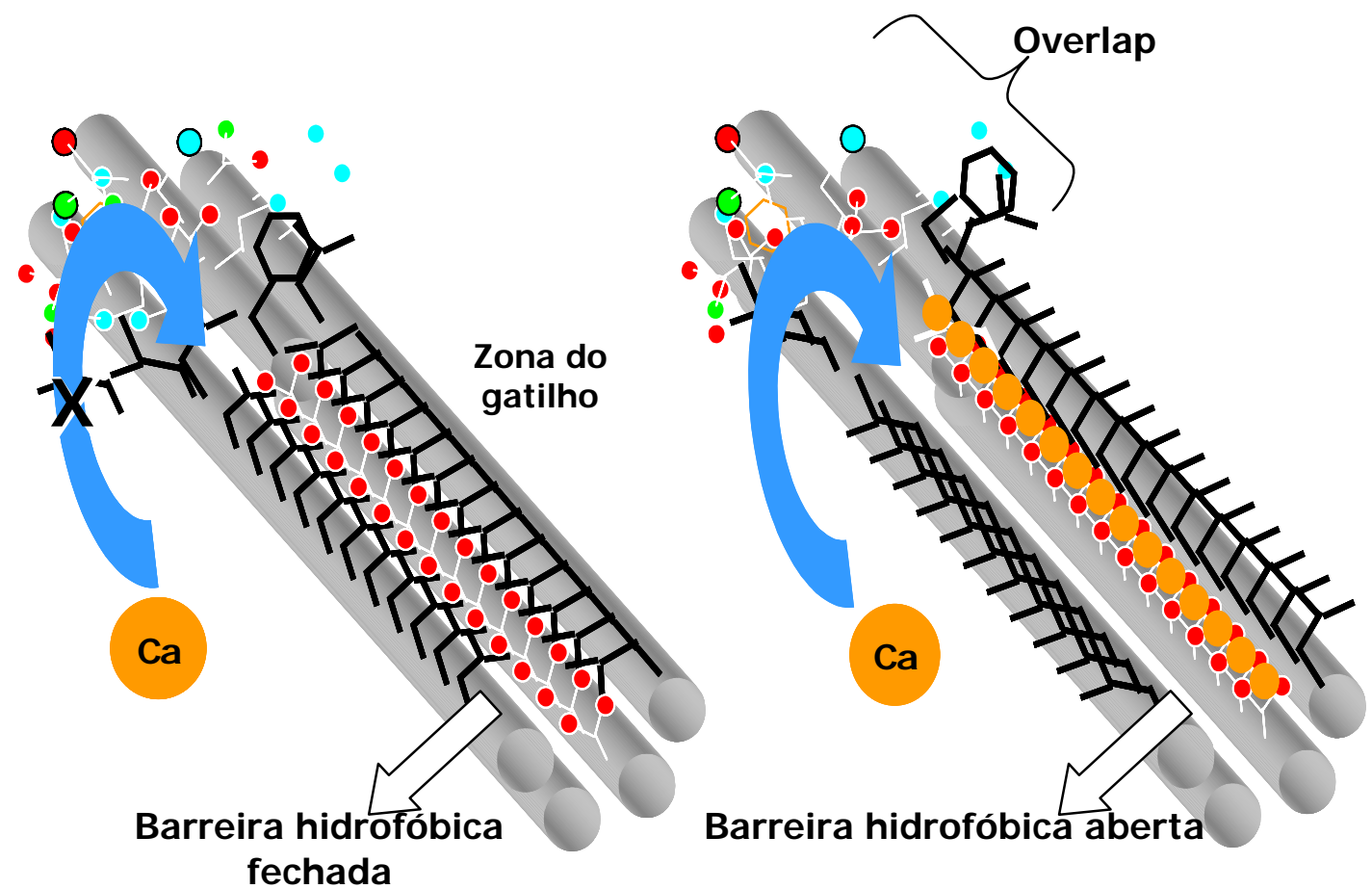

Figura 23. Modelo para mineralização in vitro de matrizes de colágeno polianiônico com $46 \pm 12$ cargas adicionais negativas, preparadas por hidrólises de cadeias laterais de resíduos de Asparagina e Glutamina presentes na estrutura colagênica.

\subsection{Características estruturais do período $\mathrm{D}$ e nas cadeias alfa do colágeno}

Com base no exposto acima, para este trabalho, o conhecimento da distribuição dos aminoácidos no período $\mathrm{D}$ e nas cadeias, principalmente os aminoácidos polares carregados e os hidrofóbicos, é extremamente importante, pois está diretamente ligado aos processos de biomineralização (WEINER; TRAUB, 1986; MAITLAND; ARSENAULT, 1991).

Em relação à sua distribuição na estrutura primária das cadeias $\alpha^{1}$ e $\alpha^{2}$ do colágeno Tipo I, os aminoácidos polares constituem cerca de $40 \%$, dos quais $11 \%$ são aminoácidos básicos, 9\% aminoácidos ácidos e o restante, 17\%, são aminoácidos hidroxilados como Ser e Treonina [Thr, doravante] e 4\% são a Asparagina [Asn, doravante] e a Glutamina [Gln, doravante]. O conteúdo de Hyl, responsável pela formação de ligações cruzadas inter e 
intramoleculares, é $0,7 \%$, e juntamente com Tirosina [Tyr, doravante], está localizado exclusivamente nas regiões dos telopeptídeos N- e C-terminais. Em relação a outras proteínas, sua estrutura primária é peculiar, pois contém 33\% de Gly, 12\% de Pro e 11\% Hyp (SILVA, 2005).

A Tabela 2 mostra a composição química do colágeno do Tipo I.

Tabela 2. Estrutura primária das cadeias $\alpha^{1}$ e $\alpha^{2}$ do colágeno Tipo I.

\begin{tabular}{|c|c|c|c|c|c|}
\hline \multirow{2}{*}{ Aminoácido. } & \multicolumn{2}{|c|}{ Cadeia } & \multirow{2}{*}{ Aminoácido } & \multicolumn{2}{|c|}{ Cadeia } \\
\hline & $\alpha_{1}$ & $\alpha_{2}$ & & $\alpha_{1}$ & $\alpha_{2}$ \\
\hline Estruturais & & & Hidrofóbicos & & \\
\hline Glicina & 345 & 346 & Leucina & 9 & 18 \\
\hline Hidroxiprolina & 114 & 99 & Isoleucina & 22 & 33 \\
\hline Prolina & 127 & 108 & Metionina & 7 & 4 \\
\hline Básicos & & & Fenilalanina & 13 & 15 \\
\hline Lisina & 34 & 21 & Tirosina & 5 & 4 \\
\hline Arginina & 53 & 56 & Valina & 17 & 34 \\
\hline Histidina & 3 & 8 & & & \\
\hline Hidroxilisina & 4 & 9 & Outros & & \\
\hline Ácidos/Amidas & & & Alanina & 124 & 111 \\
\hline Ácido aspártico & 33 & 24 & Treonina & 17 & 20 \\
\hline Asparagina & 13 & 23 & Serina & 37 & 35 \\
\hline Ácido glutâmico & 52 & 46 & & & \\
\hline Glutamina & 27 & 24 & & & \\
\hline
\end{tabular}

Esses aminoácidos estão distribuídos de forma ordenada dentro de uma unidade repetitiva que caracteriza colágenos com triplas hélices e, no caso do colágeno do Tipo I, organizam-se na forma fibrilar, cujo modelo é mostrado na Figura 24. Muito do que se sabe sobre a organização macromolecular do colágeno foi constatada pela avaliação da MET (CHAPMAN; TZAPHLIDOU; MEEK, 1990), de amostras impregnadas com sais de metais pesados, principalmente com o acetato de uranila (UA) e fosfotungstato de amônio (PTA).

O Modelo proposto por Smith e denominado de Pentafibrilar quarto alternado (CHAPMAN; TZAPHLIDOU; MEEK, 1990) é formado (Figura 24) por cinco triplas hélices de colágeno justapostas ao longo de um eixo longitudinal e deslocadas umas das outras em $1 / 4$ de seu comprimento, ou seja, cerca de 234 resíduos de aminoácidos. 


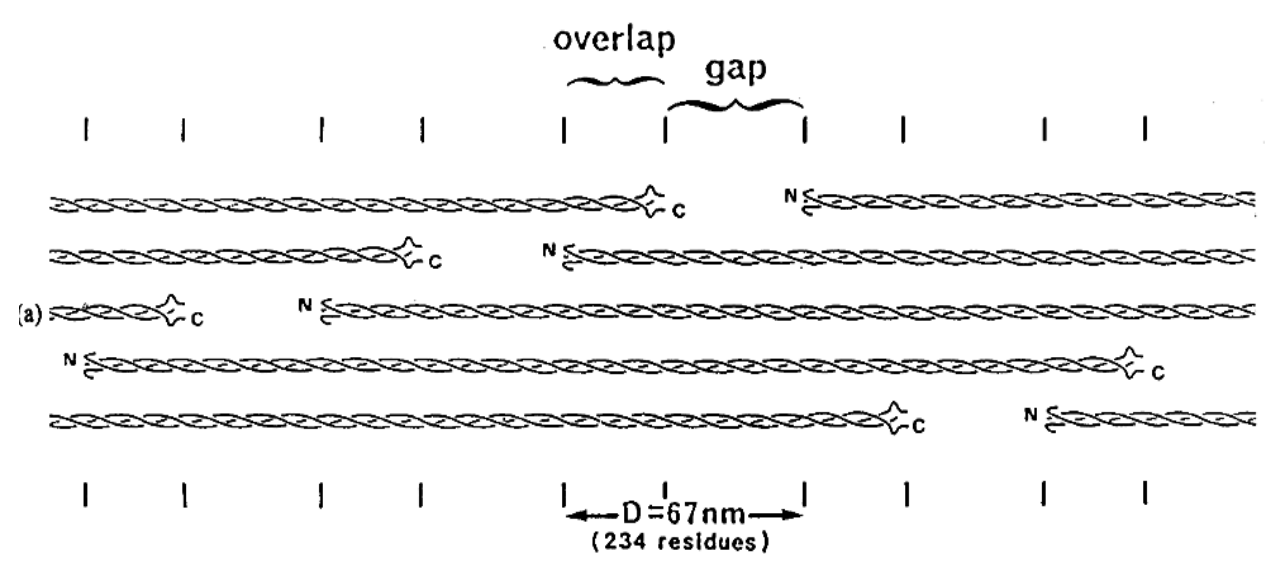

Figura 24. Modelo Pentafibrilar de Smith para a reorganização fibrilar do colágeno baseado no deslocamento da molécula de colágeno de $1 / 4$ de seu comprimento.

Respeitando o modelo descrito acima, esta foi a disposição de moléculas de colágeno que satisfazia a formação de "clusters" de aminoácidos ácidos e básicos (Figura 25) e que, ao longo do período $\mathrm{D}$, tem uma distribuição coincidente com o padrão periódico observado por MET (Figura 26). 


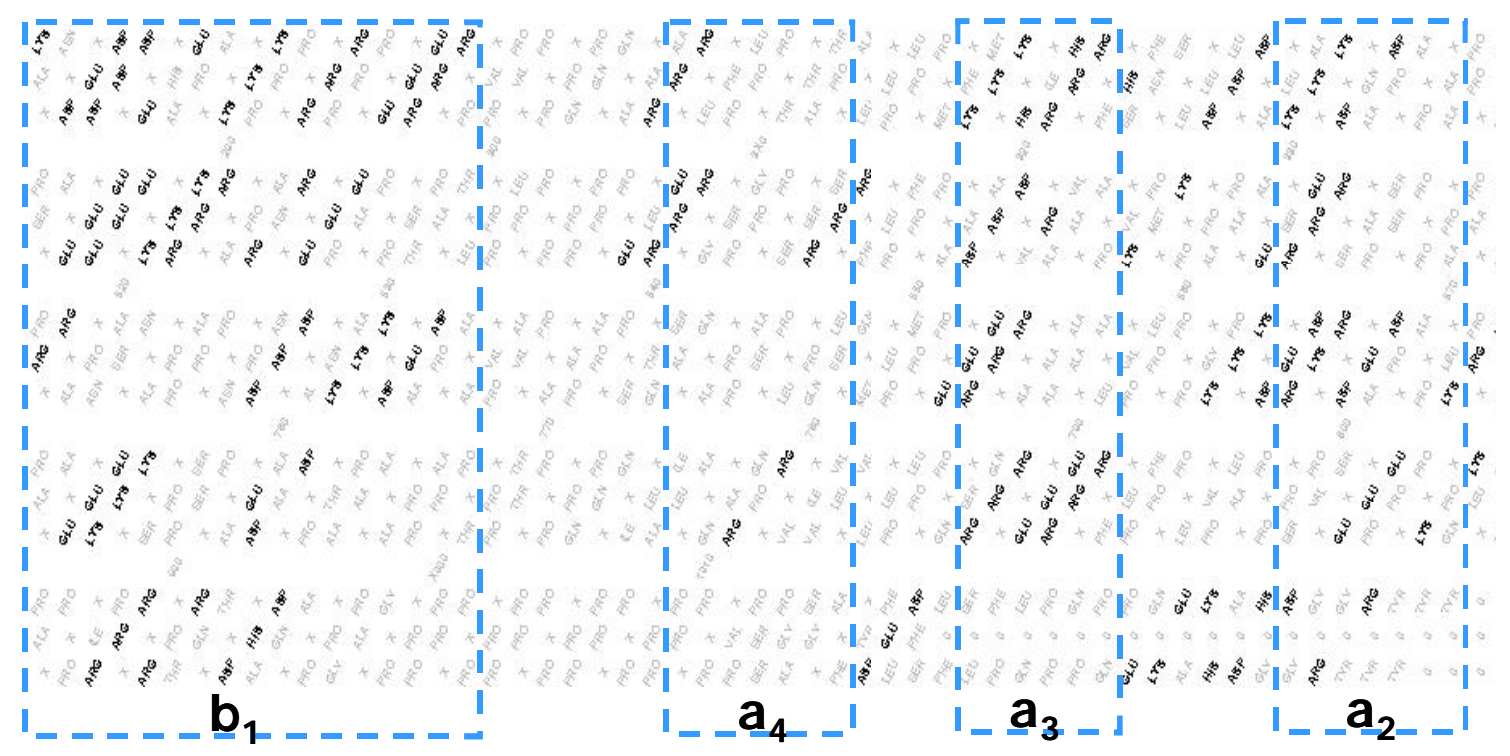

Figura 25. Esquema representativo da distribuição dos aminoácidos no período D quando cinco moléculas de colágeno são dispostas alternadamente de $1 / 4$ de seu comprimento.

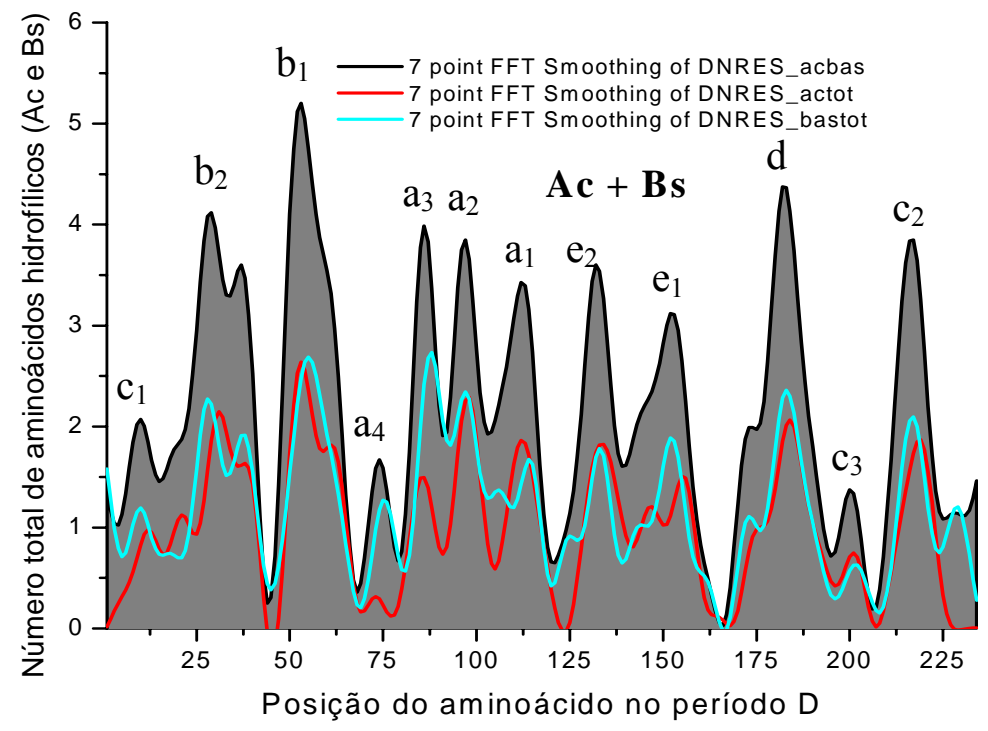

Figura 26. Distribuição da soma dos resíduos ácidos e básicos no período D da microfibrila do colágeno do Tipo I. 
4.3 Distribuição de aminoácidos básicos, ácidos e hidrofóbicos no período $\mathrm{D}$ e nas cadeias alfa

\subsubsection{Aminoácidos ácidos}

Em relação ao período D, estes aminoácidos estão distribuídos na forma de "clusters" representativos da subperiodicidade D do colágeno (Figura 27), indicando que Asp e Glu estão, no sentido transversal da fibra, na mesma região.

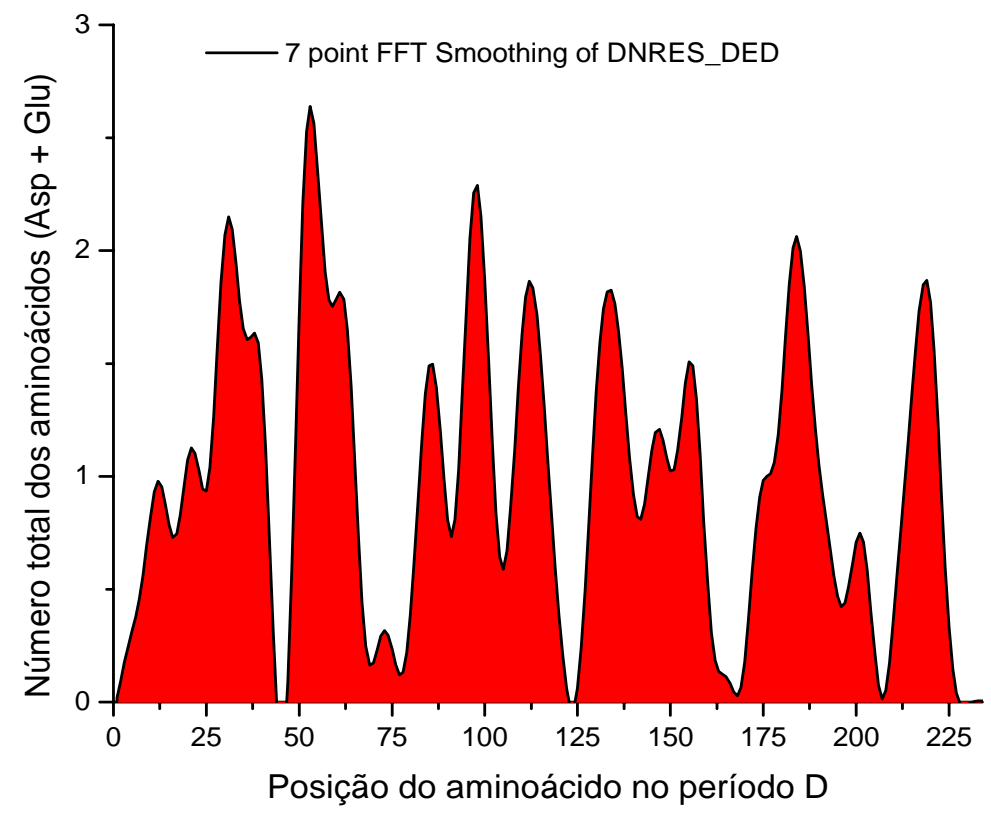

Figura 27. Distribuição no período D da microfibrila do colágeno do Tipo I da soma de resíduos de Ácido Aspártico e Ácido Glutâmico.

Observando-se esses aminoácidos isoladamente (Figura 28), pode-se perceber que eles estão distribuídos em todo o período D. 


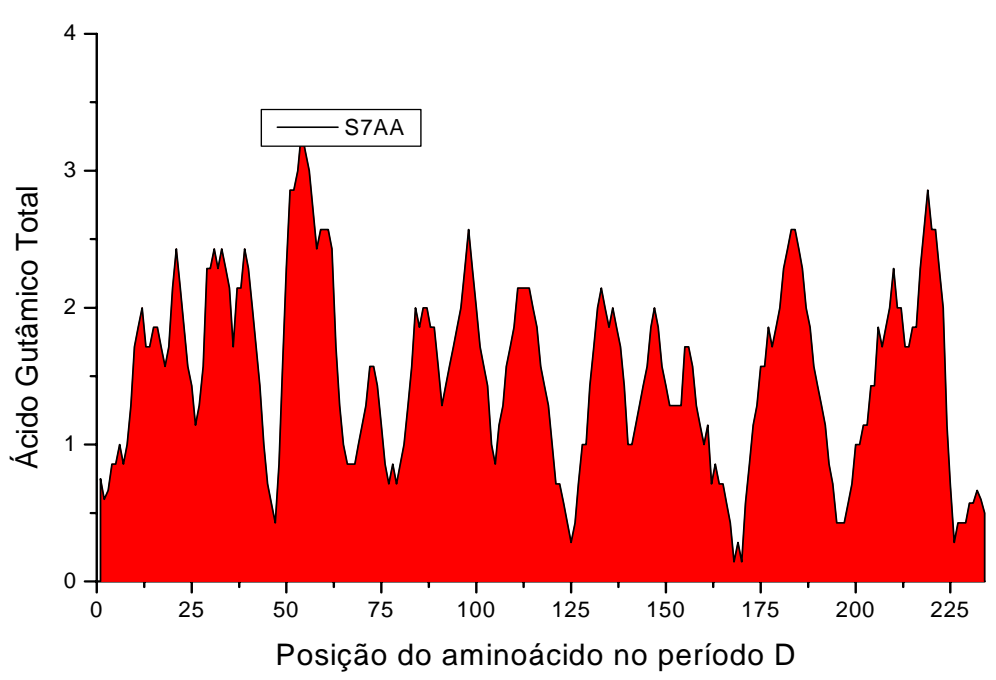

A

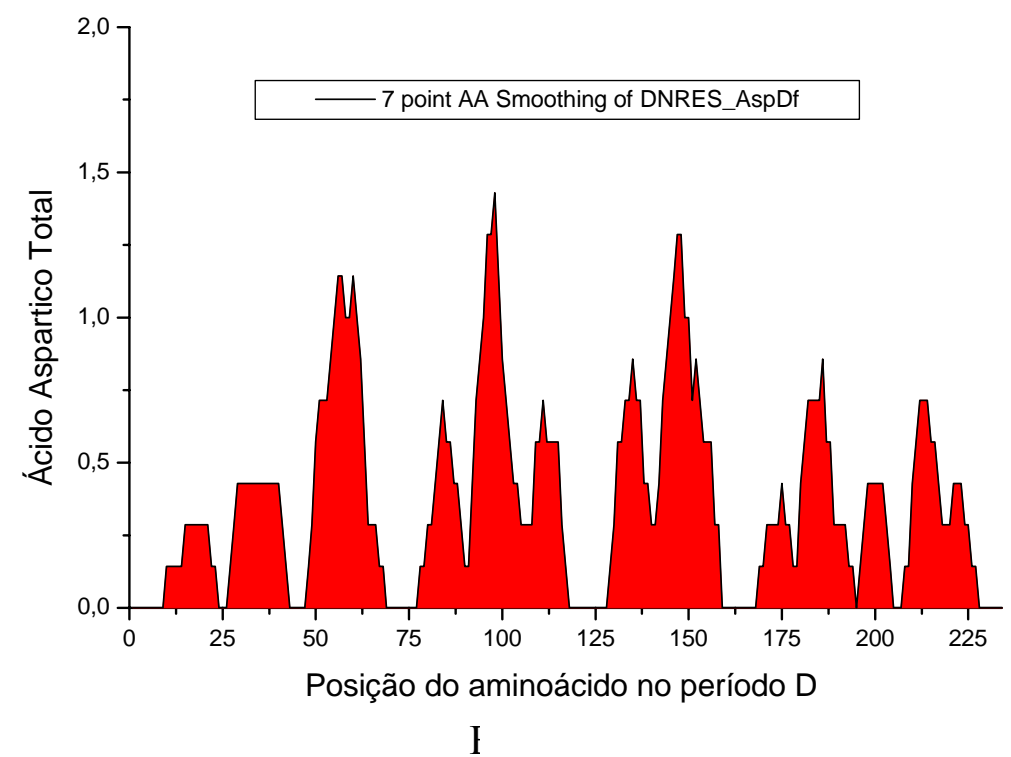

Figura 28. Distribuição do Acido Glutâmico (A) e Acido Aspártico (B) no período D.

Observando-se (Figura 29) esses aminoácidos separadamente ao longo das cadeias $\alpha$, pode-se perceber que eles não estão distribuídos ao longo da mesma tripla hélice, pois, ao passo que Glu (Figura 29a) concentra-se nas cadeias $\alpha^{1}$ e $\alpha^{1^{\prime}}$ da segunda e da quarta tripla hélice da microfibrila, o Asp está distribuído nas cadeias $\alpha^{1}$ da terceira tripla hélice da microfibrila (Figura 29b). Contudo, tanto Glu como Asp apresentam-se mais concentrados na região do Gap. 


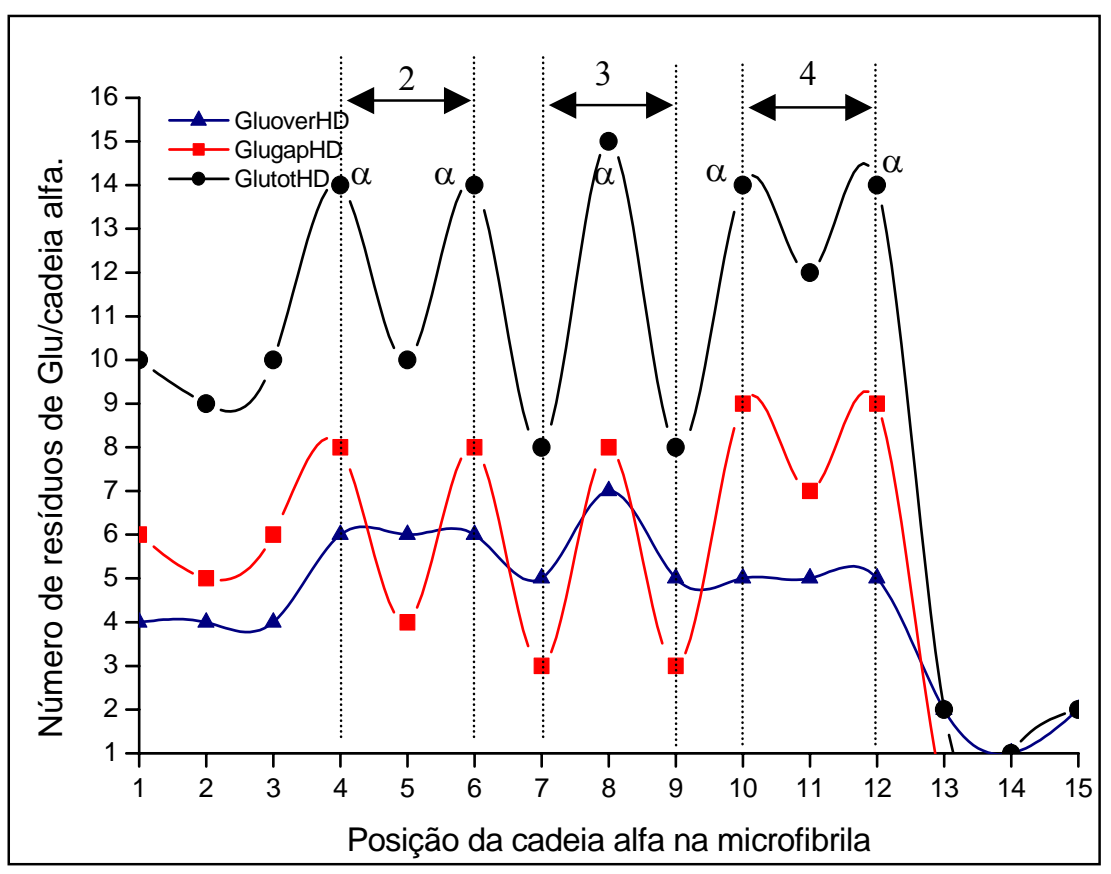

A

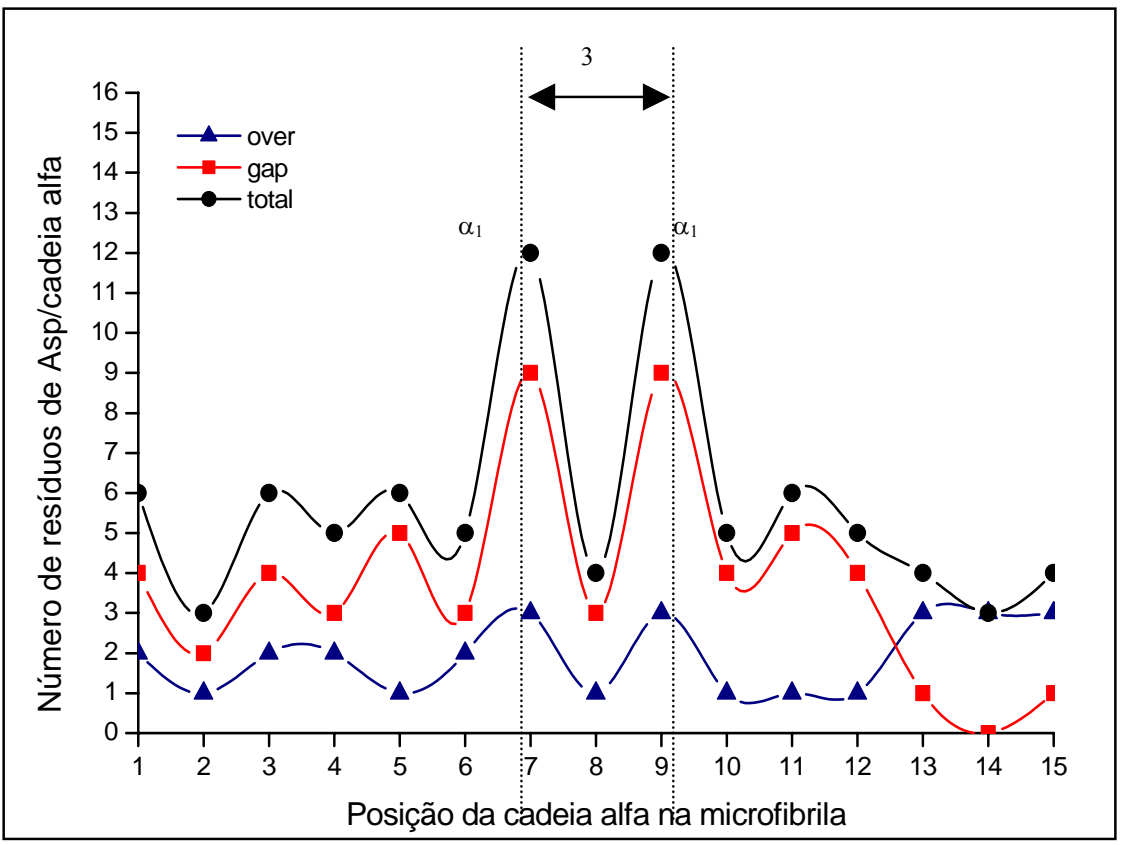

B

Figura 29. Distribuição de aminoácidos Ácido Glutâmico (A) e Ácido Aspártico (B) nas cadeias $\alpha$ que formam o período D das microfibrilas de colágeno. 


\subsection{Aminoácidos básicos}

Em relação ao período D do colágeno Tipo I, os aminoácidos básicos também estão distribuídos em todo o período D (Figura 30); observando-os isoladamente (Figura 31), percebe-se que, tanto em Arg quanto Lys, suas concentrações são maiores nas regiões do

\section{Gap.}

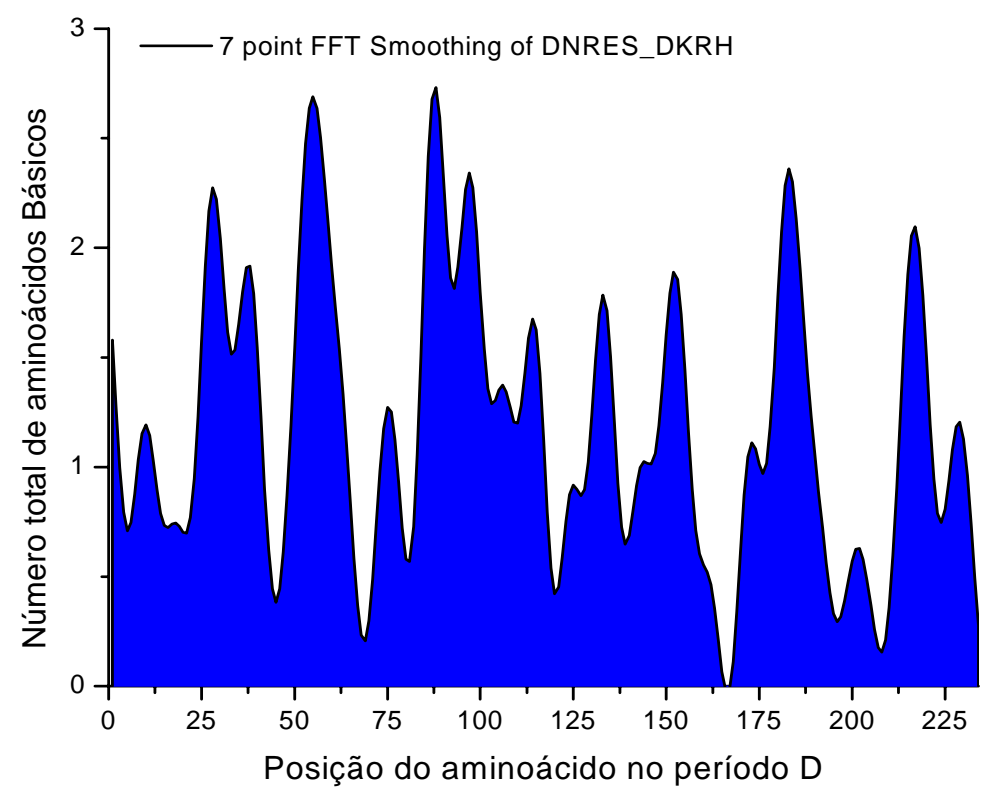

Figura 30. Distribuição da soma dos resíduos básicos no período D da microfibrila do colágeno Tipo I.

Como citado anteriormente e observado na Figura 26, esses aminoácidos encontram-se distribuídos na forma de "clusters" representativos da subperiodicidade do colágeno. 


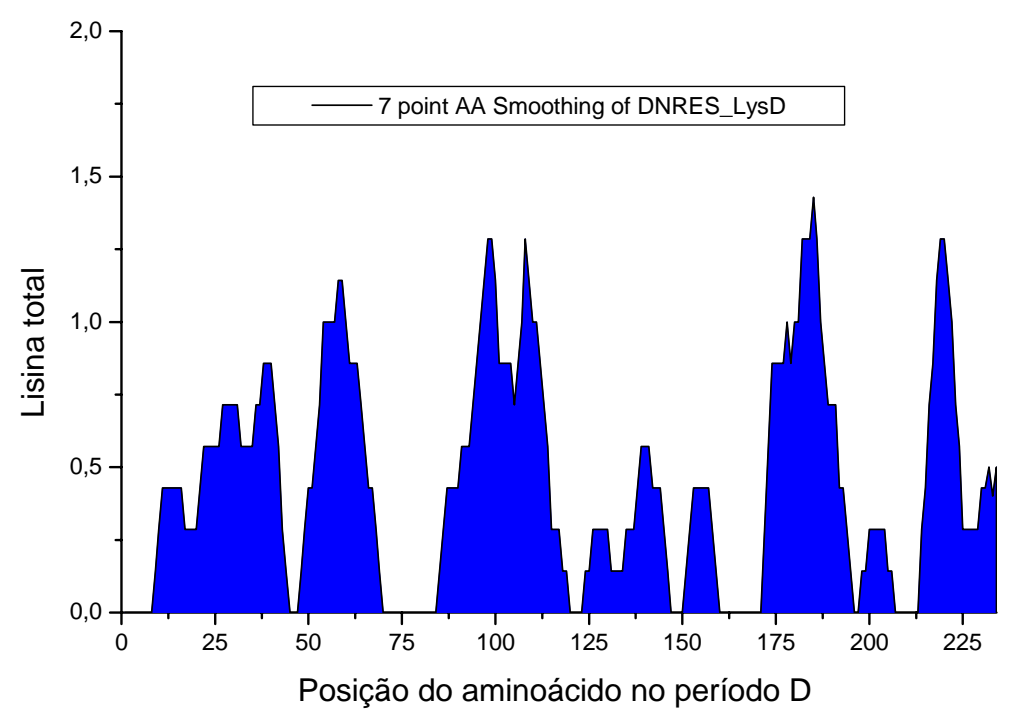

A

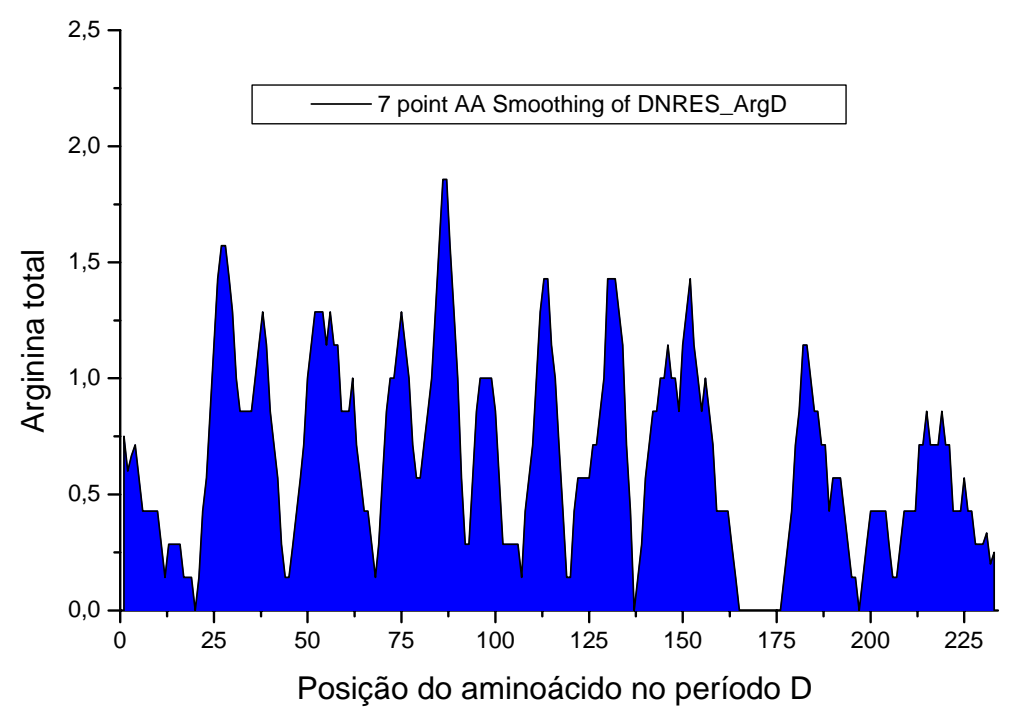

B

Figura 31. Distribuição do Lisina (A) e Arginina (B) no período D. 
Os aminoácidos básicos estão distribuídos igualmente dispostos ao longo das mesmas cadeias $\alpha$ na região do Gap (Figura 32).

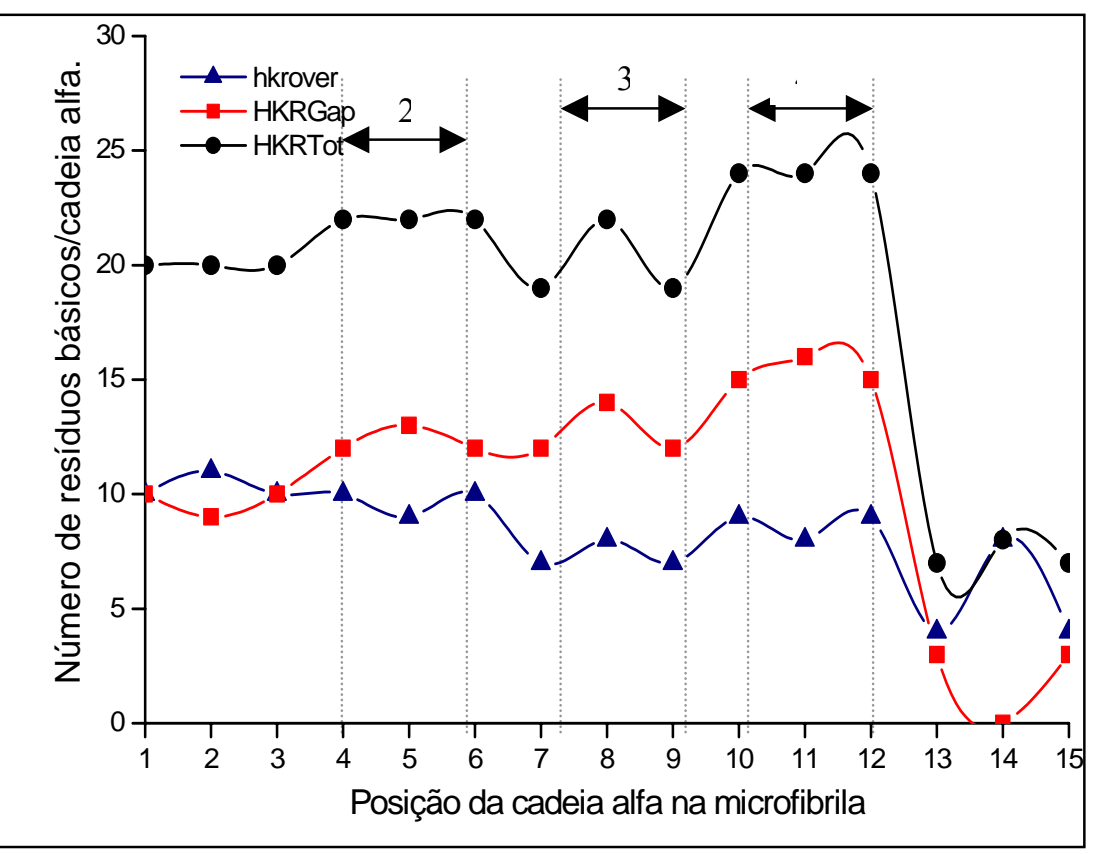

Figura 32. Distribuição de aminoácidos básicos nas cadeias $\alpha$ que formam o período $\mathrm{D}$ das microfibrilas de colágeno.

\subsubsection{Aminoácidos hidrofóbicos}

Como previamente citado na Figura 26, enfatiza-se (Figura 33) que os aminoácidos hidrofóbicos, igualmente aos ácidos e básicos, estão distribuídos formando "clusters" e ao longo da subperiodicidade do colágeno, aparecendo intercalados em relação aos aminoácidos polares carregados. 


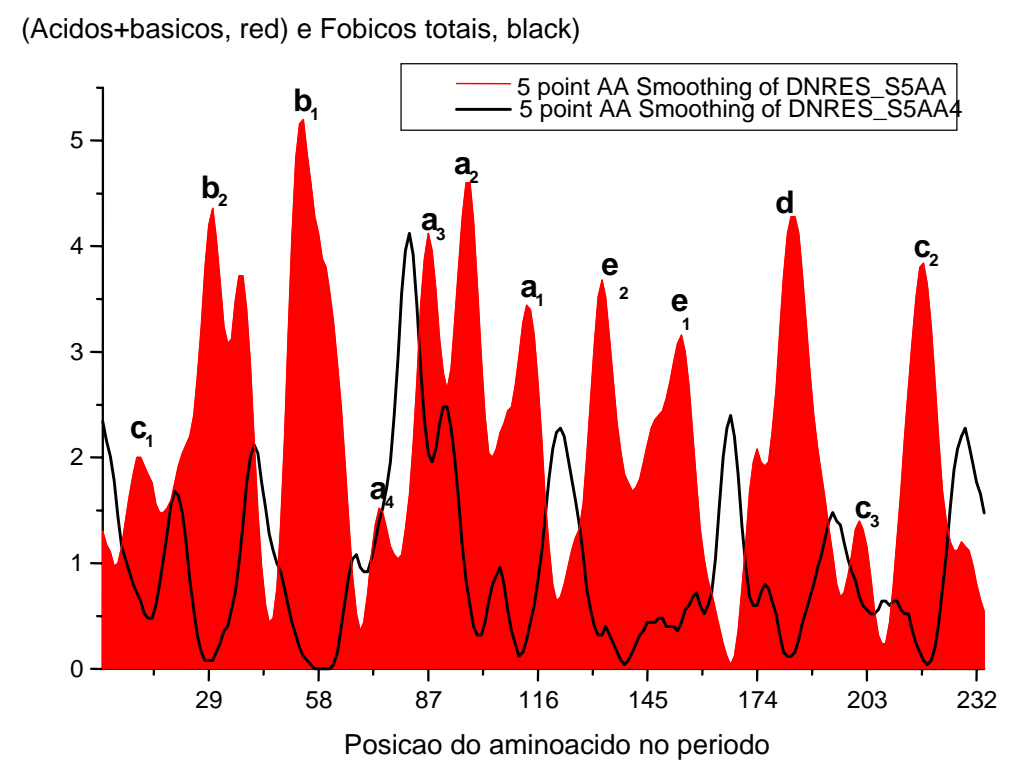

Figura 33. Distribuição no período D do colágeno do Tipo I, dos aminoácidos polares carregados e da somatória dos aminoácidos hidrofóbicos (Valina, Leucina, Isoleucina, Metionina e Fenilalanina).

Observa-se que aminoácidos hidrofóbicos ao longo da cadeia $\alpha$ se encontram distribuídos resumidamente da forma abaixo:

- Valina: cadeias $\alpha^{2}$ da primeira, terceira e quarta tripla hélice.

- Leucina: cadeias $\alpha^{2}$ da primeira, segunda e quarta tripla hélice.

- Isoleucina: cadeias $\alpha^{2}$ da segunda e da quarta tripla hélice.

- Metionina: cadeias $\alpha^{1}$ e $\alpha^{1}$ da primeira tripla hélice.

- Fenilalanina: cadeias $\alpha^{1}, \alpha^{2}$ e $\alpha^{1}$ da primeira tripla hélice.

Essa distribuição pode ser observada numa curva resultante das distribuições das somas dos aminoácidos hidrofóbicos por cadeias $\alpha$ (Figura 34). 


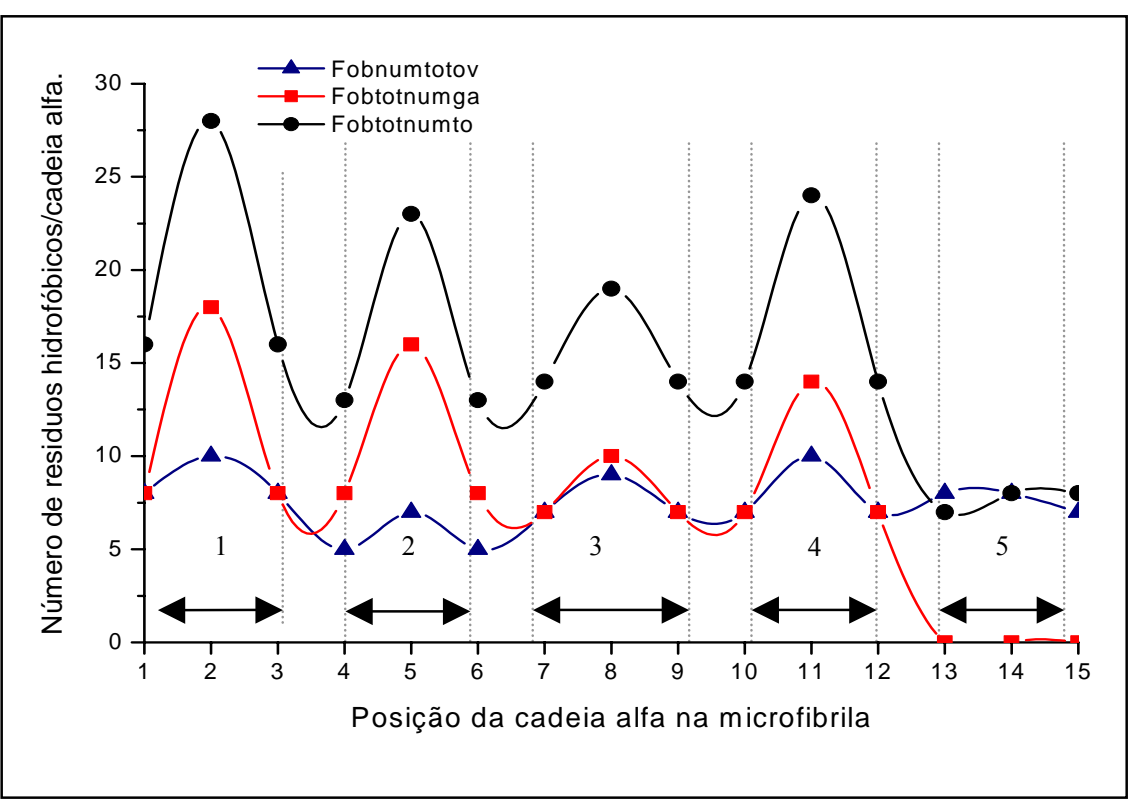

Figura 34. Distribuição da somatória dos valores numéricos relativos ao Overlap e Gap para os resíduos Valina, Leucina, Isoleucina, Metionina e Fenilalanina.

Com isso, pode-se concluir que a localização dos aminoácidos hidrofóbicos coincide também com os resultados de mineralização in vivo, onde as regiões hidrofóbicas do período D não são susceptíveis de mineralização (MAITLAND; ARSENAULT, 1991). Assim, a distribuição dos aminoácidos hidrofóbicos ao longo da cadeia alfa parece formar um vale dentro do qual estão localizados os resíduos Asp, como se pode ver na Figura 35. 


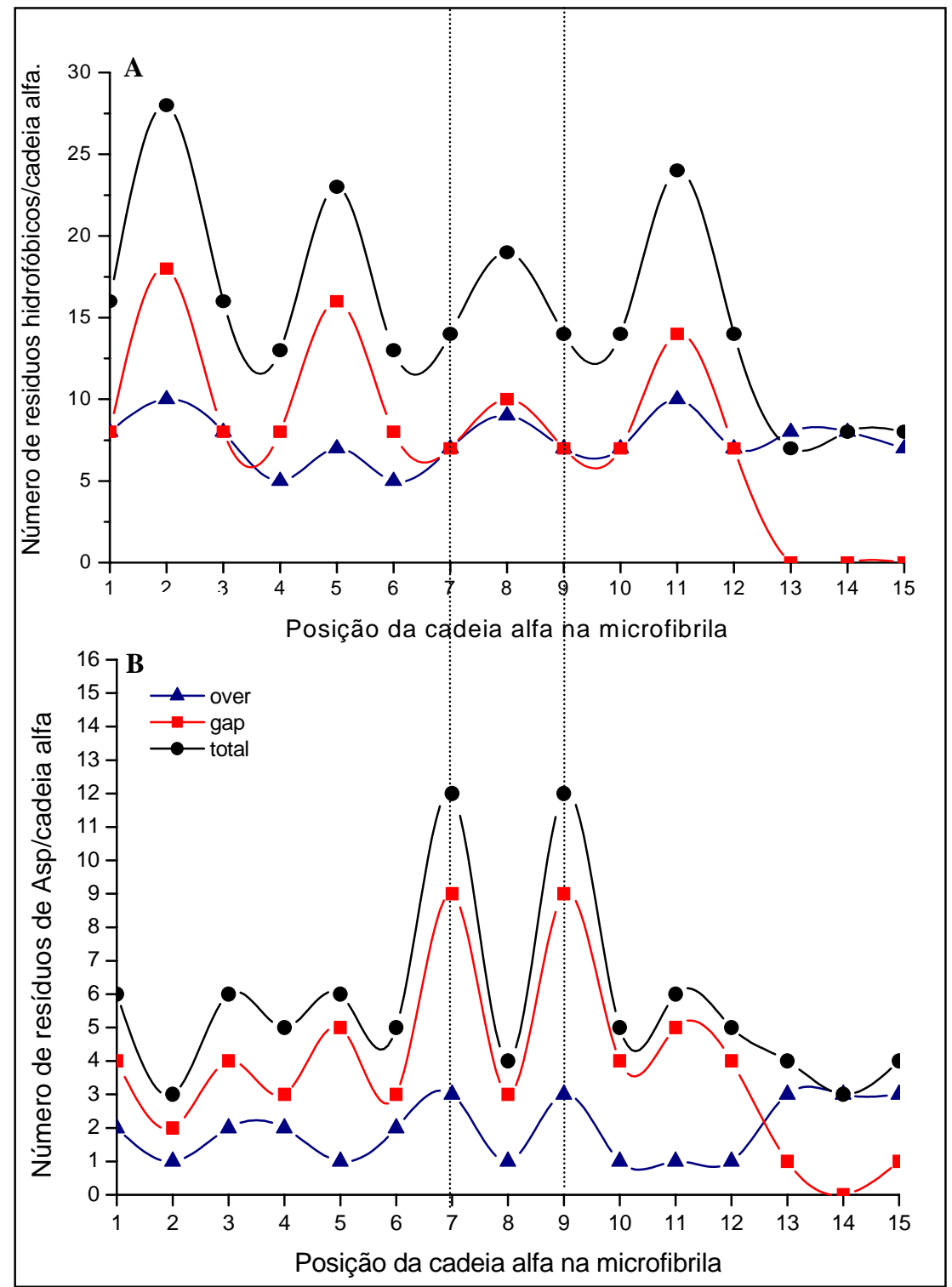

Figura 35. Comparação da distribuição da soma dos resíduos hidrofóbicos (A) e Acido Aspártico (B) nas cadeias $\alpha$ que formam o período D das microfibrilas do colágeno.

\subsection{Características estruturais do intervalo 70-110 no período $D$ do colágeno}

\section{Tipo I}

Nos gráficos acima pode-se constatar que os aminoácidos encontram-se distribuídos em todo o período D; contudo, há regiões de grande importância para o tecido ósseo por serem funcionalmente ativas. Uma delas é a região que compreende os aminoácidos da 
posição 70-110 do período D, que corresponde à interface Overlap:Gap. Essa região mostrou-se importante por ser nela que se inicia a biológico processo de mineralização do tecido ósseo (BENIASH et al., 2000).

Comparado ao modelo de Smith (CHAPMAN; TZAPHLIDOU; MEEK, 1990), o Overlap inclui os subperíodos $\mathbf{c}_{\mathbf{1}}, \mathbf{b}_{2}, \mathbf{b}_{\mathbf{1}}$ e $\mathbf{a}_{4}$, ao passo que o $\mathbf{G a p}$ inclui os subperíodos $\mathbf{a}_{3}, \mathbf{a}_{2}$, $\mathbf{a}_{1}, \mathbf{e}_{2}, \mathbf{e}_{1} \mathbf{d}, \mathbf{c}_{3}$ e $\mathbf{c}_{2}$. Esse intervalo 70-110 do colágeno Tipo I corresponde às bandas $\mathbf{a}_{4}, \mathbf{a}_{3}, \mathbf{a}_{2} \mathrm{e}$ $\mathbf{a}_{1}$ (Figura 33).

A tabela 3 mostra a distribuição de aminoácidos que estão presentes dentro da região 70-110 do período D.

Tabela 3. Distribuição dos aminoácidos ácidos, básicos, hidrofóbicos e aminas na região 70-110 do período D do colágeno tipo I, avaliados separadamente no Overlap, Gap e também na somatória total.

\begin{tabular}{cccc}
\hline AMINOÁCIDOS & OVERLAP & GAP & TOTAL \\
\hline HIDROFÓBICOS & 5 & 4 & \\
Valina & 17 & 9 & 26 \\
Leucina & 3 & 2 & 5 \\
Isoleucina & 2 & 1 & 3 \\
Metionina & 27 & 16 & 43 \\
Total & & & \\
ÁCIDOS & 2 & 15 & 17 \\
Ac. aspártico & 3 & 15 & 18 \\
Ac. glutâmico & 5 & 30 & 35 \\
Total & & & \\
AMINAS & 0 & 3 & 3 \\
Asparagina & 8 & 6 & 14 \\
Glutamina & 8 & 9 & 17 \\
Total & & & \\
BÁSICOS & 11 & 9 & 20 \\
Arginina & 0 & 2 & 2 \\
Histidina & 0 & 20 & 42 \\
Lisina & 11 & 31 & \\
Total & & & \\
\hline
\end{tabular}


As observações que se pode obter da tabela acima (Tabela 3) são:

- Do total de aminoácidos hidrofóbicos (43), há uma maior porcentagem na região do Overlap (27), ao passo que a região do Gap é menos hidrofóbica (16). Ao analisá-los separadamente, conclui-se que a Leucina [Leu, doravante] é o aminoácido de maior representação nesse grupo, correspondendo a $60,5 \%$ do total, predominando na região do Overlap, ao passo que os outros aminoácidos de menor porcentagem têm uma distribuição praticamente igual nas 2 regiões.

- Com relação aos aminoácidos ácidos, dos 35 aminoácidos totais nesse intervalo, 30 resíduos se encontram na região do Gap em comparação com a região do Overlap, que só possui 5 desses resíduos; nesse caso, tanto Asp quanto Glu apresentam-se numericamente importantes. Desse total de resíduos ácidos, aproximadamente $86 \%$ encontra-se na região do Gap, o que torna essa região do período D extremamente ácida.

- Do total de aminoácidos básicos (42), a His apresenta-se em porcentagem insignificante quando comparada à Lys e Arg que abrangem, cada uma, cerca de $47 \%$ do total desses resíduos. Contudo, aproximadamente $74 \%$ desses 3 aminoácidos posicionam-se na região do Gap e a Lys é o principal resíduo, pois se encontra 100\% localizada nessa região.

- Em relação às aminas, pode-se dizer que não há diferença significativa entre as duas regiões e, desses resíduos, a Gln encontra-se em maior quantidade nas 2 regiões.

Dessa forma, observando-se esses números, podemos dizer a região do Overlap é de maior hidrofobicidade, ao passo que a região do Gap apresenta a maior porcentagem de aminoácidos carregados. No processo de "ageing", como já dito anteriormente, altera-se os aminoácidos Asp, Arg e Lys e, dessa forma, a região do Gap é a que mais se altera com a deterioração desses aminoácidos, pois Lys distribui-se 100\% nessa região, ao passo que Asp encontra-se com $88 \%$ e a Arg com 45\%. Essa região alterada terá várias repercussões no 
tecido ósseo e a modificação desses resíduos levará à modificação de carga nessa região e, com isso, o processo de biomineralização encontra-se alterado.

Para melhor compreender esse processo e relacioná-lo à alteração do intervalo 70-110 do período $\mathrm{D}$, podemos analisar separadamente os grupos de aminoácidos nessa região:

A. Hidrofóbicos: Não há alteração desses aminoácidos nessa região; assim, não se altera a barreira hidrofóbica na região do Overlap que funciona como canal para o desenvolvimento da fase mineral ao longo das cadeias alfa durante a mineralização (MANN, 1989).

B. Básicos: Basicamente a Arg e Lys são os aminoácidos que têm maior repercussão sobre essa região, pois, quando modificados pelo processo de "ageing", irão alterar a polaridade que, deixando de ser extremamente positiva, não permitindo a interação da fosfoforina, proteína ácida relacionada ao início da mineralização da dentina. Os níveis de Arg e Lys são geralmente altos em proteínas, apesar de nem todos os resíduos desses aminoácidos sofrerem glicação (BAILEY; PAUL; KNOTT, 1998). Há evidências de que a glicação ocorre na região do Gap, a qual deve ser mais suscetível à glicose do que na região do Overlap (WESS et al., 1993).

Portanto, levando-se em consideração as alterações da matriz colagênica provocadas pelo "ageing" e que incluem:

1- Alteração da Arg que participa de seqüências do Arg-Gly-Asp (RGD), sítios de reconhecimento de 2 integrinas da matiz como $\alpha^{1} \beta^{1}$ e $\alpha^{2} \beta^{1}$ (BAILEY, 2001), afetando dramaticamente a interação do colágeno com células após a glicação (PAUL; BAILEY, 1999). Esse é o caso de osteoblasto, o qual altera a remodelagem do tecido ósseo e, por si só, 
seria um motivo importante o suficiente para acreditar que o colágeno modificado poderia não se remodelar normalmente, causando várias desordens no tecido ósseo pela alteração na formação óssea, da síntese da matriz e do metabolismo ósseo (WEINSTEIN; BUCKWALTER, 2000). O mesmo raciocínio é aplicado aos resíduos de Asp.

2- Alteração da Lys pelo processo de "ageing", alterando a formação de ligações cruzadas na região dos telopeptídeos N- e C-terminal e da região helicoidal (BAILEY; PAUL; KNOTT, 1998; PAUL; BAILEY, 1999; BAILEY, 2001) retardando o processo de fibrilogênise e ocasionando o aumento da fragilidade nesse tecido (BAILEY; KNOTT, 1999) que, com menor diâmetro (KNOTT et al., 1995), dificultam a deposição dos cristais de HA e, com isso, a mineralização.

Este trabalho propõe que as reações de "ageing" têm implicações na osteoporose e estão ligadas diretamente ao processo intrínseco da biomineralização e que dependem, essencialmente, da integridade da estrutura da matriz colagênica, ocorrendo em dois níveis distintos:

I - O primeiro, ligado diretamente ao processo de sinalização para o início da mineralização para a formação dos depósitos de HA envolvendo a interface Overlap:Gap. Neste caso, as alterações nas cadeias laterais de Arg e Lys nesta região não mais permitiriam as alterações necessárias para o início da deposição de cristais de HA na zona do Gap, reconhecidamente a zona onde há o início da biomineralização. Alterações da carga nesta região impediriam a interação com moléculas sinalizadoras, como é o caso da fosfoforina na dentina. A resultante do "ageing" nesta região seria essencialmente uma diminuição da basicidade devido à formação de bases mais fracas. Não fica excluída a possibilidade de alterações conformacionais sugerindo que a zona de pré-mineralização de matrizes de 
colágeno é altamente dinâmica sofrendo modificações. Mecanismo similar foi proposto para o controle do crescimento de cristais de oxalato de cálcio sobre a proteína $\mathbf{G}$, caracterizados pela presença de 10 grupos carboxílicos quando comparado com um mutante quando 4 carboxilas são substituídas por grupos carboxamidas (BROWN; CHEN; FEAIRHELLER, 1993). Esta alteração inibe a formação do oxalato de cálcio e o efeito é atribuído a mudanças no potencial eletrostático de superfície da proteína associado a alterações das características hidrofóbicas superficiais da proteína $\mathbf{G}$.

II- Alterações de resíduos de Asp e Glu na zona do Gap, que como sugerido pelo modelo serviriam de sítios de mineralização ou seja deposição da HA. Este aspecto é relevante principalmente se levarmos em consideração que:

a. O crescimento dos cristais de HA na zona Gap ocorre ao longo do eixo longitudinal da fibrila de colágeno (WEINER; TRAUB, 1986; BENIASH et al., 2000), pressupondo um ordenamento de sítios de interação na mesma direção.

b. O processo de biomineralização do colágeno deve envolver a participação de Asp e Glu estrategicamente dispostos na estrutura primária das cadeias $\alpha$, principalmente na zona do Gap, onde tem início o processo de biomineralização (WEINER; TRAUB, 1986; MAITLAND; ARSENAULT, 1991; BENIASH et al., 2000). Em outros sistemas de biomineralização suportados por proteínas, a ligação de íon cálcio envolve resíduos ácidos, com uma estrutura primária ideal do tipo Asp-X-Asp (Glu), onde x é um resíduo neutro (MANN, 1989).

c. Moléculas envolvidas na interação com o cálcio em processos de mineralização apresentam como característica uma região polianiônica e uma região hidrofóbica. Enquanto a região carregada faz a ligação com o cálcio, a região hidrofóbica impede a difusão do cálcio para dar continuidade ao processo de nucleação (MANN, 1989). 


\section{CONCLUSÃO}

A alteração do colágeno Tipo I pelo processo de "ageing" leva a mudança na topografia dos aminoácidos, principalmente Arg e Lys. Essa modificação localizada especialmente no intervalo 70-110 do período D, região correspondente à interface Overlap:Gap, gera uma diminuição na basicidade dessa região, alterando a interação de células ligadas a manutenção do tecido ósseo e a sua mineralização, também afetando o processo de adesão celular pois altera a seqüência RGD (Arg-Gly- Asp). No caso da dentina, essas alterações interferem na sua interação com a fosfoforina, repercutindo no gatilho para mineralização. Acredita-se que de forma análoga, ocorra alteração na mineralização do tecido ósseo, como conseqüência do "ageing".

Dessa forma, no estudo da osteoporose, devem-se considerar as alterações da estrutura do colágeno provocadas pelo processo de "ageing", pois levam a uma matriz modificada, o que altera funcionalmente do tecido ósseo. 


\section{REFERÊNCIAS BIBLIOGRÁFICAS}

ALBERTS, B. et al.(1994). Molecular biology of the cell. New York: Garland. p.971-995.

BAGNOLI, V. R. et al. (1998). Síndrome do climatério, osteoporose: como diagnosticar e tratar. Revista Brasileira de Medicina, São Paulo, v.55, n.12, Dez. Disponível em:< http: // www.cibersaude.com.br./ revistas.asp?fase=r003\&id-materia=1529>. Acesso em 24 jun.2002.

BAILEY, A.J. (2001). Molecular mechanisms of ageing in connective tissues. Mechanisms of Ageing and Development, Amsterdam, v.122, n.7, p.735-755, May.

(2002). Changes in bone collagen with age and disease. Journal of Musculoskeletal and Neuronal Interactions, Nafplion, v 2. , n.6, p.529-531, Aug.

BAILEY, A.; KNOTT, L. (1999). Molecular changes in bone collagen in osteoporosis and osteoarthritis in the elderly. Experimental Gerontology, New York, v.34, n.3, p.337-351, June.

BAILEY, A.J.; PAUL, R.G.; KNOTT, L. (1998). Mechanisms of maturation and ageing of collagen. Mechanisms of Ageing and Development, Amsterdam, v.106, n.1/2, p.1-56, Dec.

BARENBERG, S.A.; FILISKO, F.E.; GEIL,P.H. (1978). Ultrastrutural deformation of collagen. Connective Tissue Research, Philadelphia, v.6, n.1, p.25-35.

BASSET, C.A. (1965). Electrical effects in bone. Scientific America, New York, v.213, n.4, p.18-25, Oct.

BENIASH, E. et al. (2000). Transmission electron microscope study using vitrified ice sections of predentin: structural changes in the dentin collagenous matrix prior to mineralization. Journal of Structural Biology, Duluth, v.132, n.3, p.212-225, Dec.

BERDAL, A. et al. (1991). The cellular and extracellular distribution of osteocalcin and phosphoprotein in teeth of vitamin D-deficient rats. The Journal of Biological Buccale, Paris, v.19, p.45-53. 
BERTHET-COLOMINAS, C.; MILLER, A.; WHITE, S.W. (1979). Structural study of the calcifying collagen in turkey leg tendons. Journal of Molecular Biology, London, v.134, n.1, p.431-445, Oct.

BROWN, E.M.; CHEN, J.M.; FEAIRHELLER, S.H.J. (1993). Predict interactions of ionizable side chains in a fragment of the three-dimensional energy-minimized model for calf skin type I collagen microfibril. Journal of the American Leather Chemists Association, Lubbock, v.88, n.1, p.02-11, Jan.

BURR, D.B. (2002). Bone material properties and mineral matrix contributions to fracture risk or age in women and men. Journal Musculoskeletal Neuronal Interactions, Nafplion, v. 2, n.3 , p.201-204, Jul.

CALVERT, P.D. (1994). Biomimetic mineralization: processes and prospects. Materials Science and Engineering, Amsterdam, p.69-74.

CHAPMAN, J.A.; TZAPHLIDOU, M.; MEEK, K.M. (1990). The collagen fibril: a model system for studing the staining and fixation of a protein. Electron Microscope Review, Oxford, v.3, n.1, p.143-182.

CHIQUET, M. (1999). Regulation of extracellular matrix gene expression by mechanical stress. Matrix Biology, Stuttgart, v.18, n.5, p.417-426, Oct.

COOPER, C.; CAMPION, G.; MELTON III, L.J. (1992). Hip fracture in the elderly: a world -wide projection. Osteoporosis International, Guildford, v.2, n.6, p.285-289, Nov.

CUMMINGS, S.R. et al. (1985). Epidemiology of osteoporosis and osteoporotic fractures. Epidemiologic Reviews, Baltimore, v.7, p.178-208.

DAHL, T.; SABSAY, B.; VEIS, A. (1998). Type I collagen-phosphophoryn interactions: specificity of the monomer-monomer binding. Journal of Structural Biology, Duluth, v.123, n.2, p.162-168, Oct.

DATABASE of human type I and type III collagen mutations. (2003). Disponível em:<http://www.le.ac.uk/genetics/collagen>. Acesso em: 18 Sept. 2003.

DATASUS (2005). Banco de dados (on-line). Disponível em:<http://www.datasus.gov.br>. Acesso em: 1 dez. 2005. 
DEUEL, T.F. (1997). Introduction in tissue engineering. In: LANZA, R.P.; LANGER, R.; CHICK, W.L. Principles of tissue engineering. San Diego: Academic Press. p.133-149.

DI LULLO, G.A. et al. (2002). Mapping the ligand binding sites and disease-associated mutations on the most abundant protein in the human, type I collagen. Journal of Biology Chemistry, Baltimore, v.277, n.6, p.4223-4231, Feb.

DOUGLAS, R. et al. (2000). Decorin binds near the C terminus of type I collagen. Journal of Biological Chemistry, Baltimore, v.275, n.29, p.21801-21804, July.

FRANCIS, R.M.; SUTCLIFFE, A.M.; SCANE, A.C. (1998). Pathogenesis of osteoporosis. In: STEVENSON, J.C; LINDSAY, R. Osteoporosis. London: Chapman \& Hall Medical.

FREY, P. et al. (1997). A new injectable cross-linked collagen for the endoscopic treatment of vesicouretal reflux - a double blind study evaluating its efficiency in children. Journal of Urology, Baltimore, v.158, n.4, p.1210-1213.

FROST, H.M. (1997). Defining osteopenia and osteoporosis: another view (with insights from a new paradigm). Bone, Elmsford, v.20, n.5, p-385-391, May.

FROST, H.M.; JEE, W.S.S. (1992). On the rat model of human osteopenias and osteoporosis. Bone and Mineral, Amsterdam, v.18, p.227-236.

GILSANZ, V. (1998). Phenotype and genotype of osteoporosis. Trends in Endocrimology and Metabolism, New York, v.9, n.5, p.184-190, July.

GOISSIS, G.; MAGINADOR, S.V.S.; MARTINS, V.C.A. (2003). Biomimetic mineralization of charged collagen matrices: in vitro and in vivo study. Artificial Organs, Cleveland, v.27, n.5, p.425-431, May.

GOLDBERG, A.M.; SMITH, A.J. (2004). Cells and extracellular matrices of dentin and pulp: a biological basis for repair and tissue engineering. Crittical Review in Oral Biology and Medicine, Boca Raton, v.15, n.1, p.13-27, Jan.

GUYTON, A.C. (1991). Fisiologia humana e mecanismos das doenças. 5.ed. Rio de Janeiro: Guanabara Koogan. v.1, p.574.

HARTGERINK, J.D.; BENIASH, E.; STUPP, S.I. (2001). Self-assembly and mineralization of peptide-amphiphile nanofibers. Science, Washington, v.294, n.5547, p.1684-1688, Nov. 
HAY, E. (1992). Cell biology of extracellular matrix. $2^{\text {nd }}$ ed. New York: Plenum Press.

HE, G. et al. (2003). Nucleation of apatite crystals in vitro by self-assembled dentin matrix protein 1. Nature Materials, London, v.2, n.8, p.552-558, Aug.

HEANEY, R.P. (1987). Qualitative factors in osteoporotic fratures: the state of the question. Osteoporosis, Sheffield, p.281-287.

HEINO, J. (2000). The collagen receptor integrins have distinct ligand recognition and signaling functions. Matrix Biology, Stuttgart, v.19, n.4, p.319-323, Aug.

HOSHI, K. et al. (1999). The primary calcification in bones follows removal of decorin and fusion of collagen fibrils. Journal of Bone and Mineral Research, New York, v.14, n.2, p.273-280, Feb.

HUMAN protein reference database. (2003). Collagen, type I, alpha 2, interactions. Disponível em:<http://www.hprd.org/>. Acesso em: 18 Spet. 2003.

INSTITUTO BRASILEIRO DE GEOGRAFIA E ESTATÍSTICA (2006). Censo demográfico 2006. Disponível em:<http//www.ibge.gov.br/>. Acesso em: 1 fev. 2006.

JOHNSTON, C.C.; SLEMENDA , C.M. (1985). Pathogenesis of vascularized and nonvascularized autografts. Clinical Orthopaedics, Philadelphia, n.197, p.32-43.

JUNQUEIRA, L.C.; CARNEIRO, J. (1990). Histologia básica. 7.ed. Rio de Janeiro: Guanabara Koogan. p.101-107.

KAPLAN, F.S. et al. (1996). Form and function of bone. In: SHELDON, R.S. Orthopaedic basic science. Rosemont: American Academy of Orthopaedic Surgeons. Cap.4, p.127-184.

KING, G.; BROWN, E.M.; CHEN, J.M. (1996). Use of computer-generated models in studies of modified collagen. Journal of the American Leather Chemical Association, Lubbock, v.91, n.6, p.161-170, June.

KNOTT, L. et al. (1995). Biochemical changes in the collagenous matrix of osteoporotic avian bone. Biochemical Journal, Calchester, v.310, pt.3, p.1045-1051, Sept. 
LANGER, R. et al. (1990). Future directions in biomaterials. Biomaterials, Guildford, v.11, n.9, p.738-745, Nov.

LANGER, R.; VACANTI, J.P. (1993). Tissue engineering. Science, Washington, v.260, n.5110, p.920-925, May.

LANZA, R.P.; LANGER, R.; CHICK, W.L. Principles of tissue engineering. San Diego: Academic Press. p.23-46.

LAUFENBURGER, D.A.; LINDERMAN, J.L. (1993). Receptors: models for binding, tracking, and signaling. New York: Oxford University Press.

LERNER, U.F. (2000). Osteoclast formation and resorption. Matrix Biology, Stuttgart, v.19, n.2, p.107-120, May.

MAITLAND, E.M.; ARSENAULT, L. (1991). A correlation between the distribution of biological apatite and aminoacids sequence of type I collagen. Calcified Tissue International, New York, v.48, n.5, p.341-352, May.

MANN, S. (1989). Crystallochemical strategies in biomineralization. In: MANN, S.; WEBB, J.; WILLIANS, R.J.P. Biomineralization. Weinheim: VCH. p.1-39.

MARCUS, R.; FELDMAN, D.; KELSEY, J. (1996). Osteoporosis. San Diego: Academic Press.

MYLLYHARJU, J.; KIVIRIKKO, K.I. (2004). Collagens and their mutations: from man to drosophila and caenorhabditis elegans. Trends in Genetics, Cambridge, v.20, n.1, p.33-43, Jan.

NETO, J.F.M.; FERNANDES, C.M. (2001) Mecanismos de desenvolvimento da osteoporose e suas implicações clínico-terapeuticas em Projeto Osteoporose 2001, Presente e Futuro da Osteoporose: aspectos clínicos e terapêuticos. Sociedade Brasileira de Osteoporose (SOBRAC) cap.2, p1-30.

NORDIN, B.E.C. (1987). The definition and diagnosis of osteoporosis. Calcified Tissue International, New York, v.40, n.2, p.54-57, Feb.

NOTELOVITZ, M. (2001). Osteoporose: prevenção, diagnóstico e conduta. 3.ed. Rio de Janeiro: Publicações Científicas. 
PAIVA L.C. et al. (2003) Prevalência de Osteoporose em mulheres na Pós-menopausa e Associação com Fatores Clínicos e Reprodutivos. Revista Brasileira de Ginecologia e Obstetrícia, v.25, n.7, p.507-512, Agosto.

PAUL, G.; BAILEY, A.J. (1999). The effect of advanced glycation end-product formation upon cell-matrix interactions. International Journal of Biochemistry \& Cell Biology, New York, v.31, n.6, p.653-660, June.

POLLACK, S.R. (1984). Bioelectrical properties of bone. In: BRIGTHON, C.T. Orthopedic Clinics of North America, Pennsylvania, Daunders Company, v.15, p.3-14.

REISER, K.M.; AMIGABLE, M.A.; LAST, J.A. (1992). Nonenzymatic glycation of type I collagen. Journal of Biological Chemistry, Baltimore, v.267, n.34, p.24207-24216, Dec.

REKHTER, M. D.(1999) Collagen synthesis in atherosclerosis: too much and not enough. Cardiovascular Research, v.41, p. 376-384.

RENA, R.J. (2003). A mulher e a osteoporose: como prevenir e tratar. São Paulo: Iátria.

RIANCHO, J.A.; GUTIÉRREZ, G.E. (2003). Factores regulatores de la reabsocion ósea. Revista Metabolismo Óseo y Mineral, Santander, v.1, n.2, p.51-66.

RODAN, G.A.; RODAN, S.B. (1983). Expresión of osteoblast phenotype. Bone Mineral Research, New York, v.2, p.244-262.

SCHAFFLER, M.B.; CHOI, K.; MILGROM, C. (1995). Aging and matrix microdamage accumulation in human compact bone. Bone, Elmsford, v.17, n.6, p.521-525, Dec.

SILVA, S.V. (2005). Mineralização biomimédica in vivo e in vitro de matrizes de colágeno aniônico: modelo de biomineralização. 115p. Tese (Doutorado)- Instituto de Química de São Carlos, Universidade de São Paulo, São Carlos, 2005.

SREENATH, T. et al. (2003). Dentin sialophosphoprotein knockout mouse teeth display widened predentin zone and develop defective dentin mineralization similar to human dentinogenesis inperfecta type III. Journal of Biological Chemistry, Baltimore, v.278, n.27, p.24874-24880, July. 
STELN, G.S.; LIAN, J.B.; OWEN, T.A. (1990). Relationship of cell growth to the regulation of tissue-specific gene expression during osteoblast differentiation. FASEB Journal, Bethesda, v.4, n.13, p.3111-3123, Oct.

SYKARAS, N.; OPPERMAN, L.A. (2003). Bone morphogenetic proteins (BMPs): how do they function and what can they offer the clinically. Journal of Oral Science, Tokyo, v.45, p.57-73.

TENÓRIO, D.M.H.; SANTOS, M.F.; ZORN, T.M.T. (2003). Distribution of biglycan and decorin in rat dental tissue. Brazilian Journal of Medical and Biological Research, Ribeirão Preto, v.36, n.8, p.1061-1065, Aug.

TORTORA, G.J.; GRABOWSKI, S.R. (2002). Princípios de anatomia e fisiologia. 9.ed. Rio de Janeiro: Guanabara Koogan.

ULRICH, P.; CERAMI, A. (2001). Protein glycation, diabetes, and aging. Recent Progress in Hormone Research, New York, v.56, p.1-21.

VERDE-CARVALHO, G.; GUARINO, A.; GONZALEZ, G. (2004). Ineralization of hydroxiapatite over collagen type I. European Cells and Materials, Clavedelstr, v.7, p.5859.

VIEIRA, E.C. et al. (1995). Química fisiológica. 2.ed. São Paulo: Atheneu.

VIIDIK, A.; VUUST, J. (1980). Biology of collagen. London: Academic Press.

WEINER, S.; TRAUB, W. (1986). Organization of hydroxyapatite crystals within collagen fibrils. Federation of European Biochemical Societies Lettersy, Amsterdam, v.206, n.2, p.262-266, Oct.

WEINSTEIN, S.L.; BUCKWALTER, J.A. (2000). Ortopedia de Turek: princípios e sua aplicação. 5 ed. São Paulo: Manole. v.1

WESS, T.J. et al. (1993). The in vivo glycation of diabetic tendon collagen studied by neutron diffraction. Journal of Molecular Biology, London, v.230, n.4, p.1297-1303, Apr.

WIESMANN, H.P. et al. (2001). Electrical stimulation Influences of mineral formation of osteoblast-like cells in vitro. Biochimica et Biophysica Acta, Amsterdam, v.1538, n.1, p.2837, Feb. 
WORLD HELTH ORGANIZATION STUDY GROUP (1994). Assessment of frature risk and its application to screening for postmenopausal osteoporosis. Geneva: World Health Organization. WHO Techinical Report Series nº 843. 


\section{GLOSSÁRIO}

3-deoxiglicosone: Metabólito da degradação do açúcar no tecido

Acetato de uranila: Sal de urânio derivado apartir do Ácido Acético.

Base de Shiff: é uma Keto-amina formada pela ligação de um aminoácido com um carboidrato.

Calcemia: quantidade de cálcio existente no sangue.

Carboximetil-lisina: aminoácido com um grupo carboxila e metil ligados na sua estrutura.

Fosforilação: Adição de um grupo fosfato a uma molécula.

Fosfotungstato de amônio: Sal de amônio derivado do ácido fosfórico e com um grupo tungstênio.

Glioxal: Metabólito da degradação do açúcar no tecido

Glucosil-Lisina: Composto de função orgânica mista sendo que a Lisina é um aminoácido e o radical glucosil é um carboidrato.

Hipogonadismo: Estado de insuficiência da secreção interna dos testículos ou dos ovários, quer por afecção primitiva destas glândulas quer por deficiência da função hipofisária.

Isomerização: transformação de um produto químico em um composto isômero, que é um composto químico formado pelos mesmos elementos, nas mesmas quantidade mas apresentando propriedades diferentes.

Keto-aminas: composto orgânico que apresenta cetona e amina como grupos funcionais.

Metilglioxal: Metabólito da degradação do açúcar no tecido 
Mieloma múltiplo: Tumor da medula óssea que aparece geralmente em vários ossos ao mesmo tempo.

Mimetizar: Tomar a estrutura de outro organismo ou do ambiente.

Motifs: Sítios de ligação

Racemização: Transformação de um composto opticamente ativo em uma forma racêmica.

Reação de Amadori: É a reação que transforma um aminoácido glucosilado em uma Keto amina.

Ribose: Açúcar com 5 carbonos na cadeia.

Síndrome de Cushing: Síndrome que resulta em obesidade centrípeta, faces pletóricas em "'lua cheia" , estrias cutâneas violáceas, atrofias musculares, astenia, diabetes, osteoporose , hipertensão e hipertricose. É causada por hiperplasia bilateral das supra-renais provocada por uma estimulação por quantidade excessiva de hormônio adrenocorticotrófico hipofisário.

Sistema de Micelas: Barreira de origem lipídica para controle do fluxo de água. 


\section{ANEXO I}

Planilha representativa da distribuição dos aminoácidos no período D quando cinco moléculas de colágeno são dispostas alternadamente de 1/4 de seu comprimento.

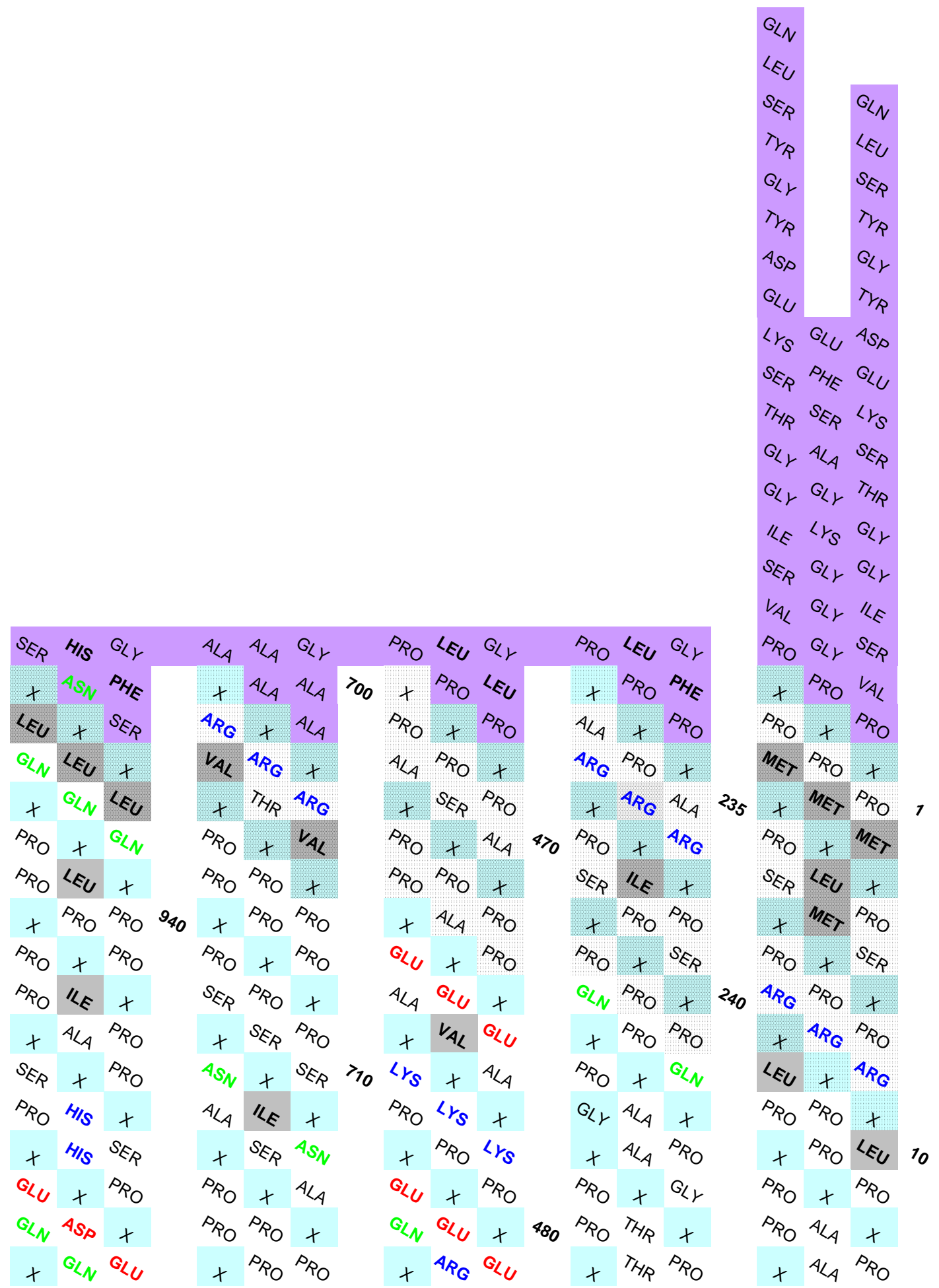




\begin{tabular}{|c|c|c|c|c|c|c|c|c|c|c|c|c|c|c|c|c|c|c|c|}
\hline$x$ & H/S & $S_{E P}$ & & $x$ & $s_{E p}$ & ${ }^{4} s_{N}$ & & + & ${ }^{A_{p_{O}}}$ & $\left\langle r_{s}\right.$ & & + & $A L_{A}$ & ${ }^{A_{P_{O}}}$ & & + & $s_{P_{O}}$ & E & zo \\
\hline$c_{<u}$ & + & $\Delta_{P_{O}}$ & & ${ }^{s_{P_{O}}}$ & + & $A<A$ & & $a_{L_{l}}$ & + & ${ }^{\Delta} P_{O}$ & & ${ }^{A_{P_{O}}}$ & + & $\sigma_{<r}$ & & ${ }^{s_{P_{O}}}$ & + & ${ }^{s_{P_{O}}}$ & \\
\hline$\sigma_{L_{N}}$ & ${ }^{4} s_{s}$ & + & & ${ }^{A_{P_{O}}}$ & ${ }^{A_{P_{O}}}$ & & & $Q_{L_{N}}$ & $\alpha_{l_{l}}$ & & $4_{80}$ & $A_{P_{O}}$ & $T_{\text {T/P }}$ & & & ${ }^{A_{P_{O}}}$ & $4 / 4$ & $x$ & \\
\hline+ & $\sigma_{L_{N}}$ & $a_{<l}$ & & + & $\Delta_{P_{O}}$ & $s_{P_{O}}$ & & + & ${ }^{A} \mathbb{P}_{G}$ & $a_{l l}$ & & + & $T_{\text {Y/P }}$ & ${ }^{s_{P_{O}}}$ & & + & $A_{A}$ & ${ }^{A_{P_{O}}}$ & \\
\hline${ }^{s_{P_{O}}}$ & + & $G_{L_{N}}$ & $9_{50}$ & $s_{p_{O}}$ & + & $s_{p_{O}}$ & & $v_{A /}$ & + & $\sigma_{L_{N}}$ & & $s_{p_{O}}$ & + & ${ }^{s_{P_{O}}}$ & & $A / A$ & + & ${ }^{s_{P_{O}}}$ & \\
\hline$s_{<p}$ & $4 / 4$ & + & & $s_{p_{O}}$ & $\Delta_{P_{O}}$ & + & & $A_{P_{O}}$ & $<E_{C}$ & & & $<r_{s}$ & $4 / 4$ & $x$ & & ${ }^{s_{P_{O}}}$ & $A / A$ & + & \\
\hline+ & ${ }^{A_{P O}}$ & ${ }^{s_{P_{O}}}$ & & + & ${ }_{P_{O}}$ & $s_{P_{O}}$ & & + & H/S & $v_{A K}$ & & + & ${ }^{4} \widehat{P}_{G}$ & ${ }^{\Delta_{P_{O}}}$ & 50 & + & ${ }^{s_{P_{O}}}$ & $4 / 4$ & \\
\hline $4 / 4$ & + & $s_{E p}$ & & ${ }_{P_{P O}}$ & + & ${ }^{O} P_{0}$ & & ${ }^{4} S_{S}$ & + & ${ }_{P_{O}}$ & & ${ }^{4} s_{N}$ & + & $\left\langle r_{s}\right.$ & & ${ }^{A_{P_{O}}}$ & + & ${ }^{N_{P_{O}}}$ & \\
\hline$s_{k p}$ & $s_{E P}$ & + & & $4 / 4$ & ${ }^{A_{P_{O}}}$ & 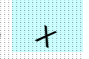 & 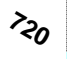 & LEQ & $a_{<l}$ & & & $s_{E_{p}}$ & $\angle E$ & & & $\sigma_{L_{N}}$ & ${ }^{A_{P_{O}}}$ & + & \\
\hline+ & $v_{A<}$ & $4 / 4$ & & + & $4 / 4$ & ${ }^{s_{P O}}$ & & + & D/PE & As & & + & $v_{A K}$ & ${ }^{4} s_{N}$ & & + & $\sigma_{<N}$ & ${ }^{A_{P_{O}}}$ & \\
\hline${ }_{P_{O}}$ & + & $s_{E p}$ & & $<r_{s}$ & + & $4<4$ & & $4 / 4$ & + & $\angle E_{C}$ & & $\theta_{<<}$ & + & $s_{s_{p}}$ & & $D_{\text {/SE }}$ & + & ${ }^{c}<_{N}$ & 20 \\
\hline $4<4$ & ${ }^{S_{P_{O}}}$ & + & & $a_{<<}$ & $\left\langle r_{s}\right.$ & . & & ${ }^{A_{P O}}$ & $\angle E$ & & & ${ }^{A_{P_{O}}}$ & $e_{<<}$ & & & $\sigma_{L N}$ & $D_{\text {MES }}$ & t & \\
\hline+ & $4 / 4$ & ${ }^{A_{P O}}$ & & + & $a_{<l}$ & $<r_{s}$ & & + & ${ }^{A_{P O}}$ & ${ }^{4}<4$ & ${ }^{4} 9_{0}$ & + & ${ }^{A_{P_{O}}}$ & ${ }^{a}<c$ & & + & $\sigma_{<N}$ & 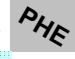 & \\
\hline${ }^{\mathrm{P}_{\mathrm{P}}}$ & + & $4 L_{4}$ & & $Q_{<r}$ & + & $a_{<c}$ & & ${ }^{A_{P_{O}}}$ & t & ${ }^{A_{P_{O}}}$ & & $A_{4}$ & t & ${ }^{P_{P_{O}}}$ & & ${ }^{A_{P_{O}}}$ & + & $c_{L_{N}}$ & \\
\hline${ }^{4} P_{G}$ & ${ }_{P_{P O}}$ & + & $9_{\sigma_{0}}$ & $\left\langle r_{s}\right.$ & $\angle E C$ & t & & $s_{E p}$ & $A_{P_{O}}$ & t & & ${ }^{A} P_{O}$ & ${ }^{A} P_{O}$ & + & & ${ }_{P_{P}}$ & ${ }_{P_{\mathrm{O}}}$ & + & \\
\hline+ & ${ }^{A} p_{G}$ & ${ }^{A_{P O}}$ & & $t$ & ${ }^{A} P_{G}$ & $\sigma_{<r}$ & & + & $4 / 4$ & ${ }^{A_{P O}}$ & & + & ${ }^{4} L_{4}$ & ${ }^{4} / 4$ & & + & $4<4$ & ${ }^{P_{P O}}$ & \\
\hline${ }^{P_{P_{O}}}$ & + & ${ }^{4} \uparrow_{G}$ & & $s_{P_{O}}$ & + & $<r_{s}$ & & $A K_{A}$ & + & $s_{E p}$ & & $s_{E p}$ & + & ${ }^{A_{P_{O}}}$ & $26_{0}$ & $a_{<<}$ & + & ${ }^{A_{P_{O}}}$ & \\
\hline${ }^{A_{p}}$ & ${ }^{A_{P_{O}}}$ & t & & ${ }^{4} p_{G}$ & ${ }^{A_{P_{O}}}$ & + & & ${ }^{4} P_{G}$ & $A_{P_{O}}$ & + & & $\left\langle r_{s}\right.$ & $s_{\text {Ep }}$ & + & & ${ }^{s_{P}}$ & $c_{<<}$ & + & \\
\hline+ & $4 / 4$ & ${ }^{s_{P O}}$ & & + & ${ }^{A} P_{G}$ & ${ }^{s_{P_{O}}}$ & $>30$ & + & ${ }^{4} p_{G}$ & $4<4$ & & + & $\left\langle r_{s}\right.$ & $s_{E_{p}}$ & & + & ${ }^{s_{P}}$ & ${ }^{a}<<$ & \\
\hline$s_{k p}$ & + & ${ }_{A_{P_{O}}}$ & & $a_{<<}$ & + & ${ }^{4} p_{G}$ & & $\sigma_{L_{l}}$ & + & ${ }^{4} \uparrow_{G}$ & & ${ }^{4} s_{s}$ & + & $<r_{s}$ & & $\sigma_{<l}$ & + & ${ }^{s_{P_{O}}}$ & \\
\hline$A K_{A}$ & $s_{P_{O}}$ & + & & $T_{\text {/ } / p}$ & ${ }^{4} s_{S}$ & t & & ${ }^{4} \widehat{P}_{G}$ & $\sigma_{<<}$ & + & & $T_{\text {H/P }}$ & $c_{<l}$ & + & & ${ }^{s_{P_{O}}}$ & $a_{<l}$ & + & 30 \\
\hline+ & $s_{E_{p}}$ & $S_{E_{p}}$ & & + & $\sigma_{<N}$ & $a_{<l}$ & & + & ${ }^{4} p_{G}$ & $a_{<c}$ & & + & $S_{E p}$ & ${ }^{4} s_{S}$ & & + & ${ }^{A_{P O}}$ & $a_{<c}$ & \\
\hline$A<A$ & $x$ & $A L_{A}$ & & ${ }^{s_{P_{O}}}$ & + & $T_{\text {YYP }}$ & & $D_{\text {//E }}$ & + & ${ }^{4} \widehat{P}_{G}$ & $5_{00}$ & $4<4$ & + & $T_{\text {t/p }}$ & & $4 / 4$ & + & ${ }^{s_{P_{O}}}$ & \\
\hline${ }^{A_{P_{O}}}$ & ${ }^{s_{P_{O}}}$ & + & & $A / 4$ & $\Delta_{p_{O}}$ & + & & ${ }^{s_{p_{O}}}$ & ${ }^{A} P_{O}$ & $t$ & & $\left\langle r_{s}\right.$ & ${ }^{4} s_{s}$ & t & & $s_{E p}$ & $\sigma_{L_{N}}$ & + & \\
\hline+ & $A_{4}$ & $A_{L_{A}}$ & $9>0$ & + & $4 / 4$ & ${ }^{s_{P_{O}}}$ & & + & ${ }^{s_{P_{O}}}$ & $\mathrm{D}_{\mathrm{K} / \mathrm{s}}$ & & + & <rs & $4<4$ & & + & $T_{\text {M/P }}$ & ${ }^{4}<4$ & \\
\hline$\left\langle r_{s}\right.$ & + & ${ }^{\Delta} P_{O}$ & & ${ }^{A} P_{G}$ & + & $A_{4}$ & & $a_{L_{l}}$ & + & $s_{p_{O}}$ & & $a_{L_{l}}$ & + & $<r_{s}$ & & ${ }^{s_{p_{O}}}$ & + & $s_{<p p}$ & \\
\hline${ }^{4} s_{S}$ & $\left\langle r_{s}\right.$ & + & & ${ }^{s_{P_{O}}}$ & ${ }^{A} \uparrow_{G}$ & + & & ${ }^{A} P_{G}$ & $\sigma_{<l}$ & + & & ${ }^{S_{P_{O}}}$ & $a_{L_{l}}$ & + & & $M_{E T}$ & ${ }^{A_{P_{O}}}$ & + & \\
\hline+ & $4_{s s}$ & <rs & & + & ${ }^{s_{P_{O}}}$ & ${ }^{A} \widehat{P}_{G}$ & & + & $s_{k p}$ & $a_{L u}$ & & + & ${ }^{\Delta} P_{O}$ & 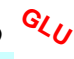 & & + & $4 L_{4}$ & ${ }^{\mathrm{S}_{\mathrm{P}}}$ & \\
\hline LEC & + & $A_{\text {ss }}$ & & $a_{<c}$ & + & ${ }_{D_{P}}$ & $>80$ & $v_{A_{L}}$ & + & ${ }^{4} \widehat{P}_{G}$ & & ${ }^{s_{P_{O}}}$ & + & $P_{O}$ & & ${ }^{s_{P_{O}}}$ & + & $\left.{ }^{\prime} \leqslant\right\rangle$ & \\
\hline${ }^{4} S_{N}$ & ${ }^{4} \hat{P}_{G}$ & + & & $V_{A L}$ & $a_{<c}$ & + & & $a_{L_{N}}$ & $A K_{4}$ & + & & $v_{A K}$ & $S_{\hat{E}_{p}}$ & + & & ${ }^{4} \widehat{P}_{G}$ & $A_{4}$ & + & \\
\hline+ & $T_{\text {Y/P }}$ & LEC & & + & $v_{A L}$ & $a_{<}$ & & + & $\sigma_{L N}$ & $v_{A L}$ & & + & ${ }^{4}<4$ & ${ }^{D_{p}}$ & & + & ${ }^{A} A_{G}$ & ${ }^{\infty} p_{O}$ & $4_{0}$ \\
\hline <Ec & + & ${ }^{4} s_{N}$ & & ${ }^{A} p_{O}$ & + & $v_{A L}$ & & ${ }^{\Delta} P_{O}$ & + & $\sigma_{L_{N}}$ & & $v_{A K}$ & + & $v_{A L}$ & & ${ }^{s_{P_{O}}}$ & + & ${ }^{4} \hat{P}_{G}$ & \\
\hline${ }^{A_{P_{O}}}$ & H/S & + & & ${ }^{\Delta} p_{O}$ & $A / A$ & + & & ${ }^{A_{P_{O}}}$ & ${ }^{D_{P_{O}}}$ & + & $s_{70}$ & $c_{L_{N}}$ & ${ }^{s_{p_{O}}}$ & + & & ${ }^{s_{p_{O}}}$ & ${ }^{s_{P_{O}}}$ & + & \\
\hline+ & ${ }^{P_{P}}$ & $\angle E$ & & + & ${ }_{P_{\mathrm{O}}}$ & ${ }^{s_{P_{O}}}$ & & + & $T_{\text {H/P }}$ & ${ }^{D_{P_{O}}}$ & & + & $\sigma_{<N}$ & $v_{A L}$ & & + & ${ }^{4} L_{4}$ & ${ }^{D_{P_{O}}}$ & \\
\hline${ }_{P_{O}}$ & + & ${ }^{\Delta} p_{O}$ & 980 & $s_{p_{O}}$ & + & $\Delta_{P_{O}}$ & & ${ }^{\Delta} p_{O}$ & + & $s_{p_{O}}$ & & $\Delta_{p_{O}}$ & + & $\sigma_{L_{N}}$ & & $s_{p_{O}}$ & + & $s_{p_{O}}$ & \\
\hline "स & $\lambda_{\text {M/p }}$ & t & & ${ }^{A_{P_{O}}}$ & ${ }^{D_{P_{O}}}$ & + & & $A_{4}$ & ${ }^{A_{P_{O}}}$ & 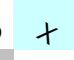 & & ${ }^{{ }^{P_{O}}}$ & ${ }^{s_{\mathrm{p}}}$ & + & & ${ }^{D_{P_{O}}}$ & ${ }^{s_{p_{O}}}$ & + & \\
\hline+ & $v_{A L}$ & ${ }^{D_{P O}}$ & & + & ${ }^{D_{\mathrm{P}}}$ & ${ }^{s_{p_{O}}}$ & & + & "E & ${ }^{s_{p}}$ & & + & ${ }^{s_{p}}$ & ${ }^{s_{p}}$ & 280 & + & ${ }^{s_{p}}$ & ${ }^{D_{p_{O}}}$ & \\
\hline${ }^{{ }^{P_{O}}}$ & + & "रE & & ${ }^{A_{P_{O}}}$ & + & ${ }^{A_{P_{O}}}$ & & ${ }^{A} P_{O}$ & + & ${ }^{A} K_{4}$ & & ${ }_{P_{O}}$ & + & ${ }^{D_{P_{O}}}$ & & $\left\langle r_{s}\right.$ & + & ${ }^{A_{P_{O}}}$ & \\
\hline${ }^{P_{P_{O}}}$ & ${ }^{s_{P_{O}}}$ & + & & $4 / 4$ & $\mathrm{O} / \mathrm{s}$ & t & $>s_{0}$ & ${ }^{4 P_{G}}$ & $s_{E p}$ & $t$ & & $4 K_{4}$ & ${ }^{A_{P_{O}}}$ & + & & ${ }^{4} S_{N}$ & $\left\langle r_{s}\right.$ & + & \\
\hline+ & ${ }^{4}<4$ & ${ }^{A_{P_{O}}}$ & & + & $4 / 4$ & ${ }^{\mathrm{s}} \mathrm{P}_{\mathrm{O}}$ & & + & ${ }^{4} P_{G}$ & ${ }^{s_{p}}$ & & + & ${ }^{\circ}$ Ep & ${ }^{s_{p}}$ & & + & ${ }^{4}<_{4}$ & $\left\langle r_{s}\right.$ & \\
\hline PिO & + & ${ }^{A_{P_{O}}}$ & & $a_{<l}$ & + & $A<A$ & & ${ }^{4} L_{4}$ & + & ${ }^{4} \uparrow_{G}$ & & $a_{<C}$ & + & $A<A$ & & ${ }^{4} s_{s}$ & + & ${ }^{4} s_{N}$ & 50 \\
\hline
\end{tabular}




\begin{tabular}{|c|c|c|c|c|c|c|c|c|c|c|c|c|c|c|c|c|c|c|c|c|}
\hline PO & $t$ & ${ }^{D_{P O}}$ & & $a_{<c}$ & + & $4<4$ & & $4<4$ & + & ${ }^{4} \mathbb{P}_{G}$ & & $a<c$ & + & $A<A$ & & ${ }^{4}$ So & + & ${ }^{4} s_{N}$ & 50 & bz \\
\hline Po & "रE & & & $<r_{s}$ & $a_{<<}$ & & & $4_{s_{N}}$ & ${ }^{A_{P_{O}}}$ & + & & $a_{<l}$ & $a_{<l}$ & 1 & & ${ }^{4} s_{S}$ & $\sigma_{</<}$ & + & & $b_{z}$ \\
\hline & ${ }^{4} \widehat{P}_{G}$ & 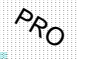 & & $x$ & $<r_{s}$ & $e_{<}$ & & + & $s_{E p}$ & $4<4$ & $s_{20}$ & + & $\sigma_{<l}$ & $a_{<}$ & & + & ${ }^{4} s_{0}$ & ${ }^{4} S_{D}$ & $z_{8}$ & $b_{2}$ \\
\hline & + & ${ }^{4} \widehat{P}_{G}$ & & $s_{\leqslant p}$ & + & $\left\langle r_{s}\right.$ & & $4<_{4}$ & + & ${ }^{4} s_{N}$ & & $\left\langle r_{s}\right.$ & + & $c_{<c}$ & & $c_{L_{C}}$ & + & $4_{s s}$ & & 6 \\
\hline t/p & $s_{P_{O}}$ & & $\vartheta_{\vartheta_{0}}$ & ${ }^{\Delta} p_{O}$ & ${ }^{s_{P_{O}}}$ & & & ${ }^{s_{P_{O}}}$ & ${ }^{A_{P_{O}}}$ & + & & ${ }^{4} P_{G}$ & $<r_{s}$ & & & $A L_{4}$ & H/s & t & & \\
\hline & $\sigma_{2 N}$ & ${ }^{4} P_{G}$ & & + & $s_{E, p}$ & $s_{k p}$ & & + & ${ }^{A_{P}}$ & $4<4$ & & + & ${ }^{A} P_{G}$ & $<r_{s}$ & & + & ${ }_{P_{P_{O}}}$ & $c_{<}$ & 20 & \\
\hline so & + & $T_{\text {r/p }}$ & & $4 L_{4}$ & + & ${ }^{s_{P_{O}}}$ & & ${ }^{4} s_{N}$ & + & ${ }^{s_{P_{O}}}$ & & $4 / 4$ & + & ${ }^{4} P_{G}$ & $29_{0}$ & $<r_{s}$ & + & $4<4$ & & b. \\
\hline 4 & H/S & + & & $4_{s s}$ & $a_{<<}$ & + & & ${ }^{4} s_{s}$ & ${ }^{A_{P_{O}}}$ & + & & ${ }^{4} P_{G}$ & ${ }^{A_{P_{O}}}$ & + & & ${ }^{s_{P_{O}}}$ & $<r_{s}$ & + & & $b_{2}$ \\
\hline 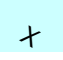 & $\sigma_{L_{N}}$ & ${ }^{4} s_{0}$ & & + & $4 / 4$ & $4<4$ & $>60$ & + & ${ }^{4} s_{S}$ & ${ }^{4} s_{\mathrm{N}}$ & & + & ${ }^{4} s_{N}$ & $4<4$ & & + & ${ }_{P_{P O}}$ & $<r_{s}$ & 20 & $b_{2}$ \\
\hline$P_{0}$ & + & $4 / 4$ & & ${ }^{s_{P_{O}}}$ & + & ${ }^{4} s_{S}$ & & $A_{<}$ & + & ${ }^{4} s_{s}$ & & $\sigma_{<l}$ & + & ${ }^{4} \uparrow_{G}$ & & ${ }^{4} p_{G}$ & & S$_{P_{O}}$ & & $b_{2}$ \\
\hline$Q_{<r}$ & $s_{p_{O}}$ & $x$ & & $4 L_{4}$ & $T_{1 / p}$ & $x$ & & $\left\langle r_{s}\right.$ & ${ }^{4} S_{N}$ & t & & ${ }^{s_{P_{O}}}$ & $a_{<l}$ & + & & ${ }_{P_{P}}$ & ${ }^{4} P_{G}$ & + & $\sigma_{0}$ & $b_{2}$ \\
\hline+ & $A / 4$ & ${ }^{s_{P_{O}}}$ & & + & $A K_{A}$ & ${ }^{s_{P_{O}}}$ & & + & $\left\langle r_{s}\right.$ & $4 / 4$ & & + & $4 K_{4}$ & $\sigma_{<c}$ & & $t$ & ${ }^{{ }^{p}}$ & ${ }^{4} p_{G}$ & $z_{2}$ & 6 \\
\hline${ }^{D_{P_{O}}}$ & + & $\sigma_{<r}$ & & $4 L_{4}$ & + & $4<A$ & & ${ }^{4} s_{S}$ & + & $<r_{s}$ & $5_{30}$ & ${ }^{s_{P_{O}}}$ & + & ${ }^{A_{P_{O}}}$ & & $Q_{L C}$ & + & ${ }^{A_{P_{O}}}$ & & 32 \\
\hline$P_{0}$ & $s_{P_{O}}$ & 1 & & ${ }^{\Delta} p_{O}$ & $s_{p_{O}}$ & + & & $A K_{A}$ & $a_{L_{l}}$ & 1 & & $T_{\text {/TP }}$ & $s_{E p}$ & + & & ${ }^{4} p_{G}$ & $Q_{L_{l}}$ & + & & 3 \\
\hline+ & ${ }^{A_{P_{O}}}$ & ${ }_{P_{\mathrm{O}}}$ & 0 & + & ${ }^{s_{p_{O}}}$ & $A<A$ & & + & ${ }^{A_{P_{O}}}$ & ${ }^{4} s_{s}$ & & + & $A L_{4}$ & ${ }^{P_{P_{O}}}$ & & + & ${ }^{4} \hat{P}_{G}$ & $\alpha_{<}$ & स् & \\
\hline$s_{P_{O}}$ & + & ${ }^{\Delta} p_{O}$ & & $T_{\text {M/p }}$ & + & $s_{p_{O}}$ & & $4 K_{A}$ & + & $A K_{A}$ & & $\angle E C$ & + & $T_{\text {r/p }}$ & & ${ }^{s_{P_{O}}}$ & & ${ }^{4} P_{G}$ & & \\
\hline${ }^{D_{P_{O}}}$ & ${ }^{D_{P_{O}}}$ & t & & ${ }^{s_{P_{O}}}$ & ${ }^{s_{P_{O}}}$ & + & & ${ }^{D_{P_{O}}}$ & $v_{A L}$ & + & & ${ }^{s_{P_{O}}}$ & ${ }^{A_{P_{O}}}$ & + & 300 & ${ }^{A_{P_{O}}}$ & $v_{A / L}$ & + & & \\
\hline+ & $s_{P_{O}}$ & ${ }^{\Delta} P_{O}$ & & + & $T_{\text {r/p }}$ & $T_{\text {trp }}$ & & + & $v_{A k}$ & $4<A$ & & + & ${ }^{A_{P_{O}}}$ & $\angle E C$ & & + & $v_{A / L}$ & ${ }^{A_{P O}}$ & $z_{3}$ & \\
\hline${ }^{D_{P_{O}}}$ & + & ${ }^{A_{P_{O}}}$ & & ${ }^{s_{P_{O}}}$ & + & ${ }^{D_{P_{O}}}$ & 0 & $4<_{4}$ & + & ${ }^{A_{P_{O}}}$ & & ${ }^{s_{P_{O}}}$ & + & ${ }^{A_{P_{O}}}$ & & ${ }^{A_{P_{O}}}$ & + & ${ }^{A_{P_{O}}}$ & & \\
\hline$P_{0}$ & $s_{p_{O}}$ & + & & $a_{L_{N}}$ & $s_{p_{O}}$ & + & & ${ }^{s_{P_{O}}}$ & $A<A$ & + & & $s_{p_{O}}$ & ${ }^{s_{P_{O}}}$ & + & & $\sigma_{L_{N}}$ & ${ }^{A_{p_{O}}}$ & + & & \\
\hline+ & ${ }_{P_{P_{O}}}$ & $D_{D}$ & & + & $\sigma_{L_{N}}$ & $s_{p_{O}}$ & & + & ${ }^{\Delta} P_{O}$ & $A K_{A}$ & & + & ${ }^{A} P_{O}$ & $D_{P_{O}}$ & & + & $\sigma_{L_{N}}$ & ${ }^{A_{P_{O}}}$ & $>0$ & \\
\hline${ }_{P_{O}}$ & + & ${ }^{\Delta} p_{O}$ & & "रE & + & $c_{L_{N}}$ & & $s_{\varepsilon p}$ & + & $s_{p_{O}}$ & & $a_{L_{l}}$ & + & $s_{P_{O}}$ & & $A / 4$ & + & $\sigma_{L_{N}}$ & & 84 \\
\hline${ }^{D_{P O}}$ & ${ }^{A_{P_{O}}}$ & $x$ & & $4 / 4$ & KEC & + & & $a_{/ N}$ & $T_{\text {Y/P }}$ & + & $s_{80}$ & ${ }^{4} \widehat{P}_{G}$ & LEC & + & & ${ }^{A} \hat{P}_{G}$ & $A / 4$ & + & & 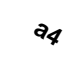 \\
\hline+ & ${ }_{P_{P_{O}}}$ & ${ }^{A} P_{O}$ & & + & LEC & " यE & & + & $A<A$ & $s_{k p}$ & & + & ${ }^{A} P_{G}$ & $a_{L l}$ & & + & ${ }^{A} \mathbb{P}_{G}$ & $A K_{A}$ & & $a_{<}$ \\
\hline${ }^{P_{P O}}$ & t & ${ }^{A_{P_{O}}}$ & ${ }^{2} \mathrm{O}_{0}$ & $c_{L N}$ & + & $A<A$ & & $A / A$ & + & $c_{<N}$ & & $\sigma_{L_{r}}$ & + & ${ }^{4} \widehat{P}_{G}$ & & $\angle E_{C}$ & + & ${ }^{4} \mathbb{P}_{G}$ & & $a_{<}$ \\
\hline${ }^{P_{P O}}$ & $v_{A_{L}}$ & $x$ & & ${ }^{4} \uparrow_{G}$ & $4 / 4$ & $x$ & & ${ }^{D_{p_{O}}}$ & ${ }^{s_{P_{O}}}$ & + & & $s_{p_{O}}$ & $s_{E_{p}}$ & + & & ${ }^{s_{p_{O}}}$ & $D_{\text {/ME }}$ & + & & $a_{4}$ \\
\hline 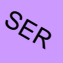 & $s_{E p}$ & ${ }^{A_{P_{O}}}$ & & $t$ & ${ }^{A_{P}}$ & $a_{2} c_{N}$ & & + & $s_{E P}$ & $4<A$ & & + & ${ }^{s_{P_{O}}}$ & $\sigma_{<r}$ & to & + & $A_{p_{O}}$ & $\angle E C$ & & $\partial_{4}$ \\
\hline & $G_{L r}$ & ${ }_{P_{P O}}$ & & $v_{A L}$ & + & ${ }^{4} \hat{P}_{G}$ & & $\angle E C$ & + & ${ }^{A_{P_{O}}}$ & & $s_{E p}$ & + & ${ }^{A_{P_{O}}}$ & & $T_{\text {H/P }}$ & + & ${ }^{A_{P_{O}}}$ & & $Q_{4}$ \\
\hline 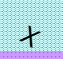 & $\sigma_{l r}$ & $s_{E_{p}}$ & & $v_{A L}$ & "रE & t & $>80$ & ${ }^{a} / N$ & ${ }^{A_{P O}}$ & + & & ${ }^{4 P_{G}}$ & $s_{E p}$ & + & & $A L_{A}$ & $T_{\text {r/p }}$ & + & & \\
\hline $0 / / 5$ & + & $A / 4$ & & + & <EC & $v_{A L}$ & & + & $s_{E p}$ & $<E C$ & & + & ${ }^{A} P_{G}$ & $s_{E_{P}}$ & & + & $A_{P_{O}}$ & $T_{\text {T/P }}$ & & \\
\hline${ }^{4} s_{S}$ & $\lambda_{r_{p}}$ & $x$ & & LEv & + & $v_{A L}$ & & $m_{E>}$ & + & $a_{L / N}$ & & $D_{\text {M/E }}$ & + & ${ }^{4} P_{G}$ & & $\angle E_{C}$ & + & $A<A$ & 80 & \\
\hline${ } E_{C}$ & $a_{<l}$ & $D^{2 / 4}$ & & $s_{P_{O}}$ & $\angle E_{C}$ & + & & ${ }^{s_{P_{O}}}$ & LEC & + & & ${ }^{A_{P_{O}}}$ & $\angle E C$ & + & & ${ }^{s_{P_{O}}}$ & $\angle E$ & + & & \\
\hline UEP & $\mathrm{O} / \mathrm{s}$ & ${ }^{4}$ So & & + & ${ }^{A} P_{O}$ & $\angle E C$ & & + & ${ }^{A_{P O}}$ & $m_{E T}$ & 550 & + & ${ }^{s_{P_{O}}}$ & $D_{\text {ME }}$ & & + & $A_{P_{O}}$ & $\angle E$ & & \\
\hline rs & 0 & & & + & ${ }^{\Delta} p_{O}$ & $D^{2 / 4}$ & & + & ${ }^{\Delta} P_{O}$ & $\angle E C$ & & + & MET & ${ }^{A_{P_{O}}}$ & & + & ${ }^{4} s_{N}$ & $D_{\text {//E }}$ & & \\
\hline 1 & 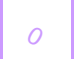 & -20 & & $\angle E C$ & + & ${ }^{s_{P_{O}}}$ & & ${ }^{D_{P_{O}}}$ & + & ${ }^{D_{P O}}$ & $s_{6_{0}}$ & ${ }^{\Delta_{P O}}$ & + & L rs & & $\angle E$ & + & $s_{E_{p}}$ & & \\
\hline $4 / 5$ & 0 & $\left\langle r_{s}\right.$ & & ${ }^{D_{P_{O}}}$ & $V_{A K}$ & + & & $<r_{s}$ & $\sigma_{<r}$ & + & & $A_{4}$ & ${ }^{A_{P_{O}}}$ & t & & ${ }^{4} S_{D}$ & $\angle E_{C}$ & + & & \\
\hline מא & 0 & $4 / 4$ & & + & $A_{4}$ & KE & & + & $\left\langle r_{s}\right.$ & ${ }^{s_{p_{O}}}$ & & + & $A_{4}$ & ${ }^{s_{p_{O}}}$ & & + & ${ }^{4} S_{S}$ & LEC & & \\
\hline$a_{L_{r}}$ & 0 & $\mathrm{H} / \mathrm{S}$ & & ${ }^{A_{P_{O}}}$ & + & ${ }^{s_{P_{O}}}$ & & ${ }^{4} S_{S}$ & + & $\left\langle r_{s}\right.$ & & $a_{<c}$ & + & $4 / 4$ & & $A<4$ & + & ${ }^{4} s_{0}$ & & Q2 \\
\hline G & 0 & ${ }^{4} S_{S}$ & & $s_{E_{p}}$ & ${ }^{A_{P_{O}}}$ & + & & ${ }^{4} \widehat{P}_{G}$ & $a_{L l}$ & + & & ${ }^{A P_{G}}$ & $s_{E_{p}}$ & + & $3_{30}$ & $\left\langle r_{s}\right.$ & $\angle E$ & + & & क्य \\
\hline 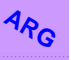 & 0 & $\sigma_{<r}$ & & $t$ & $v_{A K}$ & ${ }^{s_{P_{O}}}$ & & + & $\left\langle r_{s}\right.$ & ${ }^{4} s_{s}$ & & + & ${ }^{4} P_{G}$ & $\sigma_{L_{l}}$ & & + & $<r_{s}$ & $A K_{A}$ & & Q2 \\
\hline$r_{p}$ & 0 & $G_{L r}$ & & $a_{<<}$ & + & $s_{E p}$ & 0 & ${ }^{4} s_{D}$ & + & ${ }^{4} \hat{P}_{G}$ & & $s_{E, p}$ & + & ${ }^{A} p_{G}$ & & ${ }^{4} s_{D}$ & + & $\left\langle r_{s}\right.$ & & क् \\
\hline$r_{r_{p}}$ & 0 & ${ }^{4} \hat{P}_{G}$ & & ${ }^{\Delta} p_{O}$ & $c_{<c}$ & + & & $A / 4$ & $a_{<c}$ & + & & ${ }^{D_{P_{O}}}$ & $A_{4}$ & + & & $A K_{4}$ & $\sigma_{L_{N}}$ & + & & स् $_{2}$ \\
\hline$r_{r_{p}}$ & 0 & $r_{r_{p}}$ & & + & ${ }^{\Delta} p_{O}$ & $\sigma_{L_{l}}$ & & + & ${ }^{s_{P_{O}}}$ & ${ }^{4} s_{D}$ & & + & $s_{E p}$ & $s_{\varepsilon_{p}}$ & & + & $D_{p_{O}}$ & ${ }^{4} s_{D}$ & 800 & \\
\hline
\end{tabular}




\begin{tabular}{|c|c|c|c|c|c|c|c|c|c|c|c|c|c|c|c|c|c|c|c|}
\hline & & $r_{p}$ & + & ${ }^{\Delta} p_{O}$ & $a_{L_{c}}$ & & + & ${ }^{A_{P_{O}}}$ & $A_{S S}$ & & $t$ & $s_{E P}$ & $s_{E_{P}}$ & & + & ${ }^{\Delta_{P_{O}}}$ & $4_{S D}$ & 200 & z \\
\hline & 0 & $r_{p}$ & $\left\langle r_{s}\right.$ & + & ${ }^{D_{P_{O}}}$ & & ${ }^{\Delta_{P_{O}}}$ & + & $A L_{A}$ & & ${ }^{\Delta} p_{O}$ & + & ${ }_{P_{P_{O}}}$ & & ${ }^{s_{P_{O}}}$ & + & $A<A$ & & $\partial$ \\
\hline & & & $\sigma_{L_{N}}$ & ${ }^{D_{P_{O}}}$ & + & & $\left\langle r_{s}\right.$ & $\angle E_{C}$ & + & $5>0$ & $A<A$ & $D_{P_{O}}$ & & & $4 / 4$ & $A K_{A}$ & + & & \\
\hline & 0 & 0 & + & $\angle E C$ & $\left\langle r_{s}\right.$ & & + & ${ }^{4} \widehat{P}_{G}$ & $\Delta_{P_{O}}$ & & + & $4 / 4$ & ${ }_{P_{P_{O}}}$ & & + & $\Delta_{p_{O}}$ & ${ }^{\Delta} p_{O}$ & & \\
\hline & 0 & 0 & ${ }^{A_{P_{O}}}$ & + & $Q_{L_{N}}$ & & $A L_{A}$ & + & $\left\langle r_{s}\right.$ & & ${ }^{s_{p_{O}}}$ & + & $A / 4$ & & ${ }^{A_{P_{O}}}$ & + & $A<A$ & & \\
\hline C & 0 & 0 & $s_{E_{p}}$ & "E & + & & ${ }^{4} s_{S D}$ & $a_{L_{l}}$ & + & & $\left\langle r_{s}\right.$ & $v_{A k}$ & & & $\left\langle r_{s}\right.$ & $v_{A L}$ & + & & \\
\hline & 0 & 0 & + & $s_{E_{p}}$ & ${ }^{A_{P_{O}}}$ & & + & यE & $A / 4$ & & + & ${ }^{4} P_{G}$ & ${ }^{D_{P_{O}}}$ & $3_{80}$ & $x$ & $\left\langle r_{s}\right.$ & $A_{P_{O}}$ & & \\
\hline$c$ & 0 & 0 & $4<_{4}$ & + & $s_{E p}$ & & $s_{s_{p}}$ & + & ${ }^{4} s_{s}$ & & $s_{E p}$ & + & $<r_{s}$ & & $\sigma_{L_{u}}$ & + & $\left\langle r_{s}\right.$ & & \\
\hline & 0 & 0 & $s_{k p}$ & ${ }^{D_{P_{O}}}$ & + & $8_{70}$ & ${ }^{D_{P_{O}}}$ & ${ }^{4} \mathrm{sll}_{\mathrm{N}}$ & + & & ${ }^{A_{P_{O}}}$ & $A_{P_{O}}$ & + & & ${ }^{D_{P_{O}}}$ & $\sigma_{<<}$ & + & & \\
\hline & 0 & 0 & + & ${ }^{D_{P_{O}}}$ & $4 L_{4}$ & & + & ${ }^{A_{P O}}$ & $s_{E_{p}}$ & & + & ${ }^{4} s_{n}$ & $s_{E_{p}}$ & & + & ${ }_{A_{P_{O}}}$ & $\sigma_{L_{L}}$ & & \\
\hline C & 0 & 0 & $c_{<<}$ & + & $s_{k p}$ & & $\left\langle r_{s}\right.$ & + & ${ }^{A_{P_{O}}}$ & & $c_{<<}$ & + & ${ }_{P_{P}}$ & & $s_{k p}$ & + & $A_{P_{O}}$ & $x_{20}$ & \\
\hline c & 0 & 0 & ${ }^{4} P_{G}$ & $4<4$ & + & & $4_{S_{D}}$ & ${ }^{4} \widehat{P}_{G}$ & + & & $4<4$ & ${ }^{4} S_{S}$ & & & ${ }^{s_{P_{O}}}$ & ${ }^{4} C_{4}$ & + & & \\
\hline c & 0 & 0 & + & ${ }^{4} p_{G}$ & $c_{<<}$ & & + & ${ }^{4} s_{S O}$ & $\left\langle r_{s}\right.$ & $5_{80}$ & + & $4 / 4$ & $a_{L_{l}}$ & & + & ${ }^{S_{P_{O}}}$ & $s_{E_{p}}$ & & \\
\hline$c$ & 0 & 0 & $s_{p_{O}}$ & + & ${ }^{4} P_{G}$ & & $v_{A_{L}}$ & + & $4_{S s}$ & & ${ }^{4} \hat{P}_{G}$ & + & $4 L_{4}$ & & $\sigma_{<c}$ & + & ${ }^{A_{P_{O}}}$ & & \\
\hline 0 & 0 & 0 & ${ }^{s_{p_{O}}}$ & ${ }^{A} P_{O}$ & + & & ${ }^{4} P_{G}$ & $4 / 4$ & + & & $s_{P_{O}}$ & ${ }^{4} P_{G}$ & & & ${ }^{4} S_{\mathrm{N}}$ & $a_{<c}$ & $x$ & & \\
\hline$c$ & 0 & 0 & + & ${ }^{D_{P_{O}}}$ & ${ }^{D_{P_{O}}}$ & & + & $4 p_{G}$ & $v_{A L}$ & & + & ${ }^{D_{P O}}$ & $4 \mathbb{P}_{G}$ & & + & $A_{s, ~}$ & $a_{<c}$ & & \\
\hline 0 & 0 & 0 & ${ }^{\Delta} p_{O}$ & + & $s_{P_{O}}$ & & LEC & + & ${ }^{4} P_{G}$ & & $e_{<<}$ & + & $D_{P_{O}}$ & $3_{50}$ & $4 / 4$ & + & ${ }^{4}{ }_{S N}$ & & \\
\hline 0 & 0 & 0 & MET $_{\text {ET }}$ & $4<4$ & + & & $T_{\text {Y/P }}$ & $4 / 4$ & + & & $4<A$ & $a_{L_{C}}$ & + & & ${ }^{A_{P_{O}}}$ & $T_{\text {M/P }}$ & + & & \\
\hline 0 & 0 & 0 & + & $v_{A K}$ & ${ }^{A} P_{O}$ & $8_{20}$ & + & H/S & $\angle E_{C}$ & & + & ${ }_{P_{P_{O}}}$ & $c_{<l}$ & & + & ${ }^{A_{P O}}$ & ${ }^{4} L_{A}$ & & \\
\hline 0 & 0 & 0 & $s_{p_{O}}$ & + & $M_{E T}$ & & $s_{P_{O}}$ & + & $T_{\text {M/P }}$ & & $\angle E C$ & + & $4 / 4$ & & $c_{<N}$ & + & ${ }^{A_{P_{O}}}$ & & \\
\hline 0 & 0 & 0 & $\Delta_{p_{O}}$ & $S_{E p}$ & + & & " & $4 / 4$ & + & & ${ }_{P_{O}}$ & $\angle E C$ & & & $m_{E \lambda}$ & $c_{2 N}$ & + & $x_{20}$ & \\
\hline 0 & 0 & 0 & + & ${ }^{A_{P_{O}}}$ & ${ }^{A} P_{O}$ & & $t$ & $v_{A L}$ & ${ }^{s_{P O}}$ & & + & $M_{E T}$ & $\angle E C$ & & + & $T_{\text {M/P }}$ & $c^{c_{2}}$ & & \\
\hline 0 & 0 & 0 & $\angle E C$ & + & $s_{P_{O}}$ & & $s_{P_{O}}$ & + & "रE & $s_{90}$ & $4 K_{A}$ & + & ${ }_{P_{P_{O}}}$ & & $\mathrm{~s}_{\mathrm{P}_{\mathrm{O}}}$ & + & & & \\
\hline 0 & 0 & 0 & $A L_{A}$ & $v_{A L}$ & + & & ${ }^{s_{P_{O}}}$ & $A L_{A}$ & + & & $\left\langle r_{s}\right.$ & ${ }_{P_{P_{O}}}$ & + & & ${ }^{4} \mathbb{P}_{G}$ & ${ }^{4} L_{4}$ & + & & \\
\hline 0 & 0 & 0 & + & ${ }^{4} S_{S N}$ & $\angle E_{C}$ & & $t$ & ${ }^{S_{P_{O}}}$ & ${ }^{s_{P_{O}}}$ & & + & $4 \hat{P}_{G}$ & $A L_{A}$ & & + & ${ }^{4} P_{G}$ & ${ }_{P_{P O}}$ & & \\
\hline 0 & 0 & 0 & ${ }^{A_{P_{O}}}$ & + & $A<A$ & & ${ }^{D_{P_{O}}}$ & + & ${ }^{A_{P_{O}}}$ & & $\angle E_{C}$ & + & $\left\langle r_{s}\right.$ & & $<E_{C}$ & + & ${ }^{4} \widehat{A}_{G}$ & & \\
\hline 0 & 0 & 0 & $\Delta_{p_{O}}$ & $A L_{A}$ & + & & $A L_{A}$ & ${ }^{A_{P_{O}}}$ & + & & $T_{\text {M/P }}$ & $\angle E$ & + & $3_{60}$ & $\mathrm{~s}_{\mathrm{P}_{0}}$ & LEC & + & & \\
\hline 0 & 0 & 0 & + & ${ }_{A_{P_{O}}}$ & ${ }^{A} P_{O}$ & & + & $4 / 4$ & ${ }^{s_{P_{O}}}$ & & + & ${ }_{s_{P_{O}}}$ & $\angle E C$ & & + & ${ }^{A} P_{O}$ & $\angle E_{Q}$ & & \\
\hline 0 & 0 & 0 & $c_{L_{c}}$ & + & $s_{P_{O}}$ & 830 & $A L_{A}$ & + & $A L_{A}$ & & $s_{E_{p}}$ & + & $T_{\text {H/P }}$ & & $c_{<l}$ & + & $D_{P_{O}}$ & & \\
\hline 0 & 0 & 0 & $s_{E_{p}}$ & $c_{<l}$ & + & & ${ }^{D_{P_{O}}}$ & $4 K_{4}$ & + & & ${ }^{A_{P_{O}}}$ & $s_{E_{p}}$ & + & & $4 P_{G}$ & $\sigma_{<l}$ & + & & \\
\hline 0 & 0 & 0 & + & $A / 4$ & $a_{<c}$ & & + & $T_{\text {H/P }}$ & $A_{4}$ & & + & $s_{P_{O}}$ & $s_{E_{P}}$ & & + & ${ }^{A} P_{G}$ & $a_{L_{l}}$ & $x_{30}$ & \\
\hline 0 & 0 & 0 & $x$ & $A<A$ & $c_{<l}$ & & $x$ & $r_{\text {Y/P }}$ & $A<A$ & & + & ${ }^{A} P_{O}$ & $s_{E_{p}}$ & & + & ${ }^{4} \widehat{P}_{G}$ & $a_{<l<}$ & 230 & $e_{j}$ \\
\hline 0 & 0 & 0 & $4 P_{G}$ & + & $s_{E_{P}}$ & & $A_{S D}$ & + & ${ }_{P_{P O}}$ & & $s_{E_{p}}$ & + & ${ }_{P_{P_{O}}}$ & & $4 \mathbb{P}_{G}$ & + & ${ }^{A A_{G}}$ & & \\
\hline 0 & 0 & 0 & $\sigma_{<<}$ & $4 \hat{P}_{G}$ & + & & $\left\langle r_{s}\right.$ & $A_{s}$ & + & $\sigma_{00}$ & ${ }^{A_{P_{O}}}$ & $A_{S N}$ & + & & ${ }^{s_{P_{O}}}$ & $4 \widehat{P}_{G}$ & + & & \\
\hline 0 & 0 & 0 & + & $4_{S O}$ & ${ }^{4} P_{G}$ & & $x$ & ${ }^{A} P_{G}$ & $4_{s s}$ & & + & "रE & $s_{E_{p}}$ & & + & $v_{A L}$ & $4 \widehat{A}_{G}$ & & \\
\hline 0 & 0 & 0 & ${ }^{4} L_{4}$ & + & $a_{<c}$ & & $a_{L_{l}}$ & + & $<r_{s}$ & & $s_{p_{O}}$ & + & ${ }_{P_{O}}$ & & $A_{4}$ & + & $s_{p_{O}}$ & & \\
\hline 0 & 0 & 0 & ${ }_{P_{P O}}$ & $A_{S N}$ & + & & $s_{E_{p}}$ & $\sigma_{L_{l}}$ & + & & ${ }^{4} s_{s}$ & ${ }^{A_{P_{O}}}$ & + & & ${ }^{s_{P_{O}}}$ & $4 L_{A}$ & + & & \\
\hline 0 & 0 & 0 & + & ${ }^{\Delta} P_{O}$ & $4 / 4$ & & + & ${ }^{4} / 4$ & $a_{<u}$ & & + & $4 / 4$ & $D_{P_{O}}$ & $3>0$ & + & $s_{P_{O}}$ & $A / 4$ & & \\
\hline 0 & 0 & 0 & $4 L_{4}$ & + & ${ }^{A_{P_{O}}}$ & & ${ }^{S_{P_{O}}}$ & + & $s_{k p}$ & & $\left\langle r_{s}\right.$ & + & ${ }^{4} s_{s}$ & & ${ }^{s_{p_{O}}}$ & + & $A_{p_{O}}$ & & \\
\hline 0 & 0 & 0 & $a_{<u}$ & ${ }^{4} s_{N}$ & + & $8_{80}$ & $s_{\Sigma_{p}}$ & $4 L_{4}$ & + & & $r_{\text {r/p }}$ & $\left\langle r_{s}\right.$ & + & & $A<A$ & ${ }^{D_{P_{O}}}$ & + & & \\
\hline d & 0 & 0 & + & ${ }^{4} s_{S O}$ & $4 L_{4}$ & & + & $4 L_{4}$ & ${ }^{\Delta} p_{P_{O}}$ & & + & $a_{<l}$ & $<r_{s}$ & & + & $4<4$ & $A_{p_{O}}$ & & \\
\hline & 0 & 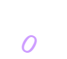 & $s_{E p}$ & + & $c_{<<}$ & & ${ }^{A_{P_{O}}}$ & + & $s_{E P}$ & & ${ }_{P_{P O}}$ & + & $T_{\text {t/p }}$ & & $4<4$ & + & $4 L_{4}$ & $x_{40}$ & \\
\hline
\end{tabular}




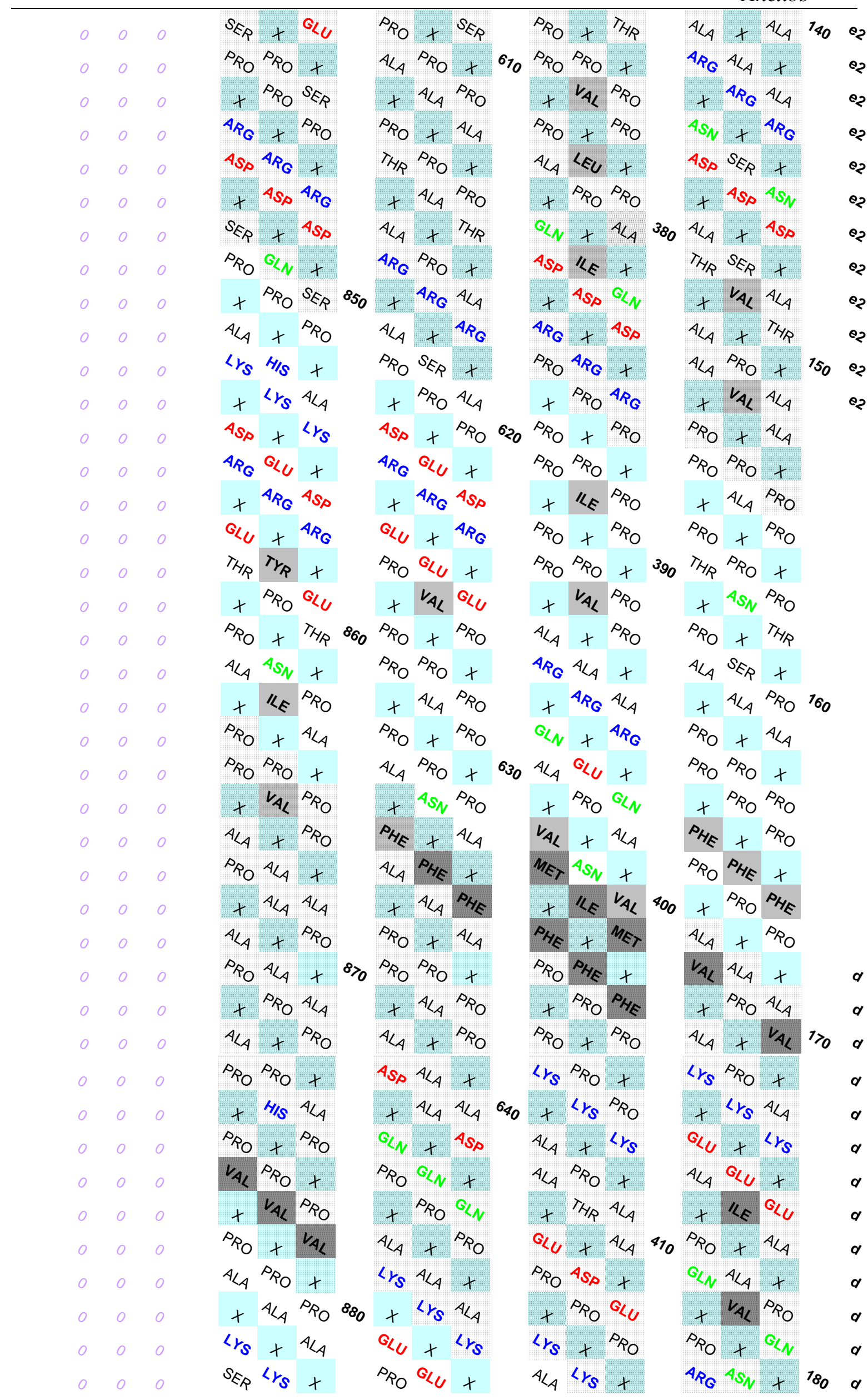




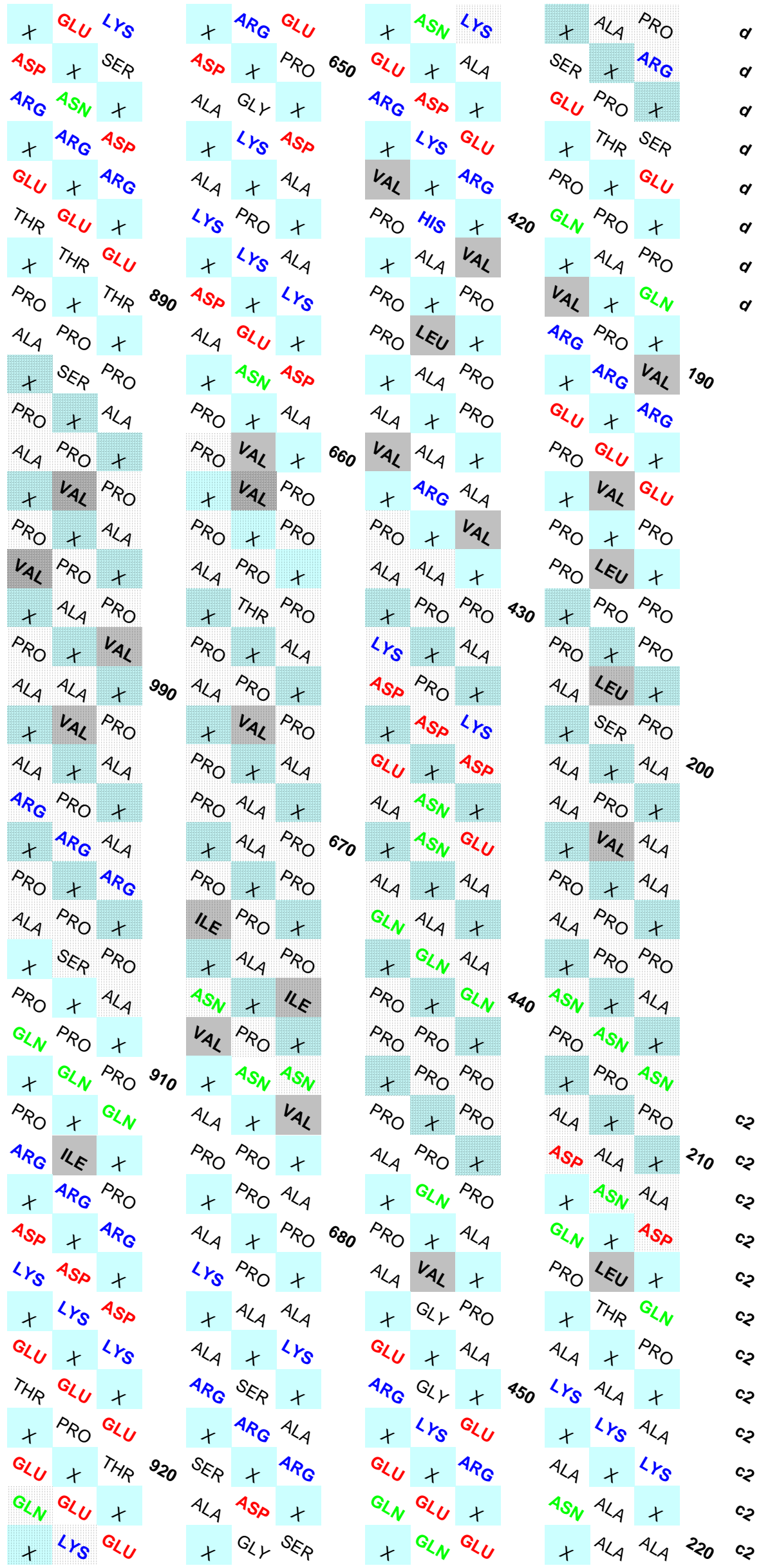




\begin{tabular}{|c|c|c|c|c|c|c|c|c|c|c|c|c|c|c|c|}
\hline+ & $\left\langle r_{s}\right.$ & $a_{L_{c}}$ & & + & $\sigma_{<r}$ & $S_{E p}$ & & + & $\sigma_{L_{N}}$ & $\sigma_{L_{l}}$ & & + & $A<A$ & $A_{4}$ & स्स० \\
\hline${ }^{4} s_{S}$ & + & $c_{L_{N}}$ & & ${ }^{\Delta} p_{O}$ & + & $4 L_{4}$ & & ${ }^{s_{P_{O}}}$ & + & $c_{L_{N}}$ & & $A_{\Delta A}$ & $t$ & ${ }^{4} s_{N}$ & \\
\hline${ }^{4} \widehat{P}_{G}$ & ${ }^{A_{P_{O}}}$ & $t$ & & ${ }^{\Delta_{P_{O}}}$ & ${ }^{A_{P O}}$ & $x$ & $\sigma_{90}$ & ${ }^{A} K_{A}$ & ${ }^{s_{P_{O}}}$ & 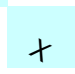 & & ${ }^{s_{P_{O}}}$ & $<E$ & & \\
\hline+ & ${ }^{A} P_{G}$ & ${ }^{4} s_{S}$ & & + & ${ }^{s_{P_{O}}}$ & ${ }^{A_{P_{O}}}$ & & + & $A<A$ & ${ }^{s_{P_{O}}}$ & & + & ${ }_{P_{O}}$ & $A L_{A}$ & \\
\hline "रE & + & ${ }^{4} p_{G}$ & & $4 / 4$ & + & ${ }_{P_{P O}}$ & & $s_{E p}$ & + & $A L_{A}$ & & यE & + & ${ }^{s_{P_{O}}}$ & \\
\hline$\left\langle r_{s}\right.$ & <EC & $x$ & & $T_{\text {T/p }}$ & $M_{E T}$ & $t$ & & ${ }^{A_{P_{O}}}$ & ${ }^{s_{P_{O}}}$ & $t$ & & $A_{4}$ & $v_{A K}$ & + & \\
\hline+ & ${ }^{s_{P O}}$ & यE & & $t$ & $T_{\text {M/p }}$ & $A / 4$ & & + & ${ }^{\Delta} p_{O}$ & $s_{E p}$ & ${ }^{4} \sigma_{0}$ & + & $4 / 4$ & "सE & \\
\hline $\mathrm{H} / \mathrm{s}$ & + & $\left\langle r_{s}\right.$ & & $A_{\text {/HE }}$ & + & $T_{\text {/TP }}$ & & $D_{\text {//F }}$ & + & ${ }^{s_{P_{O}}}$ & & ${ }^{4}<A$ & $t$ & $4<4$ & \\
\hline${ }^{4} P_{G}$ & $D_{1 / 2}$ & + & $9_{30}$ & ${ }^{s_{P_{O}}}$ & $\mathrm{O} / \mathrm{s}$ & $t$ & & ${ }^{a} L_{N}$ & $D_{\text {/ME }}$ & + & & $s_{p_{O}}$ & $4 L_{4}$ & + & \\
\hline+ & $<r_{s}$ & $\mathrm{H} / \mathrm{S}$ & & $t$ & ${ }^{A_{P_{O}}}$ & D/4E & & + & $\alpha_{2 N}$ & $D_{1 / 5}$ & & $x$ & ${ }^{A_{P_{O}}}$ & $4<_{4}$ & \\
\hline $\mathrm{S}_{\text {公 }}$ & + & $4 p_{G}$ & & $4<4$ & + & ${ }_{P_{P O}}$ & & ${ }^{s_{P_{O}}}$ & + & $c_{<N}$ & & D/PE & $t$ & ${ }^{A_{P O}}$ & 230 \\
\hline$s_{<p}$ & H/s & + & & $4 / 4$ & $A_{4}$ & + & & ${ }^{s_{P_{O}}}$ & $<E$ & $t$ & & ${ }^{s_{P_{O}}}$ & $<E$ & $1+$ & \\
\hline 0 & ${ }^{4} S_{1}$ & $D_{\text {/ }} / 5$ & & 0 & $4 L_{4}$ & $4 / 4$ & & 0 & ${ }^{s_{P_{O}}}$ & $s_{P_{O}}$ & & 0 & ${ }^{s_{P_{O}}}$ & $D_{\text {/ } / E}$ & \\
\hline 0 & 0 & $s_{E p}$ & & 0 & 0 & ${ }^{4} L_{4}$ & & 0 & 0 & ${ }^{D_{P_{O}}}$ & & 0 & 0 & ${ }^{{ }_{P}}$ & \\
\hline
\end{tabular}

